\title{
$\mathrm{RO̊̊M}$ \\ Royal Ontario Museum
}
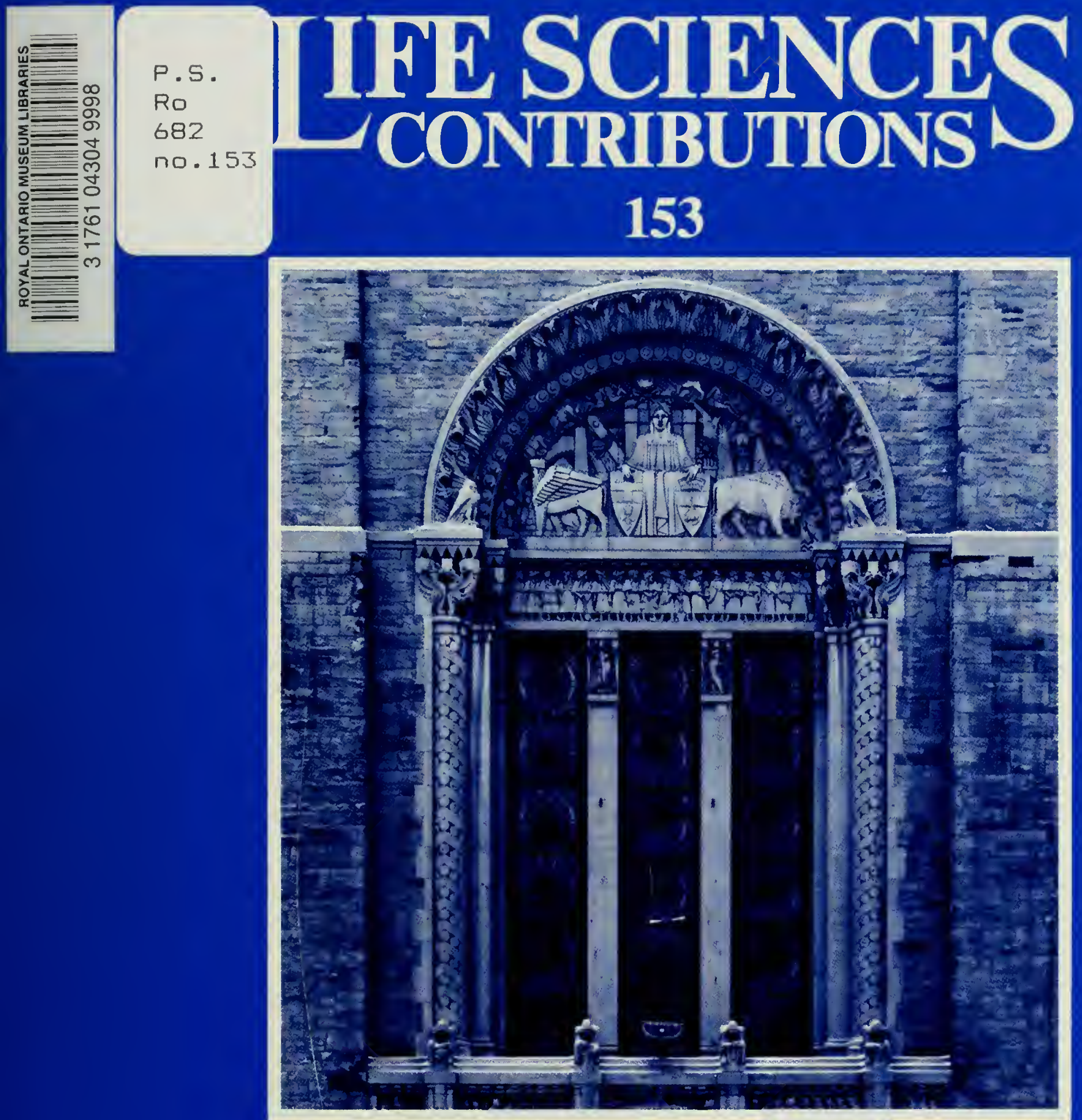

\section{Silurian Trilobites from the Northern Yukon Territory}

Rolf Ludvigsen and Ronald P. Tripp 


\section{ROYAL ONTARIO MUSEUM LIFE SCIENCES PUBLICATIONS INSTRUCTIONS TO AUTHORS}

Authors should prepare their manuscripts carefully according to the following instructions; failure to do so will result in the manuscript's being returned to the author for revision. All manuscripts are considered on the understanding that they are not currently offered for publication elsewhere.

1. General Papers for publication are accepted from ROM staff members and research associates, and from researchers reporting on work done with ROM collections. Monographs on the flora and/or fauna of Ontario may be considered for publication by authors not affiliated with the ROM. Financial contributions towards publication will be welcome. Authors are expected to write clearly and concisely and to omit any material not essential for an understanding of the main theme of the paper.

2. Format Manuscripts (including captions, synonymies, literature cited, and tables) should be typed with double space on $11^{\prime \prime} \times 8 \frac{1}{2}$ " paper with a $1 \frac{1}{2}$ " margin on all sides. Three xerox copies should be submitted to the Senior Editor of the Editorial Board; the original should be retained by the author(s). The submission should include a separate sheet giving the author(s) names and affiliations, the title of the publication, the series for which it is submitted, the number of typed pages, the number of tables, and the number of plates or figures. Manuscripts should normally be organized in the following order: Contents, Abstract, Introduction, Materials and Methods, Results, Discussion, Conclusions, Summary (if manuscript is long), Acknowledgements, Appendices, and Literature Cited. Authors are encouraged to include foreign-language translations of the Summary, if appropriate. Main headings should be centred; subheadings should be left-justified to the text margin. The first line of the first paragraph in each new section should not be indented. Literature citations in the text should be in the form "Jones (1972)" or "(Jones, 1972)" or "(Smith, 1960:71-79, fig. 17)".

3. Standard Sources The primary authority on questions of format and style is Guide to Authors, available from ROM Publication Services. For matters not covered in the Guide, consult CBE Style Manual (Fifth Edition). Other standard sources are as follows: for
English spelling, The Concise Oxford Dictionary; for Canadian place names and coordinates, Canada Gazetteer Atlas; for the spelling of geographic names, The Times Atlas.

4. Abstract All papers must be preceded by a short, factual abstract, about one per cent of the text in length. The abstract may be followed by four to six key words in parentheses.

5. Taxonomy The name of a taxon should be given in full in headings, at the beginnings of paragraphs, and at its first occurrence in the text. Give the authority and date, if appropriate, with the first mention of each taxon, but not thereafter. Taxonomic papers, particularly synonymies, should follow the layout in Life Sciences Contributions beginning with No. 136. International Codes of Biological Nomenclature must be followed.

6. Literature Cited A complete list of references, in alphabetical order of authors, must be given at the end of the paper. When two or more works of one author are cited, they should be listed chronologically. The names of journals should not be abbreviated. For correct bibliographic form, see Life Sciences Contributions beginning with No. 136 .

7. Tables All tables should be typed on separate sheets and numbered consecutively in arabic numerals in the order of their first mention in the text. Mark the location of each table in the margin of the text.

8. Plates, Figures, and Text-figures Illustrations may be designated according to the conventions of the author's discipline; in some disciplines grouped photographs of scientific subject matter are commonly termed Plates, while line drawings and locality and other illustrations that occupy a full page or less are Text-figures. Usage must be consistent throughout the paper. A full-page illustration for a Contribution, with its caption, should be sized to fit an area of $17.3 \times$ $22.75 \mathrm{~cm}$; for Occasional Papers, the area is $14.1 \times$ $21.2 \mathrm{~cm}$. If captions are lengthy, they may be placed on the facing page. A scale or magnification factor should be included. Authors are reminded that when illustrations are reduced magnification factors will change, and that they are responsible for the conversion. For details, see Guide to Authors.

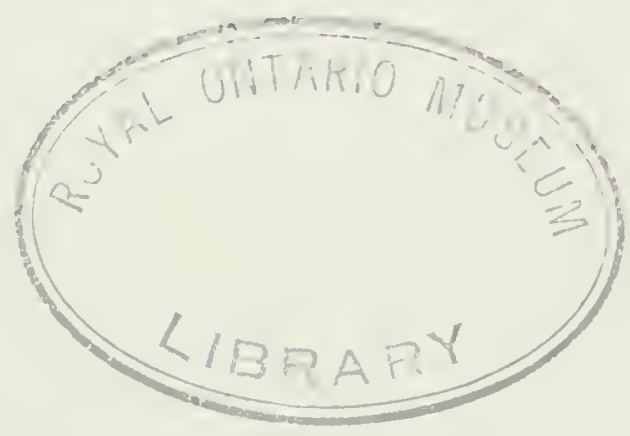




\title{
Silurian Trilobites from the Northern Yukon Territory
}

\author{
Rolf Ludvigsen \\ and \\ Ronald P. Tripp
}

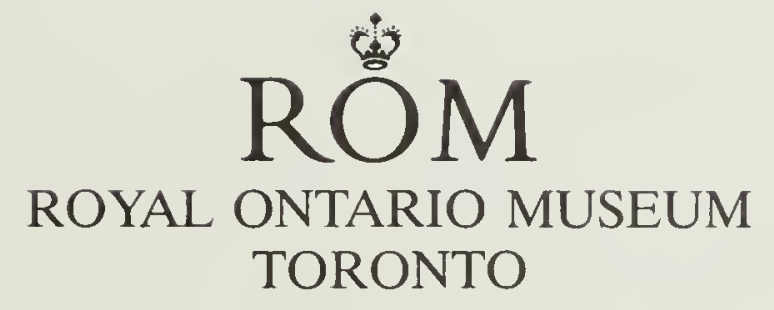


ROYAL ONTARIO MUSEUM

PUBLICATIONS IN LIFE SCIENCES

The Royal Ontario Museum publishes three series in the Life Sciences: CONTRIBUTIONS: a numbered series of original scientific publications.

OCCASIONAL PAPERS: a numbered series of original scientific publications, primarily short and of taxonomic significance.

MISCELLANEOUS PUBLICATIONS: an unnumbered series on a variety of subjects.

All manuscripts considered for publication are subject to the scrutiny and editorial policies of the Life Sciences Editorial Board, and to independent refereeing by two or more persons, other than Museum staff, who are authorities in the particular field involved.

\section{LIFE SCIENCES EDITORIAL BOARD}

Senior editor: D. C. Darling

Editor: R. W. Murphy

Editor: J. H. McAndrews

External editor: C. S. Churcher

Manuscript editor: E. J. Crossman

Production editor: J. E. Hawken

Rolf Ludvigsen is research associate, Department of Invertebrate Palaeontology, Royal Ontario Museum, Toronto, and head of the Denman Institute for Research on Trilobites, 4062 Wren Road, Denman Island, British Columbia V0R 1T0.

Ronald P. Tripp is also research associate, Department of Invertebrate Palaeontology, Royal Ontario Museum, Toronto. He currently resides at 41 Kirk Drive, Thornhill, Ontario L3T 3K8.

\footnotetext{
Canadian Cataloguing in Publication Data

Ludvigsen, Rolf, 1944-

Silurian trilobites from the northern Yukon Territory

(Life sciences contributions, ISSN 0384-8159; 153)

Includes bibliographical references.

ISBN 0-88854-349-2

1. Trilobites. 2. Paleontology - Silurian.

3. Paleontology - Yukon Territory. I. Tripp, Ronald

P. (Ronald Pearson), 1914- . II. Royal Ontario Museum. III. Title. IV. Series.
}

\section{QE821.L83 I989 565'.393'097191 C89-09501I-3}

Publication date: 1 February 1990

ISBN 0-88854-349-2

ISSN 0384-8159

(C) Royal Ontario Museum, 1989

100 Queen's Park, Toronto, Canada M5S 2C6

PRINTED AND BOUND IN CANADA BY GAGNÉ PRESS

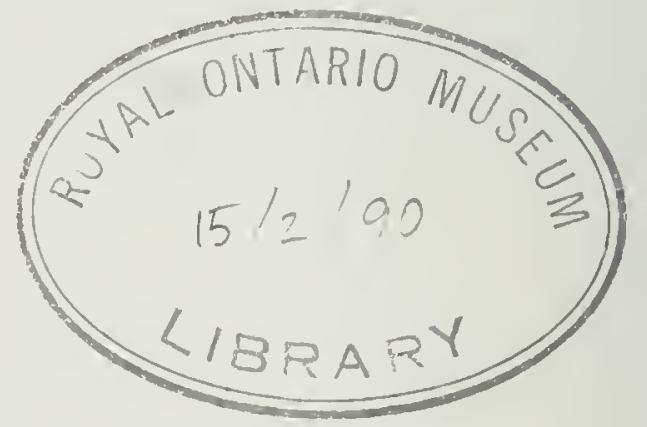




\section{Contents}

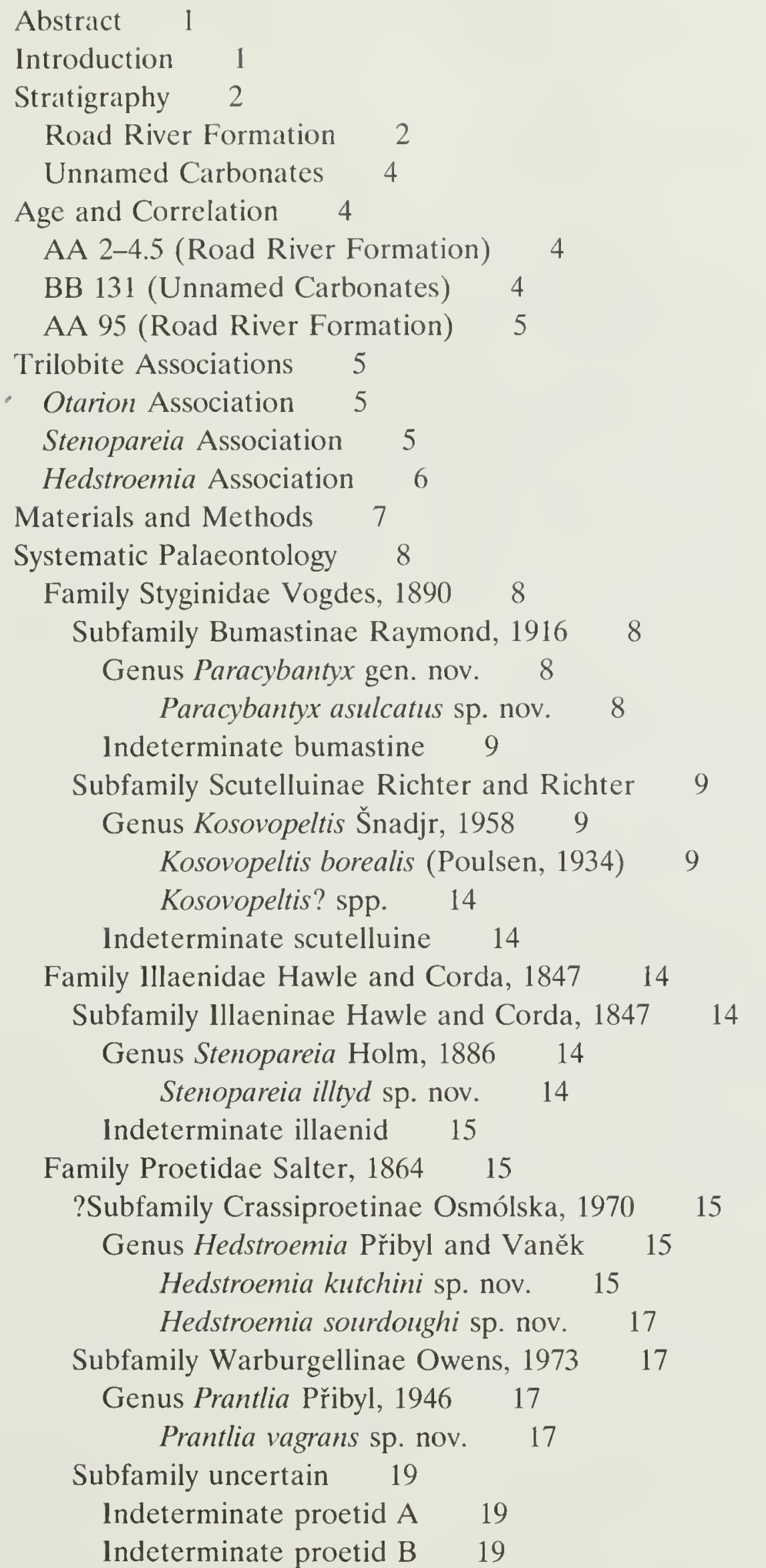

Family Aulacopleuridae Angelin, $1854 \quad 20$

Genus Otarion Zenker, 183320

Subgenus Songkania Chang, 197420

Otarion (Songkania) socialis (Poulsen, 1934) 20

Family Harpidae Hawle and Corda, 184721

Genus Scotoharpes Lamont, 194821

Scotoharpes raaschi Norford, $1973 \quad 21$ 
Family Cheiruridae Hawle and Corda, I847 22

Subfamily Cheirurinae Hawle and Corda, 1847

Genus Cheirunus Beyrich, 184522

Cheirurus sp. 22

Family Encrinuridae Angelin, 185422

Subfamily Encrinurinae Angelin, $1854 \quad 22$

Genus Cromus Barrande, $1852 \quad 22$

Cromus princeps (Poulsen, 1934) 22

Genus Encrinuraspis Webby, Moors, and McLean, 1970

Encrinuraspis sp.

24

Genus Balizoma Holloway, 198024

Balizoma aff. B. obtusus (Angelin, 1851)

24

Indeterminate encrurine $\quad 25$

Family Calymenidae Milne-Edwards, $1840 \quad 26$

Subfamily uncertain 26

Indeterminate calymenid 26

Family Lichidae Hawle and Corda, 184726

Subfamily Lichinae Hawle and Corda, 184726

Genus Dicranopeltis Beyrich, $1845 \quad 26$

Dicranopeltis sp. 26

Subfamily uncertain 26

Indeterminate lichid 26

Family Odontopleuridae Burmeister, $1843 \quad 27$

Subfamily Odontopleurinae Burmeister, $1843 \quad 27$

Genus Leonaspis Richter and Richter, $1917 \quad 27$

Leonaspis semiglabra (Poulsen, 1934) 27

Indeterminate odontopleurine $\quad 28$

Acknowledgements 29

Literature Cited $\quad 30$

Plates 34 


\title{
Silurian Trilobites from the Northern Yukon Territory
}

\begin{abstract}
Silurian trilobites are described from two contrasting facies in the northern Yukon Territory: basinal sediments of the Road River Formation at Prongs Creek and shallow-water limestones of the Illtyd Range. An Otarion Association from dark grey, argillaceous lime mudstones (Lower Silurian) consists of Kosovopeltis, Otarion (Songkania), Cromus, and Leonaspis. These trilobites are identical to those described by Poulsen (1934) from his Cape Schuchert Formation of North Greenland. A Stenopareia Association from off-white biosparites (Lower Silurian) includes Stenopareia, a bumastine, Kosovopeltis, and Scotoharpes. A Hedstroemia Association occurs in an Upper Silurian debris flow. It includes Hedstroemia, Prantlia, Balizoma, and Paracybantyx.

An incomplete ontogeny of Kosovopeltis borealis (Poulsen) comprises a protaspis and four different transitory pygidia.

The bumastine genus Paracybantyx is new. New species are Paracybantyx asulcatus, Stenopareia illtyd, Hedstroemia kutchini, H. sourdoughi, and Prantlia vagrans.
\end{abstract}

\section{Introduction}

Silurian rocks crop out as two contrasting facies in the northern Yukon Territory: as basinal shales of the Road River Formation within the Richardson and Blackstone troughs in the Peel River-Wind River area (Lenz, 1972), and as thick-bedded to massive carbonates, yet unnamed, on the Mackenzie Platform in the Bonnet Plume River area and on the Yukon Block in the Porcupine River area (Text-fig. 1). In the basinal shales exceptionally complete stratigraphic successions of graptolites are present (Lenz and Pedder, 1972; Lenz, 1982), but in the platform carbonates well-preserved fossils of Silurian age are uncommon, with the exception of locally abundant tabulate corals and pentamerid brachiopods. The best-preserved and mostdiverse assemblages of Silurian shelly fossils in the Yukon Territory are found in dark grey, argillaceous limestones deposited on the margins of the troughs, close to facies transitions with shallow-water carbonates in areas along the Wind River such as Prongs Creek (Raasch, Norford, and Wilson, 1961; Lenz, 1970) and Royal Creek (Lenz, 1977; Jackson, Lenz, and Pedder, 1978). These assemblages are strongly dominated by brachiopods, but a few include substantial numbers of trilobites of types that are either unknown from northern Canada or incompletely documented.

Rich Silurian trilobite assemblages have been described from the Whittaker and Delorme formations farther to the south in the Mackenzie Mountains of the District of Mackenzie (Perry and Chatterton, 1977; Chatterton and Perry, 1983), and smaller assemblages have been described from different localities to the north in the Canadian Arctic Islands (Bolton, 1965; Perry and Chatterton, 1977; Thomas and Narbonne, 1979) and North Greenland (Poulsen, 1934; Lane, 1979, 1984; Lane and Owens, 1982). In the Yukon Territory, however, Silurian trilobites have been documented from only two Lower Silurian localities-one from dark grey limestones of the Road River Formation at Prongs Creek (Raasch, Norford, and Wilson, 1961) and one from off-white limestone in the nearby Illtyd Range (Norford, 1973). In this paper, we reevaluate and describe fully both these trilobite assemblages on the basis of larger and more complete collections than were available to previous investigators. We also deal with a new trilobite fauna from the Upper Silurian part of the Road River Formation on Prongs Creek. 


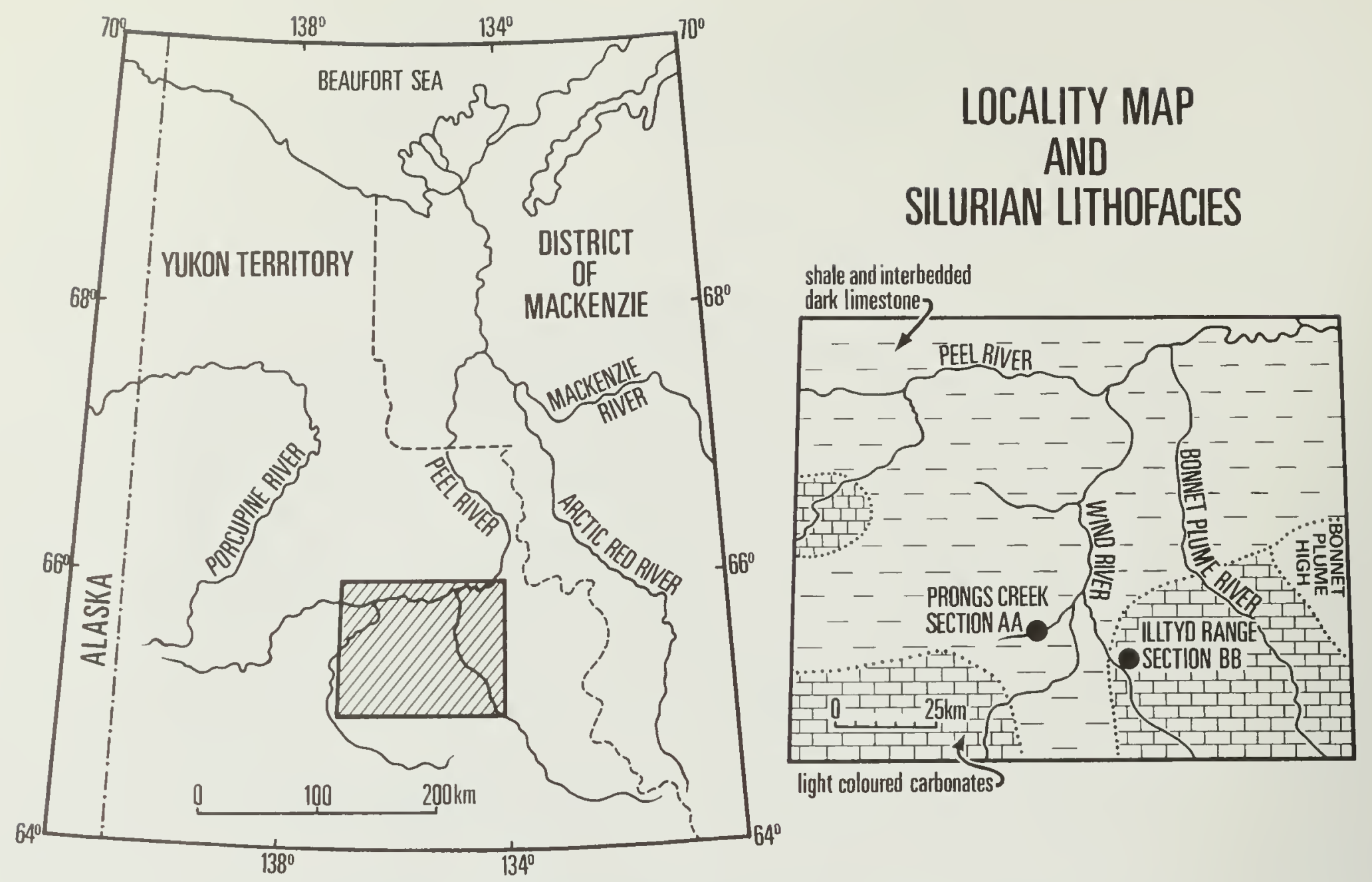

TEXT-FIG. 1. Locality map of the northern Yukon Territory showing Section AA on Prongs Creek and Section BB in the Illtyd Range. The generalized Silurian lithofacies map is adapted from Lenz (1972, fig. 9).

\section{Stratigraphy}

\section{ROAD RIVER FORMATION}

The Road River Formation was raised to group status by Fritz (1985), who considered four undesignated map units in the Richardson Mountains to constitute formations. Until such time as these map units are defined and formally named, we retain the formational status of the Road River. Within the Richardson Trough north of the Pecl River, the Road River Formation consists of more than one thousand metres of shales, cherts, and limestones of Cambrian, Ordovician, Silurian, and Devonian age. The axis of this intracratonic trough swings east along the Bonnet Plume River to join the Selwyn Trough to the south (Lenz, 1979, fig. 1; Norris, 1985:40). During the Silurian, a narrow northsouth embayment off the Richardson Trough developed near the headwaters and along the tributaries of the Wind River. Here, the Road River Formation comprises a recessive sequence of calcareous shales and argillaceous limestones which rests abruptly on resistant Ordovician carbonates (see Lenz, 1972, fig. 8; Norris, 1985, fig. 10). On Prongs Creek, the lower con- tact of the Road River is concordant, but apparently disconformable because Upper Ordovician (Richmondian; Norford, 1964) strata are followed directly by mid-Lower Silurian strata. Unconformities of similar magnitude occur at the same interval in shelf successions of most other areas of western North America (Lenz, 1976).

Starting about $50 \mathrm{~m}$ above its base on Prongs Creek (Text-fig. 2), the Road River Formation begins to display evidence of relief associated with nearby carbonate banks. Contorted bedding, slumps, and thick debris flows consisting of jumbled fossils and small lithoclasts become common. The debris flows were probably derived from the flanks of shallow carbonate banks such as those now exposed in the llltyd Range to the east or near the headwaters of the Hart River to the southwest.

Sample AA 2-4.5 was obtained from medium-bedded, highly argillaceous lime mudstones of deep-water aspect, at the base of the Road River Formation. Sample AA 95 was collected from a prominent 2-m-thick 


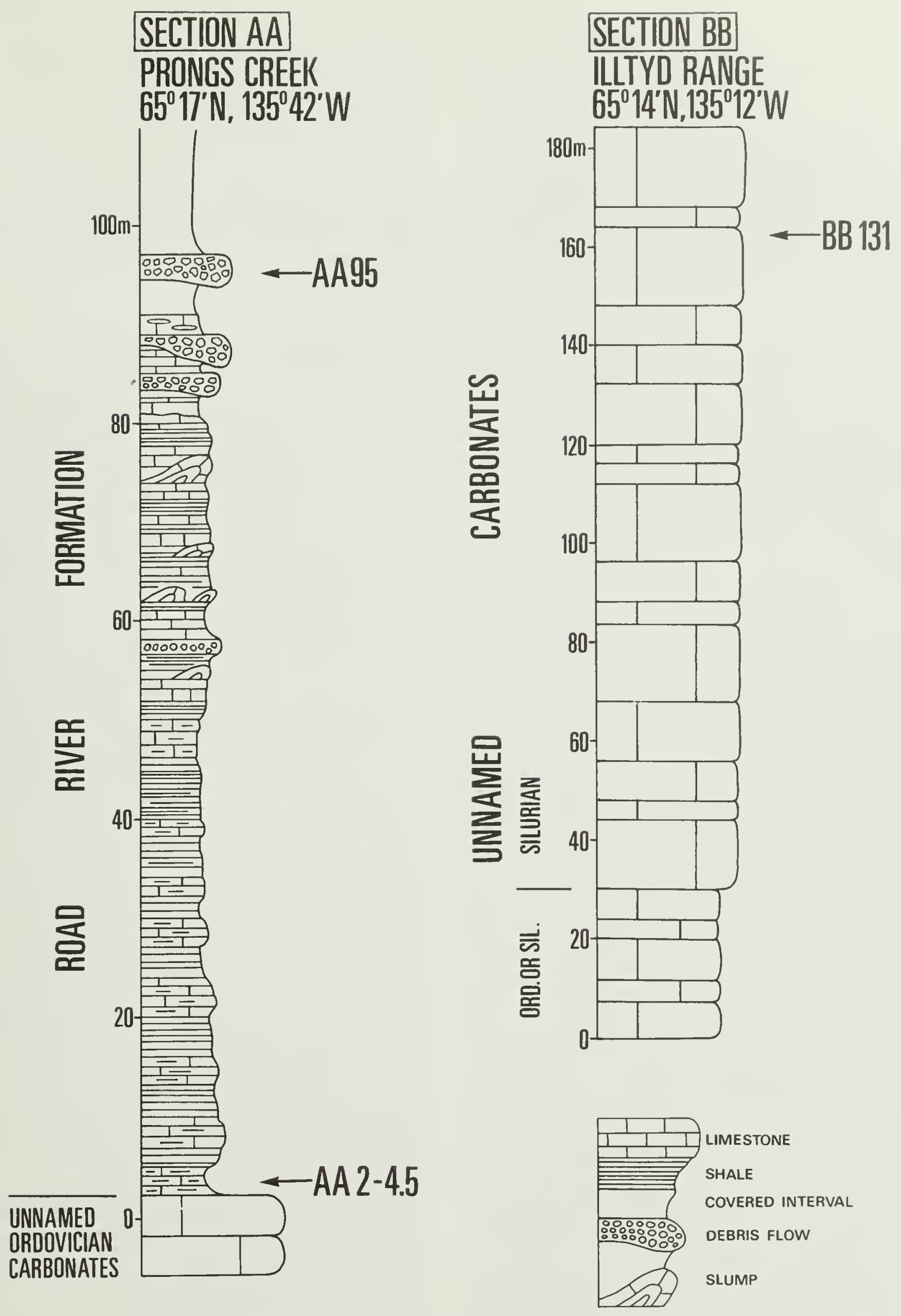

TEXT-FIG. 2. Graphic lithological $\log$ of Section AA, through the lower part of the Road River Formation on Prongs Creek, and of Section BB, through unnamed Ordovician and Silurian carbonates in the Illtyd Range. Sample BB 131 was collected $131 \mathrm{~m}$ above the base of massive and resistant Silurian limestones, that is, at unit 3 of Norford's (1964) Section 5. 
debris flow located $95 \mathrm{~m}$ above the base of the formation.

\section{UNNAMED CARBONATES}

The llltyd Range exposes a thick sequence of poorly fossiliferous, thick-bedded to massive, shallow-water limestones of probable Ordovician, Silurian, and Devonian age (Norford, 1964; Lenz, 1972; Norris, 1985).
This carbonate bank maintained itself while sediments of the Road River Formation accumulated in the Richardson Trough farther to the north.

Norford (1964:36) measured a distinctive unit 3 of the unnamed carbonates consisting of $200 \mathrm{~m}$ of massive, crystalline off-white limestone, which weathers into steep pinnacles; Norford's unit 3 is probably entirely of Early Silurian age. Sample BB 131 was collected $131 \mathrm{~m}$ above the base of this unit.

\section{Age and Correlation}

\section{AA 2-4.5 (ROAD RIVER FORMATION)}

Raasch, Norford, and Wilson (1961) described brachiopods, trilobites, and graptolites from samples collected at unspecified levels across a 50 -m interval, starting at the top of the resistant Ordovician carbonates at the gorge of Prongs Creek. These samples included a trilobite fauna with Aulacopleura socialis, herein referred to as Otarion (Songkania) socialis and identical to the fauna from our sample AA 2-4.5, as well as a graptolite fauna representing the Lower Silurian Monograptus turriculatus Zone. A measured section in Norford $(1964: 49,127)$ located the $O$. $(S$. $)$ socialis fauna in the lower $6 \mathrm{~m}$ of the Road River Formation on Prongs Creek, the $M$. turriculatus Zone a few metres higher, followed by the $M$. spiralis Zone some 10 to $21 \mathrm{~m}$ upsection.

Both Raasch, Norford, and Wilson (1961) and Norford (1964) indicated a late Llandovery age for the Otarion fauna on Prongs Creek based on its position relative to the position of the $M$. turriculatus Zone. This age assessment receives support from an abundant, but low-diversity, conodont fauna from sample AA 2-4.5. According to Godfrey Nowlan of the Geological Survey of Canada (pers. comm., 1987), the sample is dominated by "Oulodus" fluegeli (Walliser) and includes Dapsilodus obliquicostatus, Ozarkodina excavata excavata, Panderodus gracilis, and Walliserodus sancticlair. Nowlan noted that, in other parts of the Yukon Territory, "O." fluegeli is common in strata bearing graptolites of the M. turriculatus Zone and further suggested that this association of conodont elements probably represents a deep-water biofacies.

Raasch (in Raasch, Norford, and Wilson, 1961) recognized that the four species of trilobites comprising the $O$. (S.) socialis fauna on Prongs Creek are identical to those described by Poulsen (1934), which had been collected by Lauge Koch from different localities of the Cape Schuchert Formation in Washington Land, North Greenland. These trilobites must have been conspicuous elements of the Cape Schuchert Formation because
Koch had previously referred these strata to the "Arethusina (= Aulacopleura) beds" (see Dawes and Haller, 1979; Hurst, 1980:74).

There is considerable uncertainty about the provenance of the Otarion fauna in North Greenland. The Silurian stratigraphic framework of Washington Land was revised by Hurst (1980), who restricted Koch's Cape Schuchert Formation to black bituminous lime mudstones of Llandovery age; the overlying shales and mudstones were assigned to the Lafayette Bugt Formation of middle Llandovery to Ludlow age. Koch's locality data were definitely generalized and possibly unreliable (Norford, 1972:9). Apparently Otarion occurs in both formations, but neither Norford (1972) nor Hurst (1980) located this trilobite in Lower Silurian stratigraphic sections of Washington Land. It is known with certainty from only a single stratigraphically located collection in North Greenland. According to John S. Peel of the Greenland Geological Survey, $O$. (S.) socialis and Cromus princeps occur in GGU sample 216841, collected from Norford's (1972:13) unit 4, which is overlain (in unit 6) by graptolites of the $M$. turriculatus Zone. These rock units were assigned to the Cape Phillips Formation by Norford (1972) and to the Lafayette Bugt Formation by Hurst (1980).

In summary, trilobite collection AA 2-4.5, with Otarion (Songkania), Kosovopeltis, Cromus, and Leonaspis from the lowest Road River Formation on Prongs Creek, is Early Silurian in age and equivalent to, or slightly older than, the $M$. turriculatus Zone. A faunule with Otarion (Songkania) and Cromus from the Lafayette Bugt Formation near Kap Schuchert in North Greenland is approximately the same age.

\section{BB 131 (UNNAMED CARBONATES)}

Norford $(1964,1973)$ recorded a sparse trilobite fauna of Scotoharpes raaschi Norford, Encrinurus cf. E. princeps Poulsen, Scutellum sp., and an illaenid at GSC locality 53109 from a 1-m interval $425 \mathrm{~m}$ above the base 
of an unnamed carbonate unit in the Illtyd Range; he dated this fauna as late Llandovery. This interval of massive, off-white, coarsely crystalline biosparite, located $131 \mathrm{~m}$ above the base of Norford's unit 3, was re-collected as locality $\mathrm{BB} 131$. A meagre conodont fauna of 14 fragmentary specimens, including ?"Oulodus" fluegeli, Panderodus gracilis, and Walliserodus sp., was identified by G. Nowlan (pers. comm., 1987), who suggested that it was probably of late Llandovery age.

\section{AA 95 (ROAD RIVER FORMATION)}

Lenz (1970) described a moderately rich fauna of Late Silurian brachiopods from a thick limestone bed located $106 \mathrm{~m}$ above the base of the Road River Formation on Prongs Creek. Re-collection of this bed yielded a large number of well-preserved trilobites. According to Ludvigsen's measured section, this bed is located
$95 \mathrm{~m}$ above the base of the formation; therefore, our sample is designated AA 95. On the basis of graptolite faunas below and above, Lenz (1970) correlated the fossiliferous bed with either the latest Ludlow or the earliest Pridoli, an age assignment consistent with biostratigraphic information from a meagre conodont fauna. Later Jackson, Lenz, and Pedder (1978:20) assigned the overlying graptolite collection to the Monograptus formosus Zone, which in central Europe comprises the basal zone of the Pridoli.

The trilobite fauna from AA 95 consists largely of new species and, therefore, contributes little information toward an age assignment and correlation of this unit. We tentatively correlate AA 95 with the upper Ludlow on the basis of the overlying graptolites. The trilobites, in particular Prantlia vagrans sp. nov. and Balizoma aff. B. obtusus (Angelin), have greater affinities to Ludlow than to Pridoli species.

\section{Trilobite Associations}

Each of the three samples of Silurian trilobites from the northern Yukon Territory dealt with here is dominated numerically by a different family (Text-fig. 3, Table 1), and each association clearly owes its composition to environmental factors (see also Ludvigsen et al., 1986).

\section{OTARION ASSOCIATION}

Because of its size, Kosovopeltis is the most conspicuous trilobite in sample AA 2-4.5, but the association is named for Otarion which, though small, is numerically dominant. The Otarion Association occurs in dark grey, highly argillaceous lime mudstones of the lower few metres of the Road River Formation at Prongs Creek, in association with a low-diversity brachiopod fauna (Norford, in Raasch, Norford, and Wilson, 1961). The strata appear to be of deep-water aspect, a setting that receives support from the low diversity of the trilobite fauna and from the association of conodont elements (G. Nowlan, pers. comm., 1987).

Aulacopleurids typically constitute minor elements of trilobite associations in off-platform graptolite shale basins (for example, Thomas, 1979, fig. 2), but we are not aware of any published account of another trilobite assemblage such as the Otarion Association that is dominated by an aulacopleurid.

\section{STENOPAREIA ASSOCIATION}

A small collection from locality BB 131 is dominated by Stenopareia and an indeterminate bumastine. It came from an interval of off-white crystalline biosparite in the Lower Silurian part of an unnamed unit in the Illtyd Range; this unit records shallow-water carbonate bank deposition during most of the Silurian and Early Devonian (Text-fig. 1). The Stenopareia Association shows no evidence of transportation and is, presumably, autochthonous. This association in the Illtyd Range is very similar to that described by Lane (1979) from white, coarsely crystalline limestones of the upper part of the Alequatsiad Fiord Formation (mid-Llandovery) near Kap Schuchert, North Greenland, which also is dominated by Stenopareia and bumastines.

The Early Silurian Stenopareia Association of the Yukon Territory and Greenland is clearly part of the illaenid-cheirurid associations that also occur widely in Ordovician carbonate build-ups and in subtidal shelf settings in other areas of Laurentia (Westrop, 1983). The Stenopareia Association itself seems to be a shelf assemblage; it differs from contemporaneous build-up assemblages in, for example, the Pentamerus Bjerg Formation of North Greenland, which is dominated by a proetine and a scutelluine (Lane and Owens, 1982), or the Hopkinson Dolomite of Iowa, which is characterized by a lichid and a cheirurid (Mikulic, 1981).

Within the limits of correlation possible using conodont biostratigraphy of the Road River Formation on Prongs Creek and of unnamed carbonates of the Illtyd Range, the Otarion Association from dark grey, argillaceous lime mudstones is of the same age as the higherdiversity Stenopareia Association from off-white biosparites. 


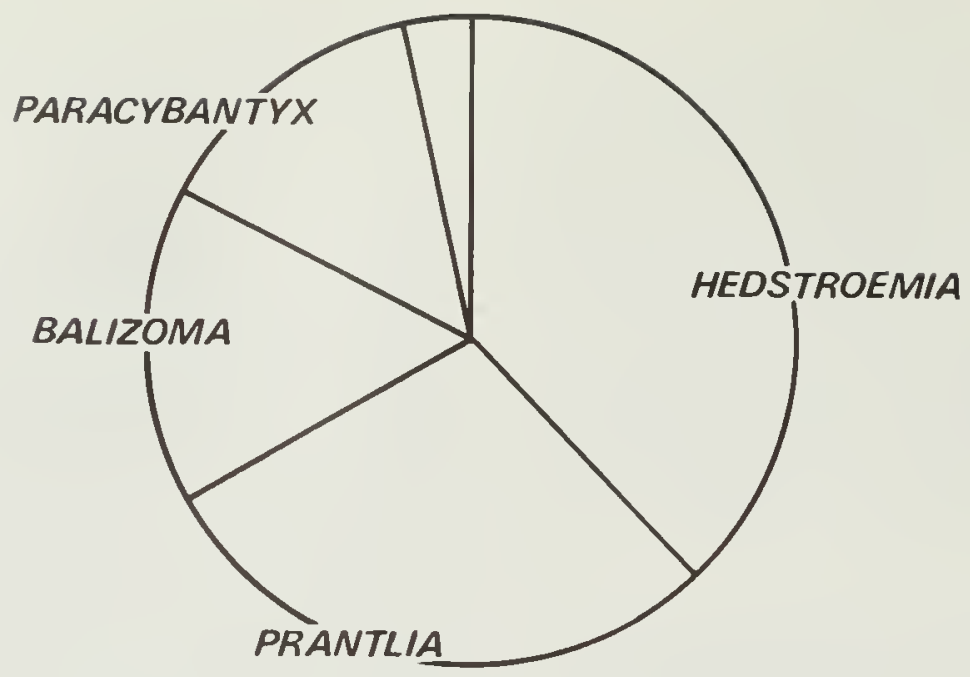

AA 95

HEDSTROEMIA ASSOCIATION

UPPER SILURIAN

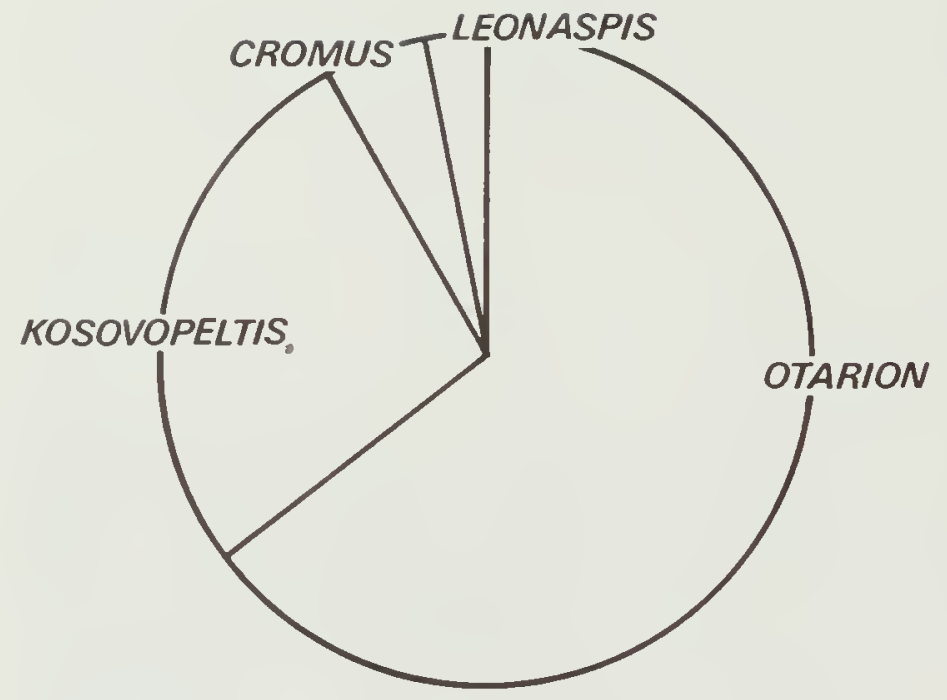

AA2-4.5

OTARION ASSOCIATION

$n=420$

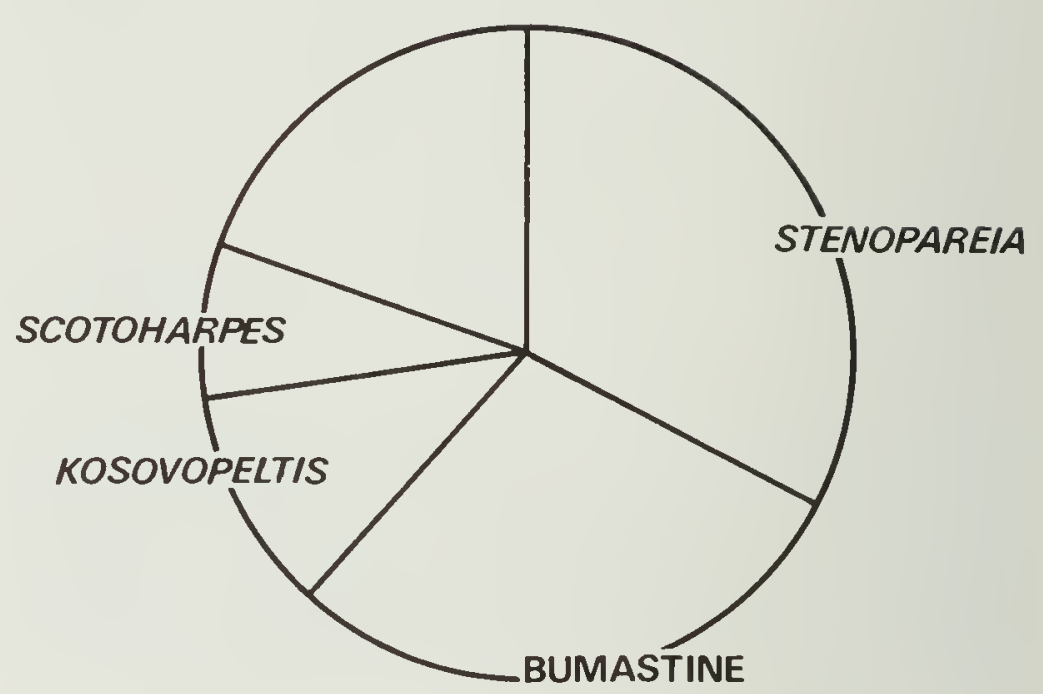

BB 131

\section{LOWER SILURIAN}

STENOPAREIA ASSOCIATION

TEXT-FlG. 3. Pic diagrams showing generic relative abundance of specimens in the three trilobite associations dealt with in this study.

\section{HEDSTROEMLA ASSOCIATION}

A 2-m-thick debris flow in the Upper Silurian part of the Road River Formation on Prongs Creek yielded a diverse brachiopod fauna of 17 species, dominated numerically by the smooth atrypoid Cryptatrypa (Lenz, 1970), and a trilobite assemblage of 7 species that we name the Hedstroemia Association. About two-thirds of the specimens in this association belong to 3 proetine and warburgelline species; the remaining specimens are bumastines, encrinurids, and lichids.

The debris flows display scoured bases and lack internal grading. They appear to be the products of slumps that swept shells and small (less than $1 \mathrm{~cm}$ ) limestone clasts off the sides of the adjoining carbonate banks and into the centre of the shale embayment (see also
Lenz, 1977).

The Hedstroemia Association is different from the few Upper Silurian trilobite faunas described from northern Canada to date. Faunas from shallow subtidal settings in the Road River Formation on Cornwallis Island in the Canadian Arctic appear to be dominated by the warburgelline Helokybe, the encrinurid Encrinurus, and the lichid Hemiarges (Thomas and Narbonne, 1979).

The dominance of proetines and warburgellines in the Hedstroemia Association is matched by the Proetus/ Warburgella Association from shelf limestones of the British Wenlock (Thomas, 1979), but that association shows considerably higher generic diversity. 
TABLE 1. Summary of frequencics.

comp., complete; cran., cephala/cranidia; hypo., hypostomes; pyg., pygidia; total, number of specimens of the most frequent part; $\%$, percentage of the total number of specimens.

\begin{tabular}{|c|c|c|c|c|c|c|}
\hline Species & comp. & cran. & hypo. & pyg. & total & $\%$ \\
\hline Lower Silurian & & & & & & \\
\hline AA 2-4.5, Prongs Creek & \multicolumn{6}{|c|}{ Otarion Association } \\
\hline Kosovopeltis borealis & 2 & 78 & 19 & 116 & 116 & 27 \\
\hline Otarion (Songkania) socialis & 7 & 270 & 3 & 78 & 270 & 65 \\
\hline Cromus princeps & 1 & 10 & 4 & 23 & 23 & 5 \\
\hline Leonaspis semiglabra & 1 & 8 & 4 & 11 & 11 & 3 \\
\hline BB 131, Illtyd Range & \multicolumn{6}{|c|}{ Stenopareia Association } \\
\hline Kosovopeltis? spp. & - & 1 & - & 3 & 3 & 11 \\
\hline Indeterminate bumastine & - & 8 & - & 1 & 8 & 29 \\
\hline Stenopareia illtyd sp. nov. & - & 9 & - & 6 & 9 & 32 \\
\hline Indeterminate illaenid & - & 1 & - & - & 1 & 3 \\
\hline Indeterminate proetid B & - & 1 & 1 & 1 & 1 & 3 \\
\hline Scotoharpes raaschi & - & 2 & - & - & 2 & 7 \\
\hline Cheinunes sp. & - & 1 & - & 1 & 1 & 3 \\
\hline Encrinuraspis sp. & - & - & - & 1 & 1 & 3 \\
\hline Indeterminate calymenid & - & - & - & 1 & 1 & 3 \\
\hline Dicranopeltis sp. & - & 1 & - & 1 & 1 & 3 \\
\hline Indeterminate odontopleurine & - & 1 & - & - & 1 & 3 \\
\hline
\end{tabular}

\section{Upper Silurian}

AA 95, Prongs Creek

Paracybantyx asulcatus gen. et sp. nov.

Indeterminate scutelluine

Hedstroemia kutchini sp. nov.

Hedstroemia sourdoughi sp. nov.

Prantlia vagrans sp. nov.

Indeterminate proetid $\mathrm{A}$

Balizoma aff. B. obtusus

Indeterminate encrinurine

Indeterminate lichid

\begin{tabular}{lrrrrr}
\multicolumn{7}{c}{ Hedstroemia } & Association \\
- & 19 & 2 & 24 & 24 & 14 \\
- & 1 & - & - & 1 & 1 \\
- & 9 & 2 & 40 & 40 & 23 \\
- & 8 & - & 25 & 25 & 14 \\
- & 16 & - & 48 & 48 & 28 \\
- & - & 1 & - & 1 & 1 \\
- & 5 & 1 & 27 & 27 & 15 \\
- & 1 & - & - & 1 & 1 \\
- & 3 & 5 & 5 & 5 & 3
\end{tabular}

\section{Materials and Methods}

All the figured specimens that were collected have been deposited at the Royal Ontario Museum; their registered numbers bear the prefix ROM. Other specimens illustrated are in the collection of the Geological Survey of Canada, Ottawa, and are prefixed GSC.

As far as possible, plates are arranged in the order of the systematic section. Upper Silurian trilobites from AA 95 constitute Plates 1, 6, 7, 11. Lower Silurian trilobites from AA 2-4.5 constitute Plates 2-4, 8, 10, 12; Plate 4 comprises scanning electron micrographs prepared at the University of Toronto. Lower Silurian trilobites from BB 131 constitute Plates 5 and 9. Plate 13 comprises photographs of plaster casts of Poulsen's (1934) original specimens from North Greenland. Originals are housed in the Mineralogical and Geological Museum, University of Copenhagen (MMH).

The terminology used is essentially that defined by Harrington, Moore, and Stubblefield (in Moore, 1959:117-126). Glabellar lobes, furrows, and muscle impressions are numbered from back to front and symbolized by $\mathrm{L}, \mathrm{S}$, and $\mathrm{G}$, respectively. The occipital ring is regarded as part of the glabella. 


\title{
Systematic Palaeontology
}

\author{
Family Styginidae Vogdes, 1890
}

\section{DISCUSSION}

Lane and Thomas (1983:141) have argued that numerous genera previously referred to separate families and subfamilies of effaced trilobites should be included in an undivided family Styginidae. In this paper we prefer to continue the use of the subfamilies Stygininae, Scutelluinae, and Bumastinae as an aid to grouping the large number of genera in the family.

\section{Subfamily Bumastinae Raymond, 1916}

\section{Genus Paracybantyx gen. nov.}

\section{DERIVATION OF NAME}

Name derived from Latin para (beside) and Cybantyx. Gender masculine.

\section{DIAGNOSIS}

Cranidium broad, lacking anterior border and furrow. Axial furrow bowed inward, faint posteriorly. Pygidium convex, 85 to 100 per cent as wide as long, effaced. Surface finely pitted.

\section{TYPE SPECIES}

Paracybantyx asulcatus sp. nov., locality AA 95 (Upper Silurian), Road River Formation, Prongs Creek, Yukon Territory, Canada.

\section{OTHER SPECIES}

None.

\section{DISCUSSION}

The absence of the anterior border and furrow precludes inclusion of this species in the genus Cybantyx, Lane and Thomas (in Thomas, 1978), which it otherwise resembles.

\section{Paracybantyx asulcatus sp. nov.}

Pl. 1, figs. 1-15; Pl. 11, figs. 1-5

\section{DERIVATION OF NAME}

Specific name derived from Latin $a$ (without) and sulcatus (furrowed), referring to the absence of the anterior border furrow.

\section{HOLOTYPE}

ROM 45344 (cranidium, Pl. 1, figs. 4,5), locality AA 95 (Upper Silurian), Road River Formation, Prongs Creek, Yukon Territory, Canada.

\section{DIAGNOSIS}

As for genus.

\section{MATERIAL}

From AA 95 (Upper Silurian), Prongs Creek: 19 cranidia, 4 librigenae, 2 hypostomes, 24 pygidia.

\section{DESCRIPTION}

Cranidium 85 to 95 per cent as long as wide, longitudinal curvature strongest toward front, evenly convex transversely, broadly rounded in outline anteriorly. Glabella wide, narrowest opposite palpebral lobe where it occupies two-thirds width between margins, widening forward and backward. Small tubercle near posteromedian margin. Occipital ring and furrow effaced. Axial furrow broad and shallow at back, deepening forward, bowed more or less strongly inward, terminating in large, rounded anterior pit opposite onetenth cranidial length from front. On larger specimens, axial furrow effaced anteriorly and posteriorly. Genal muscle impression alongside axial furrow on fixigena almost one-fifth length of cranidium, situated at own length anterior to posterior margin; outline of impression running parallel to that of palpebral lobe. Palpebral lobe slightly swollen and gently rounded in outline, one-quarter length of cranidium, with posterior extremity opposite that of lateral muscle impression. Anterior border and furrow absent. Anterior branch of facial suture running outward, parallel to axial furrow at first, and then curving forward and inward; posterior branch directed backward and slightly outward. Cranidium faintly pitted, with faint terrace ridges running parallel to anterior margin at front.

Incomplete librigenae show a comparatively small eye without socle. Genal angle aspinous. Doublure broad, weakly convex. Anterior extension curves inward and upward; on inner margin, just in front of eye, a single pit projects inward and dorsally upward (PI. 11, fig. 2). This pit would lie immediately below anterior pit at front of axial furrow-compare Failleana calva Chatterton and Ludvigsen (1976, pl. 6, figs. 5,1216). The pit in the doublure, which opposes the anterior pit in Remopleurides (Whittington, 1959, fig. 3c), is analogous.

Hypostome incomplete but comparable to that of 
Bumastus and Cybantyx in the swollen middle body, lateral lobe consisting of large macula, and depressed border. Prosopon of middle body rugose and pitted.

Pygidium strongly convex, rounded triangular to nearly subovate in outline, 85 to 100 per cent as long as wide, almost completely effaced; height 45 to 55 per cent sagittal length. Immature pygidia wider than long. Triangular axis faintly marked by slight change of convexity in some specimens. Articulating facet marked off by a faint oblique ridge; coarse terrace lines running parallel to and overstepping posterior ridge, with steep surface facing backward; raised lines bending perpendicularly backward at margin. Doublure broad, 30 per cent length of pygidium; about 15 shallow discontinuous terrace ridges, equally spaced, running parallel to margin. Surface finely pitted; fine, short raised lines running inward/backward for a short distance abaxially (Pl. 1, fig. 15).

\section{DISCUSSION}

The pygidium of this species is remarkably similar to that of specimens from the Lower Silurian of northeast Greenland, described as "Goldillaenid Genus and species indet. 2" by Lane (1972:347, pl. 62, figs. 10-14). The cranidium differs from that of Lane's material in being much wider, with wider glabella, and in having axial furrows bowed inward and shallowing posteriorly. Lane's material has a terraced anterior border and border furrow similar to that of Cybantyx anaglyptos Lane and Thomas (in Thomas, 1978:18, pl. 5, figs. 1-8). The absence of the border and border furrow in the Road River material is the main feature of the new genus Paracybantyx. Both the Yukon and the Greenland species resemble the type species of Cybantyx in the comparatively narrow, featureless pygidium. Variable features in the cranidium of $P$. asulcatus sp. nov. are the degree of inward curvature of the axial furrows, the anterior and posterior effacement of the axial fur- rows in larger specimens, and the proportions and convexity of the pygidium.

Ptilillaenus Lu (1962), a monotypic genus from the Middle Silurian of China, has an extended axial furrow terminating in an anterior pit and lacks the anterior border, but in that taxon the glabella is narrow.

\section{Indeterminate bumastine}

Pl. 5, figs. 13,14

\section{MATERIAL}

From BB 131 (Lower Silurian), Illtyd Range: 8 cranidia, 1 pygidium.

\section{DESCRIPTION}

Cranidium 60 per cent as long as wide, strongly convex. Glabella effaced, except for lunule at 60 per cent length from front. Posteromedian tubercle at 10 per cent length from back. Anterior pits small, shallow, and rounded, 70 per cent maximum width of cranidium apart, and 20 per cent length of cranidium from front. Palpebral lobe 40 per cent length of cranidium, placed far back, weakly rounded.

Pygidium (not illustrated) 65 per cent as long as wide, strongly convex. Axis 60 per cent anterior width, dying out in a short distance. Anterolateral angle oblique. Surface smooth except for faint terrace ridges on front of cranidium.

\section{DISCUSSION}

The presence of the anterior pits suggests a relationship to species such as Bumastus? phrix Lane and Thomas (in Thomas, 1978:14, pl. 3, figs. 1-22) and B.? xestos Lane and Thomas (in Thomas, 1978:16, pl. 4, figs. 2-5, 7,18 ), both from the British Wenlock. The present species is distinguished by a number of features, particularly the effacement of the axial furrows.

\section{Subfamily Scutelluinae Richter and Richter, 1955}

\section{Genus Kosovopeltis Šnajdr, 1958}

\section{TYPE SPECIES}

Kosovopeltis svobodai Šnajdr, 1958, Kopanina Formation (Upper Silurian), Kosov, Prague district, Czechoslovakia.

Kosovopeltis borealis (Poulsen, 1934)

Pl. 2, figs. 1-12; Pl. 3, figs. 1-10; Pl. 4, figs. 1-13; Pl. 13 , figs. 1,2 ; Text-figs. $4,5 \mathrm{~A}$

Goldius borealis Poulsen, 1934:27, pl. 3, figs. 14,15.
Scutellum borealis-Raasch in Raasch, Norford, and Wilson, 1961:477, figs. 5.6-8,10 (non fig. $5.9=$ Leonaspis semiglabra).

Scutellum borealis-Norford, 1962, pl. 8, fig. 7.

Scutellum borealis-Norford et al., 1970, pl. 8, fig. 9.

\section{HOLOTYPE}

MMH 3267 (cranidium, figured by Poulsen, 1934, pl. 3, fig. 14; in this paper, PI. 13, fig. 1), Cape Schuchert Formation (Lower Silurian), Kap Schuchert, North Greenland. 

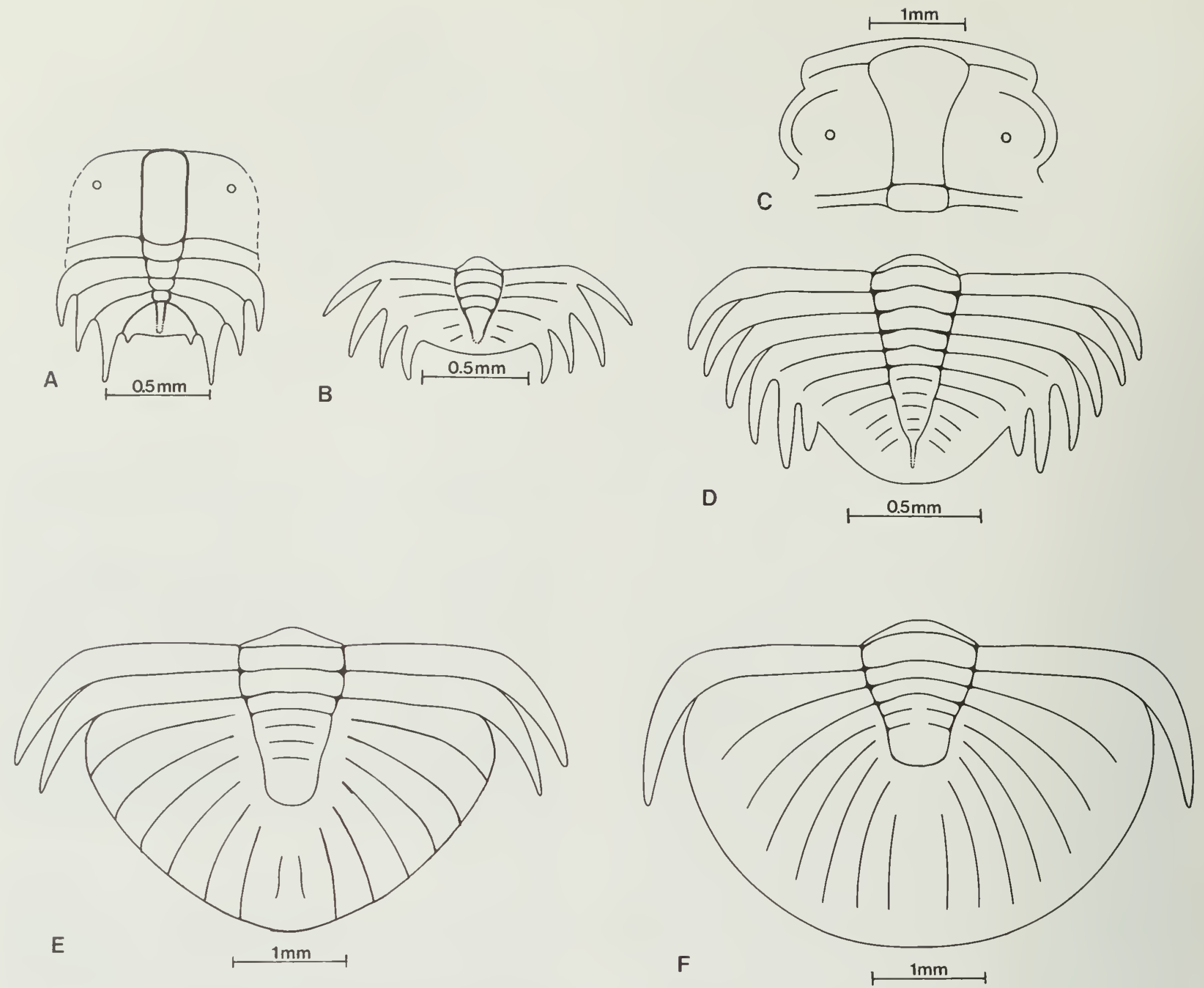

TEXT-F1G. 4. Incomplete ontogeny of Kosovopeltis borealis (Poulsen). A, Protaspis, ROM 42160. B, Smallest transitory pygidium, ROM 42166. C, Meraspid cranidium, ROM 42161. D, Transitory pygidium, ROM 42165. E, Transitory pygidium with two protothoracic segments attached, ROM 42163. $F$, Transitory pygidium with one protothoracic segment attached, ROM 42162.

\section{MATERIAI}

From AA 2-4.5 (Lower Silurian), Prongs Creek: 2 dorsal shields, 78 cranidia, librigenae, rostral plates, 19 hypostomes, 116 pygidia.

\section{DESCRIPTION}

Cephalon about 25 per cent as long as wide. Glabella moderately convex for most of its length, strongly convex and downturned at front, narrowing strongly backward to 30 to 40 per cent anterior width; anterolateral angles strongly rounded. Width of occipital ring greater than width across posterior glabellar ring. Occipital ring bowed backward, summit at posterior margin; minute occipital tubercle centrally situated. Occipital furrow deep and broad mesially, expanding laterally into large, smooth muscle impressions. L1 not swollen, defined only by short, oblique S1; a faint transverse depression marks off preoccipital ring on internal surface only. Muscle scar G1 slightly depressed, 15 per cent length of glabella, placed at about own length anterior to occipital furrow, 30 per cent width of glabella; G2 and G3 indicated by faint, short, smooth lateral depressions at 50 per cent and 25 per cent length of glabella from front, respectively. Anterior border of cranidium extending only a short distance laterally in front of glabella and fixigena. Axial furrow deepening steadily backward, bowed inward. Fixigena broad, convex. Genal muscle area extending alongside Ll and 


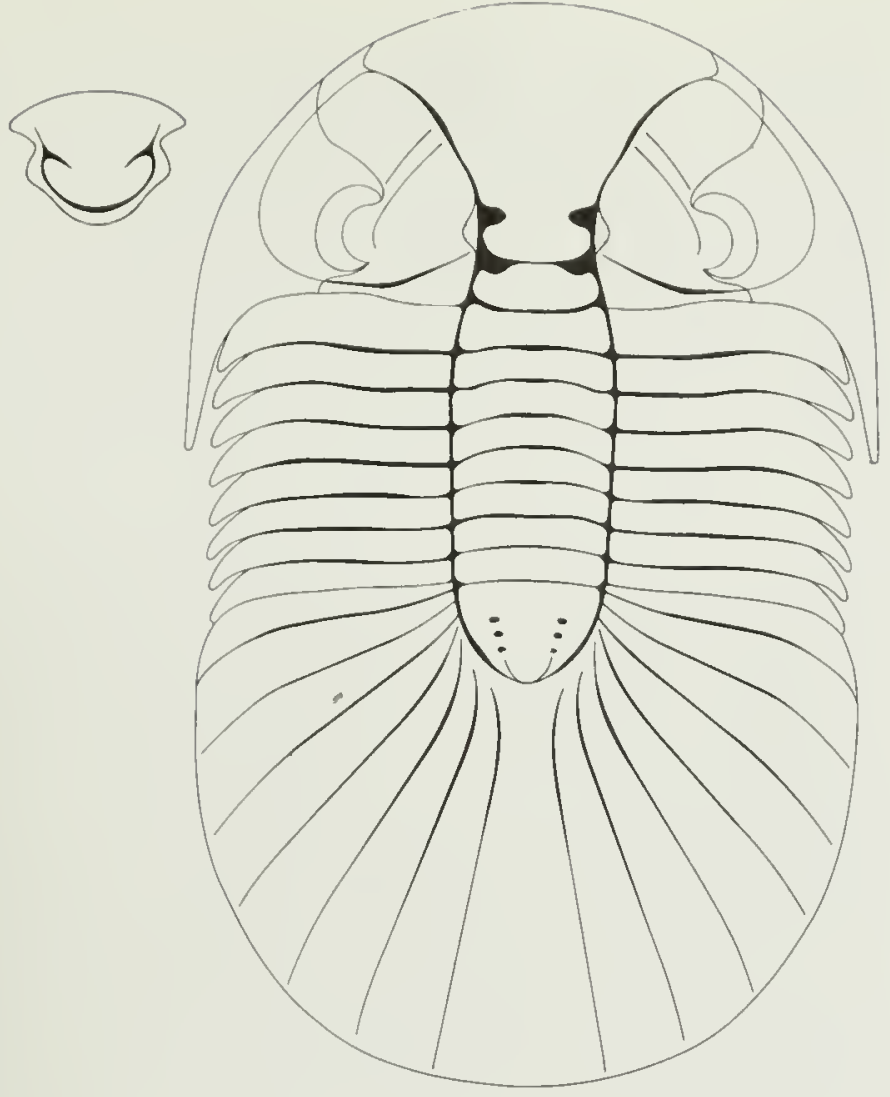

A

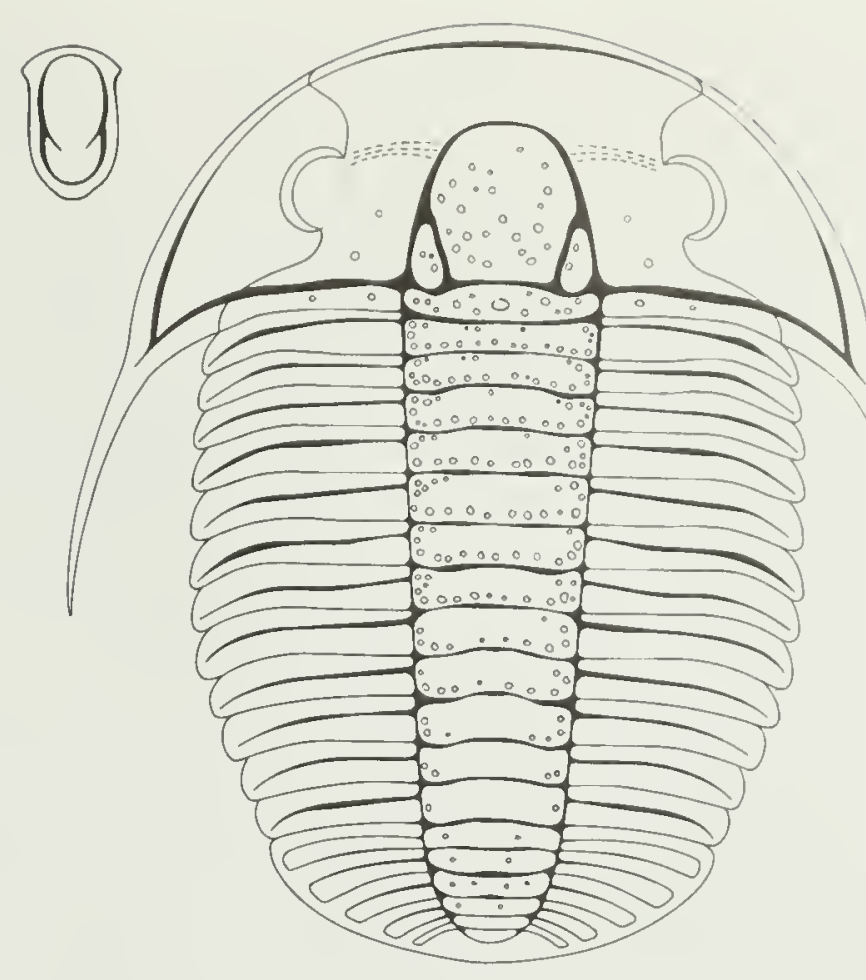

B
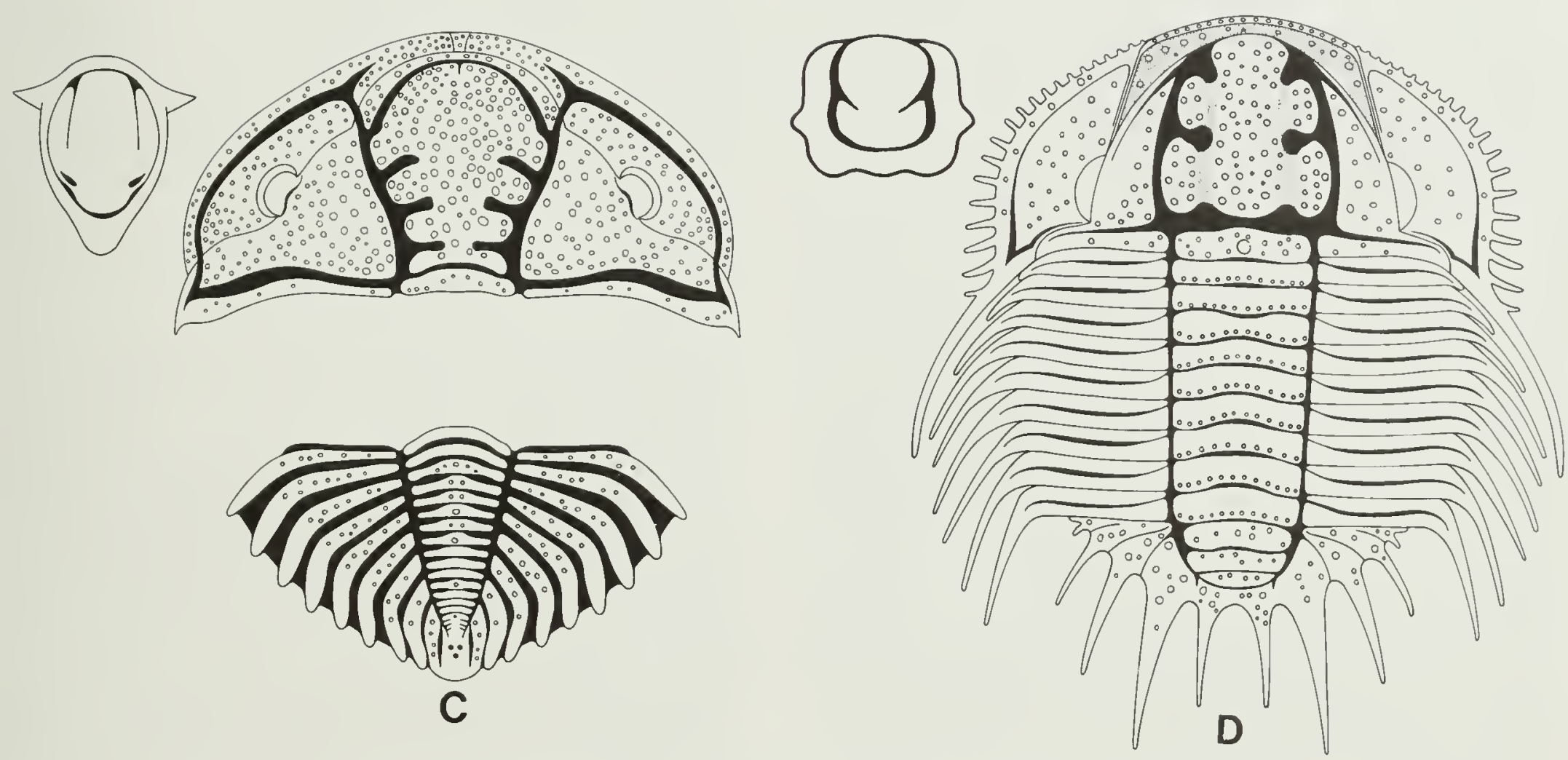

TEXT-FIG. 5. Reconstructions of the four trilobite species from AA 2-4.5, Prongs Creek. A, Kosovopeltis borealis (Poulsen). B, Otarion (Songkania) socialis (Poulsen). C, Cromus princeps (Poulsen). D, Leonaspis semiglabra (Poulsen). 
G1, smooth, slightly depressed. Posterior border much wider (exsag.) than occipital ring adaxially, narrowing strongly to midwidth of fixigena. Posterior border furrow shallow and strongly oblique adaxially. Palpebral lobe at summit of fixigena, opposite L1, 25 per cent length of glabella, horizontal, standing higher than glabella. Eye ridge running obliquely backward and outward from opposite G3, dying out toward back of palpebral lobe. Anterior branch of facial suture running forward and outward, curving forward strongly at anterior margin. Posterior branch curving obliquely outward, cutting posterior margin slightly beyond extent of palpebral lobe.

Librigena falcate, sloping steeply outward; genal spine narrowing slowly backward, extending to third thoracic segment. Eye strongly convex; fully developed lenses hexagonal in outline, $0.02 \mathrm{~mm}$ in diameter $(\mathrm{Pl}$. 4 , figs. 8,9 ). Socle absent. Subocular furrow broad. Field divided by a depression widening and curving inward toward back; outer area narrower and more strongly swollen, widening backward. Lateral border sloping inward to a broad border furrow, furrow also widening backward. Doublure strongly convex, widening and projecting at front, extending to inner area of librigena, and becoming less convex posteriorly.

Rostral plate 25 per cent as long as wide, as wide as glabella anteriorly, extending 30 per cent sagittal length of cranidium, subtrapezoidal in outline, with anterior and posterior margins evenly convex forward and parallel. Convexity moderate; posterolateral angle upturned. Rostral suture submarginal, with connective sutures bowed gently inward.

Hypostome shieid-shaped, 80 per cent as long as wide. Anterior wing narrowly pointed, wide (tr.), without articulating process. Middle body strongly swollen. Middle furrow short but strong, marking off small lateral lobe and macula. Lateral furrow broad. Posterolateral border of uniform width, with inward slope decreasing posteriorly. Posterior margin broadly rounded.

Number of thoracic segments uncertain (dorsal shield [P1. 2, fig. 2] appears to be complete with eight segments, but has some telescoping at the back). Axis 25 per cent width of thorax, narrowing slightly backward, gently convex transversely. Articulating halfrings half sagittal length of rings, bearing faint, transverse raised lines. Pleural lobe horizontally extended as far as fulcrum at 70 per cent width, sloping gently outward abaxially. Pleura narrows abaxially; articulating facet bluntly terminated. Doublure extends to fulcrum.

Pygidium 70 to 85 per cent as long as wide, gently convex. Axis 20 per cent length and width of pygidium, swollen. Articulating half-ring strongly marked off by continuous furrow. Three rings distinguishable on internal surface. Posterior area tripartite, with median lobe swollen, and marked off by longitudinal depressions; three apodemal pits in longitudinal depression marking positions of fourth to sixth ring furrows. Axial furrow uniformly deep throughout. Pleural lobe with seven subequal pairs of ribs, and a median rib flaring posteriorly to three times anterior width. Rib furrows almost straight, progressively wider and shallower toward back, not quite reaching margin. Longitudinal ridge extending for much of postaxial length. Doublure 35 per cent sagittal length of pygidium, weakly convex in ventral view; anterior margin simple, marked on dorsal surface by a low ridge separating convex inner area of pleural lobe from concave outer area (holcos of Helbert et al., 1982:132). Seven broad depressions corresponding to pleural ribs. Longitudinal ridge anteriorly. Fifteen or more semicontinuous terrace ridges running parallel to anterior margin, fainter, wavy, and more closely spaced in outer area.

Wavy, raised lines on surface, except in furrows and muscle areas, distantly spaced, but more closely spaced near margins. Lines run as follows: gently convex forward on glabella; convex inward on fixigena, outward on field of librigena; $\mathrm{V}$ backward on lateral border, with outer limbs longer and more closely spaced; longitudinal on inner side of genal spine; forming a reticulate pattern at base of genal spine; parallel to margin on rostral plate; convex backward on hypostome, including macula; longitudinal on thoracic segments; oblique on first two pygidial ribs and essentially transverse on subsequent ribs.

Protaspides. Protaspis $0.8-0.9 \mathrm{~mm}$ in sagittal length (Pl. 4, figs. 1,2; Text-fig. 4A), subquadrate, slightly wider than long. Cranidium 55 per cent total length; glabella parallel sided, 25 per cent width of cranidium, strongly convex transversely, weakly convex longitudinally. Occipital ring as wide as glabella, convex. Occipital furrow broad, more shallow than axial furrow. Axial furrow deep and broad. Cheek broad and subquadrate, strongly convex and downturned laterally, apparently without border or librigena; a pair of tubercles, 70 per cent maximum width of protaspis apart, toward front. Posterior border 15 per cent sagittal length of cranidium, sharply convex. Posterior border furrow deep and broad. Genal spine not preserved. Pygidium tripartite, very strongly inflated, comprising three segments ending in free points, and a broadly rounded unsegmented area with a fourth pair of small free points laterally. Axis 15 per cent width of pygidium anteriorly; narrowing backward to a point at posterior margin; separating, but lower than, the even more strongly con- 
vex pleural lobes; with three rings strongly marked off by broad ring furrows. Axial furrow strong. First and second pleural ribs almost as strongly developed as occipital segment, becoming less swollen laterally and produced into slender, backwardly directed spines 15 per cent sagittal length of protaspis. Third pleural rib weak. Third spine at least as long as first and second, projecting beyond margin for half its length.

Meraspides. Meraspid cranidium $1.5 \mathrm{~mm}$ in sagittal length (PI. 4, figs. 3,4; Text-fig. 4C), Raymondaspis-like in its subparallel-sided glabella. Glabella 80 per cent as wide as long, with basal width 60 per cent anterior width, strongly convex anteriorly. Axial furrow deep. Anterior border indistinct mesially, developing abaxially; anterior margin flexed upward mesially. Fixigena strongly convex, twice width of glabella at back; eye ridge near front almost transverse. Posterior border depressed, transverse. Posterior border furrow widens abaxially, shallow. Transverse raised lines on glabella; fixigena faintly granular.

Smallest transitory pygidium $0.4 \mathrm{~mm}$ in sagittal length (Pl. 4, figs. 12,13; Text-fig. 4B), incorporating four segments with free points. Articulating half-ring as long as first ring, strongly convex. First free point directed outwardly, second obliquely, third and fourth posteriorly, hindmost longest and projecting well beyond posterior margin. Convexity of pleural lobe of future pygidium increasing rapidly backward, rising above axial area. Surface finely granular.

Transitory pygidium $0.8 \mathrm{~mm}$ in sagittal length ( $\mathrm{Pl} .4$, figs. 10,11; Text-fig. 4D), incorporating six segments with free points. Triangular in outline, 50 per cent as long as wide. Segments decreasing in definition backward, and free points becoming less oblique. Future pygidium strongly convex; axis shorter, more elevated above convex pleural lobe. Surface granular.

Transitory pygidium $2.5 \mathrm{~mm}$ in sagittal length ( $\mathrm{Pl} .4$, figs. 6,7; Text-fig. 4E), incorporating two protothoracic segments with free points and pygidium with seven pleural ribs. Triangular in outline, 55 per cent as long as wide. Axis 20 per cent anterior width, 50 per cent length. Free points becoming successively shorter. Pygidium convex toward back, axis not depressed. Surface smooth.

Transitory pygidium $2.8 \mathrm{~mm}$ in sagittal length (Pl. 4, fig. 5; Text-fig. 4F), incorporating one protothoracic segment with free points. Future pygidium with four axial rings, large and swollen terminus, and seven pleural ribs; broadly rounded and more adult in outline, 60 per cent as long as wide. Pygidium strongly convex, particularly at back. Axis 20 per cent width and 35 per cent length. First two pygidial ribs much wider (exsag.) than subsequent pleurae. Surface smooth.

\section{DISCUSSION}

K. borealis (Poulsen, 1934:27, pl. 3, figs. 14,15) from the Cape Schuchert Formation, North Greenland, was based on four cranidia. Cranidia from the Road River Formation are identical in gross morphology. Minor features supporting specific identity are the minute occipital tubercle and heavy occipital prosopon. The Road River specimens are distinguished from the Kap Schuchert material by the following differences: (1) the prosopon of raised lines is more dense; (2) granulation of the exoskeleton is absent; (3) the eye ridge is broader (exsag.).

The species complies with Šnajdr's diagnosis of Kosovopeltis $(1958: 177 ; 1960: 65)$. It differs from the type species, K. svobodai Šnajdr, and from K. partschi, both from the Kopanina Formation of Czechoslovakia, in that the glabella expands evenly and not abruptly near the front, and that the pygidium is more broadly rounded.

Two scutelluine ontogenies have been described from well-preserved material of the Taemas Formation (Lower Devonian) of New South Wales: Dentaloscutellum hudsoni Chatterton (1971:12, pl. 1, figs. 1-22; pl. 2, figs. 1-14; pl. 3, figs. 1-12; pl. 24, fig. 15) and Scutellum calvum Chatterton (1971:22, pl. 3, figs. 21,22; pl. 4, figs. 1-24; pl. 5, figs. 1-24). The Road River Formation protaspides described above bear a general resemblance to the late protaspides of both species from the Taemas Formation, differing in having a narrow and parallel-sided glabella, broad fixigena, and longer spines. The meraspid cranidium from the Road River Formation differs in having broader fixigena and large eyes that are forwardly placed, and in lacking an occipital spine. There is a close resemblance between the smallest transitory pygidia of $K$. borealis and $S$. calvum (Chatterton, 1971, text-fig. 6D); larger transitory pygidia of $K$. borealis differ from those of $S$. calvum in having protothoracic spines of equal length (cf. alternating lengths). The adult of $K$. borealis does not resemble the adult of either Taemas Formation species.

Šnajdr (1960, pl. 3, fig. 6) has illustrated a meraspid cranidium of the type species bearing an occipital spine; this spine was lost in the holaspis. It is unlikely that such a spine was present in $K$. borealis.

Feist (1970) has described protaspides and meraspides of Breviscutellum (Meridioscutellum) sp. from the Emsian and Eifelian of the Montagne Noire, France. The smallest protaspis, $1.96 \mathrm{~mm}$ in sagittal length, has 8 protothoracic segments developed; the largest has 10 , the number in the adult. These protaspides contrast sharply with those from the Road River Formation 
described above in most features; our largest protaspides are $0.9 \mathrm{~mm}$ in length and have only 4 segments, indicated by free points. There is some similarity in the meraspides in the development of the adult pygidial characters.

Kosovopeltis? spp.

Pl. 9, figs. 8-11

MATERIAL

From BB 131 (Lower Silurian), llltyd Range: 1 cranidium, 3 pygidia.

\section{DISCUSSION}

The fragmentary cranidium differs from $K$. borealis in having a straighter axial furrow, longer occipital ring, weaker occipital furrow, narrower fixigena, and small palpebral lobe posteriorly placed. The three pygidia belong to more than one species. All differ from $K$. borealis in having a wider axis, more strongly curved posterior rib furrows, and an evenly convex surface; one specimen shows the doublure, which is longer than in $K$. borealis, with terrace ridges more widely spaced and more strongly scalloped. The three pygidia differ from each other in the construction of the axis and the median rib, amongst other features, but all are probably attributable to Kosovopeltis.

\section{Indeterminate scutelluine}

Pl. 11, figs. 6,7

\section{MATERIAL}

From AA 95 (Upper Silurian), Prongs Creek: 1 cranidium.

\section{DISCUSSION}

This cranidium differs from Paracybantyx asulcatus sp. nov. in being less convex and in having an anterior border, a faint occipital furrow, a smaller genal muscle area and palpebral lobe, broader fixigena, a conspicuous eye line, and coarsely pitted prosopon. The cranidium is somewhat similar to that of Planiscutellum kitharos Lane and Thomas (in Thomas, 1978:27, pl. 6, figs. 1-8) from the British Wenlock, but it has a much wider axis and a faint occipital furrow.

\section{Family Illaenidae Hawle and Corda, 1847 \\ Subfamily Illaeninae Hawle and Corda, 1847}

\section{Genus Stenopareia Holm, 1886}

TYPE SPECIES

Illaenus linnarssoni Holm, 1882, Boda Limestone (Ashgill), Dalarna, Sweden.

Stenopareia illtyd sp. nov.

Pl. 5, figs. 1-11

\section{DERIVATION OF NAME}

Specific name derived from the Illtyd Range, Yukon Territory.

\section{HOLOTYPE}

ROM 42168 (cranidium, PI. 5, figs. 3,4), locality BB 131 (Lower Silurian), unnamed carbonates, Illtyd Range, Yukon Territory, Canada.

MATERIAL

From BB 131 (Lower Silurian), 1lltyd Range: 9 cranidia, 6 pygidia.

\section{DIAGNOSIS}

Cranidium with strong convexity; palpebral lobes 10 per cent length of cranidium, at own length from posterior margin. Axial furrows convergent. Dendritic muscle impressions strongly developed on glabella and fixigena. Axis of pygidium subtriangular, long, and wide.

\section{DESCRIPTION}

Length (in normal view) 65 to 80 per cent width, convexity strong. Glabella 55 per cent basal width, narrowing forward, but widening slightly at forefont; independent convexity slight. On internal moulds of glabella, shallow radiating ridges and furrows arranged in dendritic pattern alongside smooth median area; foremost ridge large, extending beyond glabella, and continuous with ridges radiating in a quarter segment from posterior inner extremity of fixigena. Axial furrow broad, directed inward for most of length, widening into shallow depressed lunule, and curving outward at front. Fixigena sloping steeply outward with weak convexity. Palpebral lobe 10 per cent length of cranidium, situated at own length from posterior margin, level, and continuous with fixigena. Anterior branch of facial suture running almost straight forward from eye; posterior branch running outward and backward. Internal surface smooth except for muscle impressions. 
External surface sparsely pitted. Faint, transverse raised lines on front of cranidium.

Pygidium 50 to 60 per cent as long as wide, convexity strong posteriorly. Axis subtriangular, 35 per cent anterior width, undefined at back except by slight convexity. Axial furrow broad and shallow anteriorly, becoming steadily shallower and dying out anterior to midlength. Pleural lobe sloping steeply outward, anterolateral angle narrowly rounded, facet steep. Surface covered with transverse anastomosing wavy lines on well-preserved specimens.

\section{DISCUSSION}

S. illtyd sp. nov. closely resembles $S$.? julli Norford (1981:7, pl. 6; pl. 10, figs. 8-10) from the Attawapiskat Formation of northern Ontario, but differs in having much stronger cranidial axial furrows and a less triangular pygidium. In both species, the muscle scars, or caecal markings, on glabellae and fixigenae are comparable. Both species also resemble Stenopareia sp. of Lane (1972:348, pl. 61, figs. 13-15) from the Drommebjerg Limestone (Lower Silurian), northeastern Greenland, a species with comparable muscle scars that are preserved on the external surface of the glabella only.
Indeterminate illaenid

Pl. 5, fig. 12

\section{MATERIAL}

From BB 131 (Lower Silurian), Illtyd Range: 1 cephalon.

\section{DESCRIPTION}

Cephalon 50 per cent as long as wide, strongly convex. Glabella as long as wide, parallel sided. Palpebral lobe 35 per cent length of cephalon, 50 per cent own length from posterior margin. Librigena narrow, gently convex. Eye separated from cheek by broad depression. Genal angle broadly rounded. Surface of cranidium with extremely faint raised lines convergent backward on glabella; minute occipital tubercle posteriorly placed.

\section{DISCUSSION}

The cephalon differs from $S$. illtyd in having a parallelsided glabella, shallower axial furrows, and comparatively large eyes sited far back. It is unlikely that this cephalon can be included in Stenopareia, and its generic affinities are not clear.

\section{Family Proetidae Salter, 1864 \\ ?Subfamily Crassiproetinae Osmólska, 1970}

\section{Genus Hedstroemia Přibyl and Vaněk, 1978}

\section{TYPE SPECIES}

Proetus delicatus Hedström (1923:4, pl. 1, figs. 1-15), Halla Beds, unit b (upper, probably uppermost, Wenlock), Hörsne Canal, Gotland, Sweden.

\section{Hedstroemia kutchini sp. nov.}

Pl. 6, figs. 1-14

\section{DERIVATION OF NAME}

Species named after the Kutchin tribe who formerly inhabited extensive areas of the northern Yukon Territory.

\section{HOLOTYPE}

ROM 45347 (cranidium, Pl. 6, figs. 3,4), locality AA 95 (Upper Silurian), Road River Formation, Prongs Creek, Yukon Territory, Canada.

\section{DIAGNOSIS}

Cephalon with intramarginal ridge between field and border. Genal spine absent. Pygidium elongate with nine rings and eight pairs of pleurae. Prosopon finely granular.

\section{MATERIAL}

From AA 95 (Upper Silurian), Prongs Creek: 9 cranidia, 14 librigenae, 2 hypostomes, 40 pygidia.

\section{DESCRIPTION}

Glabella 90 per cent sagittal length of cranidium, 80 to 90 per cent as wide as long, moderately convex, strongly defined, olive shaped or tongue shaped in outline. Occipital ring narrowing rapidly abaxially, with small occipital tubercle placed slightly posterior to midlength. Occipital furrow and axial furrow moderately deep and narrow. Occipital lobe large, convex, strongly demarcated, extending sideways well beyond main part of ring. L1 faintly defined, with slight independent convexity, almost 30 per cent maximum glabellar width. S1 convex forward, directed inward and backward, widening near midlength, fading at back; S1 bifurcates adaxially, with anterior branch short, shallow, and transverse. S2 shallow, 25 per cent width of glabella, directed slightly backward, situated at 35 per cent length of glabella from front. S3 faint, parallel to S2, situated at 25 per cent length of glabella from front. 
Anterior border of uniform width (sag., exsag.), upturned, convex, wider (tr.) than glabella. Anterior border furrow deep and broad. Between front of fixigena and anterior border furrow, a uniformly narrow and slightly oblique intramarginal ridge, continuous or discontinuous mesially, marked off from preocular area of fixigena by a clear-cut furrow and by independent convexity; prosopon agreeing with the anterior border and differing from the preocular fixigena in lacking granulation; this ridge continuing onto the librigena. Preocular area of fixigena moderately swollen. Palpebral lobe 25 per cent length of cranidium, horizortal, with midlength just posterior to front of $S 1$ and anterior extremity just posterior to $\mathrm{S} 2$; palpebral furrow faint, shallow, running parallel to margin. Postocular fixigena unknown. Anterior branch of facial suture commencing close to axial furrow, curving forward and outward at first, and then running longitudinally. Glabella, preocular fixigena, and palpebral lobe, except in furrows, closely, uniformly, and finely granular; anterior border smooth except for raised lines running parallel to margin.

Eye strongly convex, sloping outward, with subocular furrow deep and broad. Socle swollen, narrowing backward, marked off by a strong furrow. Field gently convex; intramarginal ridge at front of fixigena continuing abaxially on field of librigena as a lateral ridge, widening somewhat backward and dying out before reaching posterior border furrow. Lateral border furrow slightly stronger than furrow marking off the lateral ridge and also dying out before posterior border furrow. Lateral and posterior borders strongly convex, confluent. Genal angle broadly rounded. Field coarsely and shallowly pitted, matching prosopon of fixigena. Surface of field roughened, with raised lines parallel to margin on lateral border.

Hypostome as wide as long. Middle body large, well defined, convex, extending to anterior margin. Middle furrow oblique, short and shallow, commencing at 65 per cent length of middle body from front. Lateral lobe with oval macula abaxially, merging with middle body adaxially. Lateral furrow deepens and widens steadily backward, continuous with posterior furrow, which is broad and strongly convex backward. Lateral borders raised, subparallel, widening steadily backward, and slightly outturned just posterior to level of middle furrows. Posterior border depressed, strongly convex backward in outline. Anterolateral wing subquadrate, downturned; articulating process absent. Middle body faintly and coarsely pitted, bearing raised lines mesially, divergent backward for most of length, transverse anteriorly. Raised lines on lateral border running parallel to margin.

Pygidium 60 to 75 per cent as long as wide, strongly convex in both directions, high in profile, with height 60 to 70 per cent sagittal length. Axis convex, 45 to 50 per cent maximum width and 80 to 90 per cent length of pygidium, narrowing strongly backward to rounded tip, composed of nine rings and a short terminus. Ring furrows shallow, gently sinuous, bowed backward mesially; furrows toward front strong, becoming successively fainter toward back, particularly abaxially. Paired muscle insertion scars distinguishable on some specimens. Axial furrow clear cut. Pleural lobe convex. Seven welldefined pleurae; eighth faint. First pleural furrow broad, narrowing abaxially, but reaching lateral margin; first interpleural furrow well developed, dying out at lateral depression. Subsequent pleural and interpleural furrows successively fainter, dying out at lateral depression. Lateral border uniformly narrow, sloping outward with moderate convexity. Border depression strong but ending at first pleura. Articulating facet smooth. Surface densely but somewhat variably granular.

\section{DISCUSSION}

H. kutchini sp. nov. closely resembles the type species, H. delicata (Hedström, 1923:4, pl. 1, figs. 1-15), Halla Beds, Hörsne Canal, Gotland, Sweden; an allied form has been described under open nomenclature by Helbert et al. (1982:138) from the Lower Silurian of the Oslo Region, Norway. Bob Owens (pers. comm., 1987) confirms that $H$. delicata has a flat intramarginal area between the border furrow and the change of slope of the field of the fixigena and librigena, comparable with the intramarginal ridge of $H$. kutchini; Owens also confirms that $H$. kutchini differs from $H$. delicata in having stronger lateral glabellar furrows and a less-angular frontal glabellar lobe, in lacking a genal spine, in having a hypostome with more pronounced posterior wings and a broader posterior border furrow, and in having a pygidium composed of fewer segments with a narrower border. Shared features are the greatly swollen occipital lobes; similar hypostomes, particularly as regards the prosopon; and the faint pygidial ring furrows with paired muscle scars abaxially. H. kutchini bears a resemblance to Coniproetus (Coniproetus) affinis affinis (Bouček, 1933; see Šnajdr, 1980:73, pl. 9, figs. 3-11), from the basal Lochov Formation (Lochovian), Reporyje, Prague, Czechoslovakia, particularly as regards glabellar features, the librigena, the hypostome, and the distinctably faint ring furrows of the pygidium. H. kutchini differs in having stronger lateral glabellar furrows, a narrower (sag., exsag.) anterior border, more posteriorly placed palpebral lobes, an intramarginal ridge, and a more elongate pygidium with eight pleural ribs. The pygidium of $H$. kutchini also differs in proportions, and in having stronger pleural segmentation, and a much 
narrower and more strongly defined border; these pygidial features readily distinguish Hedstroemia from Coniproetus.

The hypostome bears a resemblance to that of $\mathrm{Co}$ niproetus $(C$.) whittakerensis (Chatterton and Perry, 1977, pl. 1, figs. 7-10) from the Early Devonian of northwestern Canada, but differs in having a morerounded posterior border and raised lines on the front of the middle body that run transversely, not longitudinally. There is little resemblance between the cranidia of the two species- H. kutchini has a much broader (tr.) glabella, and narrower (sag., exsag.) anterior border.

\section{Hedstroemia sourdoughi sp. nov.}

Pl. 6, figs. 16-24

\section{DERIVATION OF NAME}

Species named after those prospectors (Sourdoughs) who chose the all-Canadian route to the goldfieldsdown the Mackenzie River, up the Peel River, up the Wind River, past Prongs Creek, and then overland to the Klondike.

\section{HOLOTYPE}

ROM 45332 (cranidium, Pl. 6, figs. 22,23), locality AA 95 (Upper Silurian), Road River Formation, Prongs Creek, Yukon Territory, Canada.

\section{DIAGNOSIS}

Glabella strongly convex, frontal lobe rounded. Pygidium short, composed of eight rings and six pairs of pleurae; axis comparatively narrow; ring furrows well defined; border broad. Prosopon coarsely granular.

\section{MATERIAL}

From AA 95 (Upper Silurian), Prongs Creek: 8 cranidia, 2 librigenae, 25 pygidia.

\section{DESCRIPTION}

Cranidium closely similar to $H$. kutchini sp. nov. in many respects, differing in the following features. Glabella more convex. Occipital tubercle small or absent. Occipital furrow deeper, S1 stronger, S2 and S3 fainter. Intramarginal ridge present but discontinuous mesially. Pygidium shorter, 50 to 60 per cent as long as wide. Axis of eight rings and a short terminus; ring furrows much deeper and less sinuous. Paired muscle insertion scars distinct on surface of most specimens. Pleural lobe more convex, with six pleurae and deeper and broader border depression; border broader, of uniform width. Prosopon of cranidium and pygidium coarsely and densely (cf. finely) granular.

\section{DISCUSSION}

$H$. sourdoughi sp. nov. closely resembles $H$. kutchini sp. nov. in cranidial features, particularly in the presence of the intramarginal ridge. It also stands close to Coniproetus bohemicus Hawle and Corda (see Šnajdr, 1980:58, pl. 6, figs. 1-14; pl. 61, fig. 4; pl. 63, fig. 6) from the Koneprusy Limestone, Czechoslovakia, particularly as regards glabellar outline, the definition of the lateral glabellar furrows, strong pygidial ring furrows, broad pygidial border, and coarse prosopon. H. sourdoughi sp. nov. differs from $H$. kutchini in having an intramarginal ridge and stronger pygidial furrows. The cranidium of $H$. sourdoughi differs from that of $C$. bohemicus in having a narrower (sag.) anterior border, smaller palpebral lobes, and an intramarginal ridge (discontinuous mesially).

Subfamily Warburgellinae Owens, 1973

\section{Genus Prantlia Přibyl, 1946}

\section{TYPE SPECIES}

Proetus longulus Hawle and Corda, 1847, Kopanina Formation, Upper Silurian, Prague district, Czechoslovakia.

\section{Prantlia vagrans sp. nov.}

Pl. 7, figs. 1-15

\section{DERIVATION OF NAME}

Specific name derived from Latin vagrans (wandering), in allusion to the wide distribution of this genus.

\section{HOLOTYPE}

ROM 45363 (pygidium, Pl. 7, figs. 6,7), locality AA 95 (Upper Silurian), Road River Formation, Prongs Creek, Yukon Territory, Canada.

\section{DIAGNOSIS}

A warburgelline with short frontal area, glabella 80 per cent sagittal length of cranidium, supplementary lobe adaxial to L1, strong S1, and posterior bands of second and third pygidial pleurae crossing border.

\section{MATERIAL}

From AA 95 (Upper Silurian), Prongs Creek: 16 cranidia, 22 librigenae, 48 pygidia. 


\section{DESCRIPTION}

Glabella 80 per cent sagittal length of cranidium, 75 per cent as wide as long, moderately convex, strongly defined, anterior outline narrowly rounded. Occipital ring narrowing rapidly abaxially; occipital tubercle small, centrally placed. Occipital lobe large, convex, strongly demarcated, extending sideways well beyond main part of ring. Occipital furrow deep and moderately broad. L1 strongly defined, subtriangular, with strong independent convexity, 30 per cent maximum glabellar width. S1 deepening rapidly, running obliquely inward and backward, shallowing and widening at back. In several specimens, S1 forming a short, transverse branch of varying strength toward front of L1, defining a small supplementary lobe marked by a short furrow posteriorly and by slight independent convexity. S2 faintly impressed, 25 per cent width of glabella, almost transverse, situated at 30 per cent length of glabella from front. S3 as S2 but slightly convergent forward, situated at 25 per cent length of glabella from front. Axial furrow straight, extremely deep and broad. Preglabellar area marked off from preocular fixigenae by a shallow, almost transverse depression. Anterior border one-third length of preglabellar area, hardly narrowing abaxially, convex. Anterior border furrow shallow but distinct. Frontal area weakly convex and marked off from the more strongly convex preocular fixigena by a faint but broad depression convex forward. Palpebral lobe small, 25 per cent length of cranidium, horizontal, with anterior extremity opposite S2; palpebral furrow faint, shallow. Postocular fixigena unknown. Anterior branch of facial suture commencing close to axial furrow, curving forward and outward, and bending inward at anterior border furrow. Glabella closely granular, except in furrows, with granulation becoming finer toward front; anterior border finely granular, with delicate raised lines running parallel to that border; preglabellar area and preocular fixigena coarsely and shallowly pitted, with raised lines and a few scattered granules; palpebral lobe finely granular.

Eye strongly convex and sloping outward, separated by shallow furrow from low, narrow socle set on a ridge narrowing backward. Field convex. Lateral border furrow deep and broad, continuing into genal spine; lateral border ill defined, half minimum width of field, extending alongside genal spine. Posterior border strongly developed and extended alongside broad-based genal spine reaching backward for about 35 per cent estimated sagittal length of cephalon. Field coarsely and shallowly pitted, matching prosopon of fixigena. Closely spaced raised lines run forward and inward on outer area of lateral border; posterior to midlength, raised lines become chevron shaped, with shorter, posteriorly directed limb on inner area of border; posterior border with similar prosopon alongside spine.

Pygidium 60 to 70 per cent as long as wide, moderately convex in both directions. Axis 30 to 35 per cent maximum width of pygidium, 85 to 90 per cent length of pygidium, narrowing slowly backward to rounded tip, composed of twelve rings and a short terminus. Ring furrows gently sinuous, strong anteriorly, becoming successively fainter, particularly abaxially. Axial furrow narrow. Pleural lobe convex; border depression strong but dying out at first pleura. Seven well-defined pleurae; eighth faint. First pleural furrow broad, narrowing abaxially, but reaching lateral margin; first interpleural furrow uniformly narrow and shallow, just reaching lateral margin. Subsequent pleural and interpleural furrows deep and broad adaxially, successively fainter, and dying out at lateral border furrow, except second and third posterior bands and interpleural furrows extending halfway across lateral border. Lateral border narrowing slightly forward, sloping outward with moderate convexity. Articulating facet smooth. Doublure as wide as lateral border. Ten almost-continuous terrace lines running subparallel to margin. Surface granular; raised lines directed inward and forward on anterior part of border. One pygidium (Pl. 7, fig. 13) showing a deformity in having a slight embayment in the posterior outline.

A meraspid cranidium, $2.2 \mathrm{~mm}$ in sagittal length ( $\mathrm{Pl}$. 7, fig. 10), differing little from adult cranidium except in its narrower glabella and smaller occipital lobe.

\section{DISCUSSION}

$P$. vagrans $\mathrm{sp}$. nov. bears a close resemblance to the type species, Prantlia longula Šnajdr (1980:180, pl. 34, figs. 1-8), in many respects, such as the following: glabellar outline, development of the lateral glabellar furrows, large occipital lobes, segmentation and narrow axis of pygidium, and the manner in which the lateral border furrow dies out at the first pleura. P. vagrans differs from the type species in the following features: (1) the glabella is 80 per cent the length of the cranidium (cf. 65 to 70 per cent), the preglabellar field being much shorter; (2) S2 is transverse (cf. slightly convergent backward); (3) the frontal lobe is narrower; (4) the pygidium is relatively longer, being comprised of 12 (cf. 10) rings, and has a narrower and more convex border; (5) the postaxial ridge on the pygidium is absent.

The librigena of $P$. vagrans resembles that of the warburgelline Tetinia in morphology and also particularly in the oblique raised lines on the outer area of the lateral border. Prantlia differs from Warburgella in the 
absence of the tropidium.

Other species of Prantlia-P. longifrons (Lindström, 1885), from the Hemse Beds (Upper Silurian), Gotland, Sweden; P. grindrodi Owens (1973; Thomas, 1978), Wenlock Shale, Malvern, United Kingdom; and P. canberrensis Chatterton and Campbell (1980), Lower Silurian, Canberra, Australia-differ considerably from the type species and from $P$. vagrans, as the comparison in Table 2 demonstrates; the subgenus Malvernocare has been proposed for $P$. grindrodi by Prribyl and Vaněk (1978). Chatterton and Campbell (1980:85) considered Latiproetus Lu (1962:162) to be synonymous with Prantlia, drawing attention to the similarity between the type species L. latilimbatus (Grabau) and P. grindrodi. Kobayashi (1985:419) considered Latiproetuss to be valid, and he referred Prantlia biloba Kobayashi and Hamada (1974:118, pl. 12, figs. 8,9a,b), Okanari, Shikoku Island, Japan, to Latiproetus; he regarded Chuanqianoproetus Wu, 1977; Xiushuiproetus Q. Zhang in Qiu et al., 1983; and possibly Malvernocare as subgenera of the genus. In our opinion, more detailed knowledge about the morphology of the taxa concerned is required before a satisfactory revision can be proposed.

TABle 2. Summary of diagnostic characters of the species of Prantlia. glab., glabellar; \%, as percentage of; cranid., cranidial; no., number.

\begin{tabular}{lccccc}
\hline & longula & vagrans & $\begin{array}{c}\text { Species } \\
\text { canberrensis }\end{array}$ & longifrons & grindrodi \\
\hline $\begin{array}{l}\text { CEPHALON } \\
\text { glab. shape }\end{array}$ & triangular & triangular & bell & bell & bell \\
glab. length \% cranid. length & 68 & 82 & 66 & 61 & 62 \\
genal spines & yes & yes & yes & $?$ & yes \\
THORAX & & & & & \\
no. of segments & 9 & $?$ & 8 & 9 & 10 \\
$\begin{array}{l}\text { PYGIDIUM } \\
\text { no. of rings } \\
\text { no. of pleurae }\end{array}$ & & & & & \\
\hline
\end{tabular}

\section{Subfamily uncertain}

\section{Indeterminate proetid $A$}

Pl. 6, fig. 15

\section{MATERIAL}

From AA 95 (Upper Silurian), Prongs Creek: 1 hypostome.

\section{DISCUSSION}

One small hypostome (Pl. 6, fig. 15) lacks the posterior embayment of warburgellines, and differs greatly from the hypostome of $H$. kutchini in the following features: it is much more elongate, with different prosopon; the middle body is pinched in and produced anteriorly; paired posterolateral denticles are present. We do not know of a comparable hypostome and leave its systematic position undecided.

\section{Indeterminate proetid $B$}

Pl. 9, figs. 4,5

\section{MATERIAL}

From BB 131 (Lower Silurian), Illtyd Range: 1 cranidium, 1 hypostome, 1 pygidium.

\section{DESCRIPTION}

Fragmentary cranidium with subquadrate glabella as long as wide. Lateral lobes apparently absent. Preglabellar and axial furrows shallow. Occipital ring 10 per cent length of cranidium. Occipital tubercle and lobe absent. Preglabellar area 20 per cent length of cranidium, not downturned; preglabellar field gently convex. Anterior border short. Anterior furrow shallow.

On hypostome, width across posterior wings 85 per cent length. Middle body swollen, strongly defined. 
Middle furrow commencing at 60 per cent length of hypostome from front, inclined backward and inward for 20 per cent width. Lateral lobe composed almost entirely of strongly swollen, smooth macula. Lateral furrow shallow anteriorly, becoming deeper and broader toward back, bending outward opposite macula. Posterior furrow convex backward, broad, and shallow. Lateral border narrow, raised, continuous with posterior border; posterior border broader mesially; lateral denticle absent. Raised lines running backward and outward on middle body, parallel to margin on borders.

\section{DISCUSSION}

The hypostome resembles that of Hedstroemia kutchini sp. nov., particularly in the rounded posterior outline and large maculae, but differs in having an undepressed posterior border and in prosopon. The cranidium and unillustrated pygidium are unlike Hedstroemia and are unidentifiable.

\section{Family Aulacopleuridae Angelin, 1854}

\section{Genus Otarion Zenker, 1833}

\section{TYPE SPECIES}

Otarion diffractum Zenker, 1833, from Upper Silurian rocks near Beroun, Prague district, Czechoslovakia.

\section{DISCUSSION}

In their review of the family Aulacopleuridae, Thomas and Owens (1978) suggested that Otarion (Otarion) be restricted to Late Silurian aulacopleurid species with, among other features, faint eye ridges visible on internal moulds, a subparallel-sided glabella, weakly divergent preocular facial sutures, and 13 to 17 thoracic segments, the sixth segment bearing an axial spine. They proposed that $O$. (Aulacopleura) be restricted to species from the Ordovician to Middle Devonian with strong eye ridges evident on the external surface and with 18 to 22 thoracic segments, none bearing an axial spine. Aulacopleura socialis (Poulsen), from the Early Silurian, bears conspicuous eye ridges, a glabella of parabolic outline, widely divergent facial sutures, and 12 thoracic segments, with an axial spine on the sixth segment in some specimens. These features preclude assignment to either subgenus, but are shared with Songkania Chang from the Early Silurian of southwest China, which we regard as a third subgenus of Otarion.

\section{Subgenus Songkania Chang, 1974}

\section{TYPE SPECIES}

Songkania hanjiadianensis Chang, 1974, Early Silurian, southwest China.

Otarion (Songkania) socialis (Poulsen, 1934)

Pl. 4, fig. 14; PI. 8, figs. 1-12; Pl. 12, figs. 14-16; Pl. 13, figs. 3-6; Text-fig. 5B

Aulacopleura socialis Poulsen, 1934:21, pl. 2, figs. 2427.
Aulacopleura socialis - Raasch in Raasch, Norford, and Wilson, 1961:471, fig. 4.1-9.

\section{HOLOTYPE}

MMH 3251 (cranidium, figured by Poulsen, 1934, pl. 2, fig. 25; in this paper, Pl. 13, figs. 3,4), Cape Schuchert Formation (Lower Silurian), Kap Schuchert, North Greenland.

\section{MATERIAL}

From AA 2-4.5 (Lower Silurian), Prongs Creek: 7 dorsal shields, 270 cranidia, librigenae, 3 hypostomes, 78 pygidia.

\section{DESCRIPTION}

Length of cephalon 40 per cent width opposite occipital ring. Glabella 80 to 90 per cent as wide as long, 55 to 60 per cent length of cranidium (in normal view), subquadrate, gently convex; anterolateral angles broadly rounded. Occipital ring moderately convex, with posterior margin bowed backward. Occipital tubercle centrally placed. Occipital furrow shallower than axial furrow. L1 with slight independent convexity, 30 per cent length of glabella and 20 per cent width of glabella. S1 broad and strong anteriorly, becoming weak posteriorly, running obliquely backward to occipital furrow. S2 short, distinct only on internal surface. Preglabellar and axial furrows continuous, deepening posteriorly. Preglabellar field as long as glabella when measured along surface, curving downward with moderate convexity, confluent with fixigena. Fixigena wide, sloping inward from palpebral lobe. Palpebral lobe horizontally extended, with extremities almost twice width of glabella apart; midlength of palpebral lobe opposite midlength of glabella. Eye ridge strong, slightly oblique, divided by a median furrow. Anterior border moderately wide and convex, with sagittal length greater than exsagittal length. Anterior border furrow uniformly well defined. Anterior branch of facial suture running sinuously forward and outward, cutting anterior margin 
at 65 per cent width across genal angles. Posterior branch running backward and outward, cutting margin at 80 per cent width across genal angles. Doublure extending to border furrow.

Eye 20 per cent sagittal length of cephalon; strong convexity differentiating from narrow socle; socle marked off from librigena by a broad, shallow furrow. Field of librigena considerably wider than preglabellar area, moderately convex, sloping outward; caecae present on some specimens. Lateral border convex, 30 per cent minimum width of field, continuous with anterior and posterior borders; anterior and posterior borders widening rapidly adaxially. Genal spine long and slender, extending to sixth thoracic segment, arising abruptly at genal angle, directed slightly outward and backward, almost straight.

Rostral plate unknown. Hypostome elongate. Middle body large, extending to anterior margin, strongly convex. Lateral lobes large, uniting to form a posterior lobe with independent convexity. Middle furrow oblique, shallow. Anterior wing small. Lateral border narrow, convex, directed longitudinally for much of length, diverging posteriorly, and curving round to unite with rounded posterior border. Lateral denticle absent.

Thorax composed of 12 segments. Axis 30 per cent width of thorax anteriorly, narrowing to 65 per cent anterior width of axis posteriorly, gently convex transversely. Axial furrow well defined. First five rings with swollen lateral nodes. Articulating half-ring more than half length of ring. Pleural lobe horizontally extended adaxially, gently downturned at fulcrum at 60 per cent width. Pleura composed of anterior and more strongly swollen posterior bands, separated by median pleural furrow; extremity of pleura rectangular. Axial spine on sixth ring on at least two individuals (Pl. 8, figs. 6-8), tapering slowly and curving low over axis to twelfth ring; spine certainly absent on other specimens (Pl. 8, fig. 5).
Pygidium 35 to 40 per cent as long as wide. Axis 30 per cent anterior width of pygidium, 85 per cent length of pygidium, moderately convex. Terminus broadly rounded. Five rings clearly marked by continuous ring furrows, successively shorter. Pleural area increases strongly in convexity toward back. Border uniformly narrow, continuous. Four well-defined pleurae and a posterior area; anterior bands confluent with border, widening abaxially. Posterior bands more swollen, narrowing out at border furrow, delimited by pleural and interpleural furrows; pleural and interpleural furrows fuse to form border depression. Doublure narrow.

Surface smooth except as follows: coarse granules on glabella; two pairs of small granules on adaxial area of fixigena, anterior pair closer to axial furrow than posterior pair; a row of granules on occipital and thoracic rings; faint granules on axis of pygidium. External surface of field of librigena closely and shallowly pitted; lateral border of librigena with very faint, closely spaced raised lines running parallel to margin. Internal surface of librigena smooth.

\section{DISCUSSION}

The only differences between the specimens from the Road River Formation and the type material from North Greenland are the stronger granulation and the weaker development of S2 in the Road River Formation material. It is not known whether or not an axial thoracic spine was present in the Greenland material; the material under description is dimorphic in this respect.

The cranidium of $O$. (S.) socialis resembles $O$. (S.) pijiazhaiensis Chang (1974:174, pl. 81, fig. 10) more closely than it does the type species, $O$. (S.) hanjiadianensis Chang (1974:174, pl. 80, figs. 3,4; pl. 81, fig. 9); differences in the Road River Formation material from that of both other species are the broader L1, the longer preglabellar field, and the presence of granulation.

\section{Family Harpidae Hawle and Corda, 1847}

\section{Genus Scotoharpes Lamont, 1948}

\section{TYPE SPECIES}

Scotoharpes domina Lamont, 1948, Whether Law Linn Formation (upper Llandovery), Whether Law Linn, North Esk Inlier, Scotland.

\section{Scotoharpes raaschi Norford, 1973}

Pl. 9, figs. 1-3

Scotoharpes raaschi Norford, 1973:20, pl. 2, figs. 1,3-5.

\section{HOLOTYPE}

GSC 27794 (cephalon, figured by Norford, 1973, pl. 2, figs. 1,3-5), Lower Silurian, GSC locality 53109 (probably the same as BB 131), Illtyd Range, Yukon Territory, Canada.

\section{MATERIAL}

From BB 131 (Lower Silurian), Illtyd Range: 2 cephala.

\section{DESCRIPTION}

Cephalon 65 per cent as long (sag.) as wide. Glabella 
40 to 45 per cent length of cephalon and 20 per cent width of cephalon, moderately swollen, as wide as long. Width of occipital ring equal to width across L1; occipital tubercle strong, anteriorly placed. Occipital furrow shallow, transverse. L1 small, 30 per cent length of glabella, projecting only slightly sideways. S1 shallow, curving inward and dying out anterior to midlength of L1. Preglabellar and axial furrows continuous, shallow. Ala moderately large, 30 per cent width of glabella, sloping outward and depressed abaxially, narrowing and dying out anterior to midlength of glabella. Fixed cheek convex; a low ridge outlining ala anteriorly. Eye tubercle only slightly elevated, 30 per cent width of cephalon from midline, situated opposite forefront of glabella. Eye ridge clearly defined, essentially transverse; ridge of comparable strength running obliquely outward from eye tubercle to cheek roll. Cheek roll extending almost to glabella anteriorly, sloping steeply outward, narrowing and dying out at 60 per cent length from front. Posterior border short, convex, curving strongly backward abaxially. Girder weak. Brim flattened, slightly wider anteriorly than laterally; prolongation 40 per cent sagittal length of cephalon, narrowing slowly backward, slightly inturned posteriorly. Marginal band narrow, smooth. Doublure of occipital ring almost reaches occipital furrow. Glabella, occipital ring, and ala smooth; cheek coarsely pitted, with pits on cheek roll finer than on cheek and arranged in ramifying, radiating rows separated by fine caecae. Caecae continuing 20 per cent distance across brim. Brim finely pitted. Pits on either side of girder larger.

\section{DISCUSSION}

A point of particular resemblance of our material to $S$. raaschi Norford is the ridge running obliquely outward from the eye tubercle. The occipital tubercle described above is present on the external surface only and is not preserved on the holotype cephalon.

Family Cheiruridae Hawle and Corda, 1847

Subfamily Cheirurinae Hawle and Corda, 1847

\section{Genus Cheirurus Beyrich, 1845}

TYPE SPECIES

Cheirurus insignis Beyrich, 1845, Liten Formation (Upper Silurian), Prague district, Czechoslovakia.

Cheirurus sp.

Pl. 5, figs. 15,16

\section{MATERIAL}

From BB 131 (Lower Silurian), llltyd Range: 1 cranidium, 1 fragmentary librigena.

\section{DESCRIPTION}

Anterior part of glabella (all that is known) expanding slightly forward, moderately convex. S2 and S3 curving gently backward, 30 per cent width of glabella. Anterior border short; anterior border furrow shallow mesially, deeper abaxially. Prosopon faintly granular. The unillustrated librigena is of generalized cheirurine type.

\section{DISCUSSION}

This species differs from C. certus Poulsen (1934:28, pl. 3, fig. 16) and C. hyperboreus Poulsen (1934:29, pl. 3, figs. 17,18), both from the Cape Schuchert Formation, North Greenland, in its shorter, less-expanded frontal lobe.

Family Encrinuridae Angelin, 1854

Subfamily Encrinurinae Angelin, 1854

\section{Genus Cromus Barrande, 1852}

\section{TYPE SPECIES}

Trilobites intercostatus Barrande, 1846, Kopanina Formation (Upper Silurian), Prague district, Czechoslovakia.

Cromus princeps (Poulsen, 1934)

Pl. 10, figs. 1-8; Pl. 13, figs. 7-12; Text-fig. 5C

Encrinurus moderatus Poulsen, 1934:31, pl. 3, fig. 20 (non figs. 21,22).

Encrinurus princeps Poulsen, 1934:33, pl. 3, figs. 23-27. Encrinurus princeps-Raasch in Raasch, Norford, and Wilson, 1961, fig. 5.1-5.

Encrinurus cf. E. princeps-Norford, 1962, pl. 8, fig. 14. Encrinurus cf. E. princeps-Norford et al., 1970, pl. 8, fig. 14.

Cromus princeps-Strusz, 1980:10.

Cromus princeps-Šnajdr, 1985:16.

Encrinurus moderatus-Lane, 1988:99, pl. 5, figs. 7,?8. 


\section{IIOLOTYPE}

MMH 3276 (cranidium, figured by Poulsen, 1934, pl. 3, fig. 23; in this paper, Pl. 13, figs. 10,11), Cape Schuchert Formation (Lower Silurian), Kap Schuchert, North Greenland.

\section{MATERIAL}

From AA 2-4.5 (Lower Silurian), Prongs Creek: 1 dorsal shield, 10 cranidia, librigenae, 4 hypostomes, 23 pygidia.

\section{DESCRIPTION}

Cranidium 45 per cent aś long as wide. Glabella 70 to 80 per cent as wide as long, moderately convex in both directions; width across L2 60 to 65 per cent maximum width. Occipital ring wider than width across L1, with transverse posterior margin narrowing slightly abaxially. Occipital furrow broad and shallow mesially, shallower than axial furrow abaxially; rounded apodeme at extremity. L1 consisting of a ridge 35 per cent width of glabella, directed somewhat forward adaxially; L2 shorter than L3, nodular; L3 subquadrate. S1 almost continuous; S2 and S3 broad abaxially, dying out adaxially, 35 per cent width of glabella. Frontal lobe 40 to 45 per cent length of glabella, evenly and strongly rounded in outline. Axial furrow deeper and broader than preglabellar furrow, widening backward; apodemes adaxially at extremities of S1 and S2. Preglabellar furrow deep and wide abaxially, becoming shallower and narrower mesially. Anterior border of cranidium moderately wide abaxially, narrowing and almost dying out mesially. A longitudinal median depression crossing anterior border and preglabellar furrow, and running onto forefront of glabella; this depression stronger in small specimens. Fixigena wide, sloping inward from eye with strong convexity and outward to genal angle with weaker convexity. Palpebral lobe almost 20 per cent length of cranidium and marked off from fixigena by a broad, shallow depression; anterior extremity of palpebral lobe placed opposite, and at twice width across, L3. Posterior border narrower (exsag.) than occipital ring, widening slowly abaxially and rapidly adjacent to genal angle, depressed well below level of fixigena abaxially. Lateral border ill defined. Posterior border furrow deep adaxially, where continuous with lateral furrow. Genal spine thornlike, very short, directed backward and slightly outward. Anterior branch of facial suture curving forward and inward, delimiting anterior border of cranidium. Posterior branch curving outward and backward, cutting lateral margin opposite occipital furrow.

Eye pedunculate; lens surface occupying half height of stalk; stalk marked off by a broad depression from field. Field of librigena gently convex. Preglabellar lobe 25 per cent length of cranidium, weakly convex. Lateral border strongly convex, less than half minimum width of field, continuous with anterior border, curving inward and widening at back. Lateral border furrow uniformly deep and broad. Anterior border furrow deep and broad at axial furrow, narrowing and dying out by midwidth of preglabellar lobe.

Rostral plate unknown, but conformation between librigenae indicating a narrow plate widening forward, as shown in reconstruction.

Hypostome 75 per cent as wide as long. Middle body strongly swollen, longitudinally ovate, with a lessinflated terminal area. Rhynchos broad, with independent convexity anteriorly but projecting slightly, length equalling half that of middle body. Lateral lobe comprising a small, smooth macula. Lateral furrow demarcating middle body strongly. Lateral border narrow, flattened, merging with posterior tongue; tongue 25 per cent length of hypostome and with rounded tip. Middle body closely and shallowly pitted, more coarsely so anteriorly.

Pygidium triangular in outline, 55 to 60 per cent as long as wide. Axis 25 per cent anterior width and 90 per cent length of pygidium, composed of 20 rings; first six rings continuous, subsequent rings becoming discontinuous mesially. Ring furrows successively shallower toward back. Axial furrow deep and broad anteriorly, becoming narrower and shallower posteriorly. Pleural lobe weakly convex to midwidth, downcurved abaxially. Ten pleural ribs; tenth rib postaxial, with tip generally bluntly fused with ninth; ribs flat topped, widening steadily; tips of ribs pointed and outturned, more bluntly so posteriorly. Ribs successively directed increasingly backward and outward, tenth parallel. Rib furrows deep and broad, widening slightly abaxially. Anterior band of first pleura with clear articulating facet. Four congruent axial and pleural segments. Ventral border uniformly narrow; inner margin straight; junction evenly rounded, unembayed.

Surface of cephalon, except on occipital segment and in furrows, closely tuberculate; tubercles of mixed sizes, diameter of largest being 8 per cent maximum width of frontal lobe; about one hundred tubercles on adult glabella, many perforate. A quincunx of small tubercles composed of L1-1; S1-0; L2-1. Remainder of tubercles randomly distributed. Occipital segment finely and sparsely granular. A single row of tubercles on anterior border of cranidium. Tubercles on genae larger adaxially. Pygidium granular; three or four small median tubercles on axis of pygidium randomly spaced. Attribute coding (Temple and Tripp, 1979): 1-0; 2-20; 3-0; $4-1 ; 5-1 ; 6-10 ; 7-0 ; 8-1 ; 9-4 ; 10-1 ; 11-1 / 2 ; 12-1 ; 13-1 ; 14-$ $1 ; 15-0 ; 16-1 ; 17-0 ; 18-0 ; 19-0 ; 20-0 ; 21-1 ; 22-1 ; 23-0 ; 24-$ 
$0 ; 25-1 ; 26-0 ; 27-100 ; 28-12 ; 29-0 ; 30-2.5 ; 31-0 ; 32-1 ; 33-$ $8 ; 34-0$.

Small pygidia have fewer segments and more strongly developed ring furrows. On one pygidium, $3 \mathrm{~mm}$ in sagittal length (Pl. 10, fig. 5), ninth and tenth rings bifurcate laterally, third and fourth right ribs fused abaxially.

\section{DISCUSSION}

The holotype of Encrinunus moderatus Poulsen (1934:31, pl. 3, fig. 20), from the Cape Schuchert Formation, St. George Fiord, North Greenland, is a small cranidium, $5.0 \mathrm{~mm}$ in length, attributable to Cromus princeps; thus moderatus is a junior subjective synonym of princeps. The two pygidia from the same horizon and locality referred to E. moderatus by Poulsen (1934, pl. 3 , figs. 21,22 ) are not attributable to Cromus; they are distinct from the pygidium from Cape Constitution named Encrinumis inflatus by Poulsen (1934, pl. 3, fig. 19).

C. princeps most closely resembles $C$. novaki (Frech, 1888:735, pl. 29, figs. 5-9), from beds of Middle Silurian age in the Carnic Alps; $C$. novaki also possesses an anteromedian furrow and short genal spines. $C$. princeps differs in that the eyes are placed farther back and the tuberculation is coarser.

\section{Genus Encrinuraspis Webby, Moors, and McLean, 1970}

\section{TYPE SPECIES}

Encrinuraspis optimus Webby, Moors, and McLean, 1970, Malongulli Formation (?Caradoc Series), New South Wales, Australia.

\section{Encrinuraspis sp.}

Pl. 9, fig. 6

\section{MATERIAL}

From BB 131 (Lower Silurian), Illtyd Range: 1 pygidium.

\section{DESCRIPTION}

Pygidium 70 per cent as long as wide, moderately and evenly convex. Axis 30 per cent anterior width and 80 per cent length, tapering to a point. Twelve rings, of which first six continuous; a longitudinal median depression as deep as ring furrows interrupting posterior rings. Large median tubercles on fourth, sixth, and eighth rings. Pleural lobe downcurved with seven ribs widening slightly and a broad postaxial ridge comprising fused eighth ribs. Ring-to-pleura ratio 1.7. Two congruent axial and pleural segments. Apart from the four axial tubercles, prosopon greatly subdued.

\section{DISCUSSION}

This pygidium has much in common with Balizomathe low number of rings and pleurae, large axial tubercles, and longitudinal axial furrow-but must be excluded from Balizoma under Ramsköld's (1986) definition on account of the high ring-to-pleura ratio. Furthermore, the pleural area is not strongly downturned, and the pleural ribs are narrow and without large tubercles.

Šnajdr (1985) reestablished Encrinuraspis Webby, Moors, and McLean (1970), considered by Strusz (1980) as a junior synonym of Cromus. The case for retention is disputable, but Encrinuraspis may prove to be a useful taxon for species not readily attributable elsewhere, and the llltyd Range pygidium is a case in question.

\section{Genus Balizoma Holloway, 1980}

\section{TYPE SPECIES}

Calymene variolaris Brongniart, 1822, Much Wenlock Limestone Formation, Dudley, West Midlands, United Kingdom.

\section{Balizoma aff. B. obtusus (Angelin, 1851) \\ Pl. 11, figs. 8-10,12-18}

\section{MATERIAL}

From AA 95 (Upper Silurian), Prongs Creek: 5 cranidia, 1 librigena, 1 hypostome, 27 pygidia.

\section{DESCRIPTION}

Glabella 90 per cent as wide as long, with width across L2 60 per cent width across frontal lobe, moderately rounded in outline, uniformly convex longitudinally and transversely. Occipital ring short (sag.), wider than base of preoccipital glabella, strongly arched transversely; occipital furrow deep and broad. Frontal lobe 45 per cent sagittal length of glabella. L1 and S1 almost obsolete. L2 and L3 represented by comparatively small nodular tubercles. S2 and S3 short, broad, shallow furrows, discontinuous mesially. Axial furrow deep and broad, with fossula near front. Preglabellar furrow shallow. Eleven moderately sized tubercles on anterior border of cranidium; lateral tubercle not enlarged. Fixigena convex. Posterior border short (sag.), incomplete; posterior border furrow deep and broad. Genal angle unknown. Cranidium finely and densely tuberculate; larger tubercles perforate. Basal diameter of wid- 
est glabellar tubercles 10 per cent maximum width of glabella across L4; a pair of larger tubercles opposite L2; remaining tubercles not clearly symmetrically arranged; total number about 60 . A single row of small tubercles on occipital ring and posterior border.

Librigena incompletely known, with comparatively small field and broad lateral border. Rostral plate unknown.

Hypostome rhombic, with width (excluding anterior wings) 75 per cent length and anterior margin narrowly rounded. Middle body inflated, well defined by strong lateral furrow. Rhynchos large, projecting somewhat anterior to middle body, widening slightly backward, and dying out near midlength of middle body. Macula small but distinct. Anterior border short. Anterior wing large, sloping obliquely upward. Lateral border narrow, depressed. Posterior tongue almost 20 per cent length of hypostome, horizontally extended. Surface of middle body granular, with a few pits and folds.

Pygidium triangular in outline, strongly convex in both directions, high in profile, with width 85 to 95 per cent length (average width-to-length ratio 1.1:1). Axis 35 per cent maximum width of pygidium, strongly convex transversely, with 13 rings and a terminus; postaxial ridge short, reaching posterior margin in a few specimens. Rings continuous. Sagittal groove lacking on external moulds, shallower than ring furrows alongside tubercles on internal moulds. Ring furrows broad and deep. Sagittal tubercles only slightly larger than abaxial ring tubercles, absent on first and second rings, frequently on successive rings toward back. Axial furrow deep anteriorly, becoming weaker posteriorly. Nine strong pleural ribs; tenth pair short and joined at tips, or fused in a postaxial ridge; ribs parallel sided, directed increasingly strongly backward, curving downward at fulcrum. Four or five small tubercles on each pleural rib. Tips of ribs projecting in short free points. Four rings and pleurae congruent. Rib furrows deep and broad throughout. Ring-to-pleura ratio (R/P) as defined by Ramsköld (1986:529) 1.2-1.3.

\section{DISCUSSION}

It is Ramsköld's opinion (pers. comm., 1987) that this material falls within the range of the abundant Swedish species B. obtusus (Angelin, 1851:3, pl. 4, fig. 9; see Ramsköld, 1986:561, pl. 40, fig. 2; pl. 48, figs. 1-14; pl. 49, figs. 1-10), from the Mulde Beds (Middle Silurian), Klinteberg Marl, Hemse Beds, and Eke Beds (Upper Silurian), Gotland, Sweden. Ramsköld recognized three morphological forms: Form A, the "type form," restricted to the northeastern limestone areas in the Hemse Beds and the Eke Beds at Lau Backar; Form
B, restricted to the "marl" west and south of the southwestern outcrops of the Hemse Beds limestone area; and Form $\mathrm{C}$, known only from pygidia from the upper Eke Beds. The hypostome from AA 95 is similar in main characters to that of B. obtusus (Ramsköld, 1986, pl. 48 , fig. 1) but differs in having a less strongly defined, unwaisted rhynchos; in size, it is appropriate to $B$. aff. B. obtusus, but it should possibly be attributed to the indeterminate encrinurine described below. The pygidia under description most closely resemble $B$. obtusus Form B, but differ in the width-to-length proportions85 to 95 per cent for Road River Formation specimens, compared to 65 to 85 per cent for B. obtusus Form B.

Ramsköld (1986:66) has discussed the possibility that B. rosensteinae (Tripp, Temple, and Gass, 1977:860, pl. 115, figs. 1-13), from the Ludlow Series, United Kingdom, and $B$. dimitrovi Perry and Chatterton (1979:589, pl. 72, figs. 1-3; pl. 73, figs. 1-17,29-31; pl. 74, figs. 1-14,18-23,30-35), from the upper Whittaker and lower Delorme formations (Wenlock to lower Ludlow), Delorme Range, Mackenzie Mountains, Canada, are synonymous with B. obtusus. Ramsköld (1986:561) has restricted the genus Balizoma to species with a ring-to-pleura ratio (R/P) of 1.1-1.4, thus excluding the two Bohemian species of Pridoli age Encrinuraspis? subvariolaris concomitans Přibyl and Vaněk, 1962, and Encrinuraspis? testosteron Šnajdr, 1981, which have higher ring-to-pleura ratios $(\mathrm{R} / \mathrm{P})$ of 1.6 and 1.8 , respectively.

\section{Indeterminate encrinurine}

Pl. 11, fig. 11

\section{MATERIAL}

From AA 95 (Upper Silurian), Prongs Creek: 1 cranidium.

\section{DISCUSSION}

This single cranidium differs considerably from that of Balizoma aff. B. obtusus and of most other species of Balizoma in the following features: (1) twice as large; (2) glabella narrowing more strongly backward; (3) smaller, multituberculate lateral lobes; (4) tubercles on glabella and anterior border of cranidium double in number and much smaller in size; (5) smaller tubercles adaxially on fixigena. Balizoma is the genus that this cranidium most closely resembles, but the small tubercles and lateral glabellar lobes exclude this cranidium from that genus as currently understood. The lateral lobes are completely unlike Cromus, and the shape of the cranidium and features of the prosopon are unlike Encrinuraspis. 
Indeterminate calymenid

PI. 9, fig. 7

\section{MATERIAL}

From BB 131 (Lower Silurian), Illtyd Range: 1

pygidium.

\section{DESCRIPTION}

Length 65 per cent width; convexity strong. Axis 35 per cent anterior width, 95 per cent length of pygidium, narrowing steadily backward to broadly rounded tip, composed of eight rings and a terminus. Ring furrows deep and broad anteriorly, becoming successively weaker toward back. Articulating half-ring and furrow well developed. Axial furrow deep, increasing in width toward back. Pleural lobe evenly convex; four strongly developed, flat-topped ribs curving outward and backward; fifth rib flanking axial furrow and directed backward. Interpleural furrows weak, dying out adaxially; pleural furrows strong. Articulating half pleura strong adaxially. Surface smooth.

\section{DISCUSSION}

It is impossible to assign this single pygidium to a genus or subfamily.

\section{Family Lichidae Hawle and Corda, 1847 \\ Subfamily Lichinae Hawle and Corda, 1847}

\section{Genus Dicranopeltis Beyrich, 1845}

\section{TYPE SPECIES}

Lichas Scabra Beyrich, 1845, Liten Formation (Upper Silurian), Prague district, Czechoslovakia.

\section{Dicranopeltis sp.}

Pl. 10, figs. 10-12

\section{MATERIAL}

From BB 131 (Lower Silurian), 1lltyd Range: 1 cranidium, 1 pygidium.

\section{DESCRIPTION}

Cranidium strongly convex in both directions. Occipital ring incomplete. Occipital furrow as deep as axial furrow. Median lobe narrowing slowly and steadily backward to about 50 per cent anterior width when opposite $\mathrm{S} 1$, and then expanding posteriorly; preoccipital depression connecting inner extremities of S1. Bullar lobe half length of cranidium, with strong independent convexity. L1 and fixigena fused. Basal glabellar lobe absent. Longitudinal furrow deep and narrow. Axial furrow continuous with S1, curving gently inward to longitudinal furrow.

Pygidium 65 per cent as long as wide. Axis strongly convex, 30 per cent anterior width, narrowing steadily backward, not pointed; three rings and furrows continuous across axis; a swollen terminus sloping downward and backward to depressed tip of axis. Axial furrows deep and narrow anteriorly, becoming shallow posteriorly, convergent. Pleural lobe flattened; three pairs of furrowed pleurae ending in short, free points. Doublure gently convex; terrace ridges strong.

Prosopon tuberculate, coarser on pygidium than on cranidium.

\section{DISCUSSION}

The cranidium resembles that of the type species $D$. scabra (Beyrich; see Barrande, 1852, pl. 28, figs. 22-26) in conformation and in the presence of the preoccipital furrow, but differs in the absence of basal glabellar lobes. The pygidium is distinctive in its long, swollen, and strongly segmented axis.

\section{Subfamily uncertain}

Indeterminate lichid

Pl. 7, figs. 16-20

\section{MATERIAL}

From AA 95 (Upper Silurian), Prongs Creek: 3 cranidia, 2 hypostomes, 5 pygidia.

\section{DISCUSSION}

This lichid material is too sparse to justify formal description. The two incomplete cranidia illustrated are similar in gross morphology, but have different prosopon features and slight differences in convexity of lobes and in courses of furrows; in both cranidia, the 
longitudinal furrow is continuous anteriorly, and it is unknown whether a basal glabellar lobe was present or not. The specimens appear to belong to the subfamily Trochurinae $(=$ Ceratarginae, see Thomas and Holloway, 1988). The two hypostomes would unhesitatingly be referred to the subfamily Trochurinae on account of the broad, unembayed posterior border and circumscribed middle body. All the pygidia are remarkable in that they resemble Amphilichas (subfamily Tetralichinae, recorded only from the Ordovician System) in the pointed axis and absence of pleural furrows on the third pleurae; there is a small median embayment in the posterior margin, but no extended free point to the third pleura. These pygidia differ conspicuously from those of the Trochurinae in outline, in having an unswollen posterior band, and in the absence of a lateral border. At first sight, therefore, the pygidia belong to a different subfamily from that of the cranidia and hypostomes.

A comparable conflict arises regarding the lichid described as Dicranogmus skinneri by Perry and Chatterton (1977:308, pl. 6, figs. 16-21), from Cape Phillips Formation (Middle Silurian), Baillie-Hamilton Island, Canadian Arctic Archipelago. The cranidium of this species closely resembles that of the trochurine Dicranogmus pustulatus Hawle and Corda (1847:146, pl. 7 , fig. 77a,b), the type species, from the Upper Silurian, Czechoslovakia, the hypostome and pygidium of which are unknown. The hypostome of $D$. skinneri is trochurine also. The pygidium is Amphilichas-like in its pointed axis and unfurrowed, flattened third pleurae. The original grounds for associating the parts, based on occurrence and particularly on the prosopon, are convincing.

Although the Prongs Creek and the Baillie-Hamilton Island specimens are dissimilar in many respects, these two enigmatic associations in northern Canada are unlikely to be coincidental. The Tetralichinae and Trochurinae are sister subfamilies, and it may be that a rootstock persisted in this area into the Silurian Period.

Subfamilies of the Lichidae are consistent in the morphology and comparative anatomy of the parts with the exception of the above examples and another surprising anomaly in the Cape Phillips Formation. This is the form described as Lichid n. gen., n. sp. (subfamily Ceratarginae) by Perry and Chatterton (1977:303, pl. 7, figs. 1-9), in which pygidia of Radiolichas type are associated with inappropriate cranidia.

Family Odontopleuridae Burmeister, 1843

Subfamily Odontopleurinae Burmeister, 1843

\section{Genus Leonaspis Richter and Richter, 1917}

\section{TYPE SPECIES}

Odontopleura leonhardi Barrande, 1846, Kopanina Formation (Upper Silurian), Prague district, Czechoslovakia.

\section{Leonaspis semiglabra (Poulsen, 1934)}

Pl. 12, figs. 1-13; Pl. 13, figs. 13,14; Text-fig. 5D

Ceratocephala (sens. lat.) groenlandica Poulsen, 1934:24, pl. 3, fig. 5 (non figs. 6,7).

Ceratocephala (Leonaspis?) semiglabra Poulsen, 1934:25, pl. 3, fig. 8 (non fig. 9 = groenlandica).

Leonaspis semiglabra - Raasch in Raasch, Norford, and Wilson, 1961:474, fig. 4.10-18.

Scutellum borealis-Raasch in Raasch, Norford, and Wilson, 1961:474, fig. 5.9 (non figs. 6-8).

\section{HOLOTYPE}

MMH 3261 (cranidium, figured by Poulsen, 1934, pl. 3, fig. 8; in this paper, Pl. 13, fig. 13), Cape Schuchert Formation (Lower Silurian), Kap Schuchert, North Greenland.

\section{MATERIAL}

From AA 2-4.5 (Lower Silurian), Prongs Creek: 1 dorsal shield, 8 cranidia, librigenae, 4 hypostomes, 11 pygidia.

\section{DESCRIPTION}

Cranidium 25 per cent length of dorsal shield, 60 per cent as long as wide, moderately convex. Glabella 80 to 85 per cent as wide as long. Occipital ring 20 per cent length of cranidium, without lobes or spines; occipital tubercle somewhat enlarged. Central lobe well defined by strong independent convexity, subparallel sided but constricted opposite L1 and L2, expanding anteriorly; frontal lobe, where broadly rounded, 60 per cent width across $\mathrm{L} 1$. L1 rounded, swollen, 30 per cent basal width of glabella. S1 deep, oblique, widening at apodeme at extremity, shallow at back. L2 elongatedly ovate, swollen, 25 per cent glabellar width, circumscribed. S2 oblique, apodeme at extremity, thence running backward, shallowing at S1. L3 and S3 absent. Axial furrows strongly divergent backward, comparatively shallow. Anterior border uniformly short, transverse. Fixigena 15 per cent width of cranidium, narrowing steadily forward, gently convex. Eye ridge narrow (tr.), extending almost to posterior border furrow. 
Librigena sloping outward. Eye sessile, posteriorly placed. Field broad, gently convex. Lateral border 20 per cent minimum width of field, widening backward. Lateral border furrow shallow. Genal spine curving backward and outward, extending as far as seventh thoracic segment. Seventeen or more outwardly directed lateral spines, hindmost on genal spine; anterior few spines shorter than width of border, squat, and blunt; subsequent spines longer than width of border and successively longer, slender, and pointed. Doublure smooth, extending to lateral border furrow.

Hypostome subquadrate, squat, slightly wider than long. Middle body subquadrate, gently swollen, extending to anterior margin. Middle furrow short, oblique. Lateral lobe half length of middle body abaxially, narrow. Lateral border narrow, convex, widening and less swollen posterior to midlength; posterior wings project strongly, situated 60 per cent length from front. Lateral furrow very shallow alongside lateral lobe, broad and well defined posteriorly. Posterior border essentially transverse but bowed backward mesially, weakly convex.

Thorax 55 per cent length of dorsal shield; nine thoracic segments on disarticulated dorsal shield. Axis 30 per cent anterior width of thorax, arched transversely; lateral nodes well developed. Axial furrow shallow and broad. Pleura horizontal, comprising a short (exsag.), slightly swollen anterior band separated by a broad, shallow furrow from longer (exsag.) and much more swollen posterior band; posterior band terminating in a long, slender spine. Spines successively longer and more backwardly directed. A row of granules on posterior margin of rings; posterior bands of pleurae weakly granular.

Pygidium, excluding spines, 30 to 35 per cent as long as wide. First ring and furrow strong. Second ring almost equally swollen; ring furrow dying out abaxially. Third ring stunted; posterior margin bowed backward. Axial furrow shallow alongside first ring, deep and broad posteriorly. Pleural lobe largely occupied by swollen rib running obliquely from opposite first ring to great spine. Lateral border widening backward, faintly developed at great spine. Five pairs of spines: foremost pair small; second and third pairs gradational in length to fourth pair (great spines); fourth pair twice sagittal length of pygidium; fifth pair as long as third pair.

Prosopon consisting of tubercles of various sizes; a single row of tubercles on anterior border and eye ridge.

\section{DISCUSSION}

The holotype cranidium of L. semiglabra (Poulsen) is incomplete posteriorly, and it is not possible to be certain whether occipital spines were present or not. The Road River Formation cranidia agree in other features, and we follow Raasch in Raasch, Norford, and Wilson (1961) in considering these cranidia conspecific with the $L$. semiglabra holotype. The holotype cranidium of L. groenlandica (Poulsen, 1934:24, pl. 3, fig. 6), also from Kap Schuchert, differs markedly from $L$. semiglabra in its rounded anterior margin and broader fixigena. Only one form of the various odontopleurid skeletal elements is present in the Road River Formation material, indicating a single species. The librigena attributed to L. groenlandica by Poulsen (1934, pl. 3, fig. 5; this paper, Pl. 13, fig. 14) corresponds to our material; it differs from the one referred to semiglabra by Poulsen (1934, pl. 3, fig. 9) in its narrower border and denser tuberculation.

\section{Indeterminate odontopleurine}

Pl. 10, fig. 9

MATERIAL

From BB 131 (Lower Silurian), Illtyd Range: 1 cranidium.

\section{DISCUSSION}

This cranidium differs from the cranidia attributed to L. semiglabra in having a more parallel-sided median glabellar lobe, a more convex frontal lobe, coarser tuberculation, and a nontuberculate adaxial portion of the fixigena. Although this specimen is probably attributable to Leonaspis, the generic reference is best left undecided. 


\section{Acknowledgements}

We thank Bob Owens, Alan Thomas, and Lars Ramsköld for information and opinions on some of these trilobites. Valdemar Poulsen of the University of Copenhagen kindly provided plaster casts of C. Poulsen's trilobite types from North Greenland. We thank Godfrey Nowlan of the Geological Survey of Canada for identification of the conodont faunas. Brian
O'Donovan printed the trilobite photographs from our negatives. The figures were prepared by David Sargent and Ilgvars Steins. David Rudkin, Janet Waddington, and Joan Burke of the Royal Ontario Museum were very helpful with a variety of palaeontological, curatorial, and editorial matters. This project was supported by NSERC Operating Grant A3825 to Rolf Ludvigsen. 


\section{Literature Cited}

ANGELIN, N. P.

1851 Palaeontologia Svecicae. I: Iconographia crustaceorum formationis transitionis. Holmiae. Fasc. 1:1-24.

1854 Palaeontologia Scandinavica. I: Crustacea formationis transitionis. Academiac Regiae Scientarium Suecanae, Holmiae, pp. 21-92.

BARRANDE, J.

1846 Notice préliminaire sur le Systême Trilobites de Bohême. Leipsig. 97 pp.

1852 Systême Silurien du centre de la Bohême. lère partie. Recherches paléontologiques, vol. 1. Crustacés. Trilobites. Prague et Paris. 935 pp.

BEYRICH, E.

1845 Ueber einige böhmische Trilobiten. Berlin. 47 pp. BOUČEK, B.

1933 O nových trilobitech českého gotlandienu. Cást I. Věstnik Státigraphi geologisch Ústredniho 9:171179.

BOLTON, T. E.

1965 Trilobites from the Upper Silurian rocks of the Canadian Arctic Archipelago: Encrinurus (Frammia) and Hemiarges. Geological Survey of Canada, Bulletin 134:1-14.

BRONGNIART, A

1822 Les Trilobites. In Brongniart, A. and A. G. Desmarest, Histoire naturelle des crustacés fossiles, sous les rapports zoologiques et géologiques. Paris and Strasbourg, F. G. Leverault. 154 pp.

BURMEISTER, $\mathrm{H}$

1843 Die Organisation der Trilobiten. Berlin, Georg Reimer. $147 \mathrm{pp}$.

CHANG, W.

1974 Silurian Trilobita. In A handbook of the stratigraphy and palaeontology in southwest China. Beijing, Academic and Science Press. 454 pp.

CHATTERTON, B. D. E

1971 Taxonomy and ontogeny of Siluro-Devonian trilobites from near Yass, New South Wales. Palaeontographica (Abt. A) 137:1-108.

CHATTERTON, B. D. E. and K. S. W. CAMPBELL

1980 Silurian trilobites from near Canberra and some related forms from the Yass Basin. Palacontographica (Abt. A) 167:77-119.

CHATTERTON, B. D. E. and R. LUDVIGSEN

1976 Silicified Middle Ordovician trilobites from the South Nahanni River area, District of Mackenzie, Canada. Palacontographica (Abt. A) 154:1-106.

CHATTERTON, B. D. E. and D. PERRY

1977 Lochkovian trilobites and conodonts from northwestern Canada. Journal of Paleontology 51:772796.

1983 Silicified Silurian odontopleurid trilobites from the Mackenzie Mountains. Palaeontographica Canadiana 1:1-126.
DAWES, P. R. and J. HALLER

1979 Historical aspects in the geological investigation of northern Greenland. Part 1. New maps and photographs from the 2nd Thule Expedition 1916-1918 and the Bicentenary Jubilee Expedition 1920-1923. Meddelelser om Grønland 200:138.

FEIST, $R$.

1970 Breviscutellum (Meridioscutellum) n. sg. (Trilobite) et son développement larvaire. Geobios 3(Fasc. 4):41-73.

FRECH, F. F.

1888 Über das Devon der Ostalen. Deutsche geologische Gesellschaft, Zeitschrift 39:659-738.

FRITZ, W. H.

1985 The basal contact of the Road River Group-a proposal for its location in the type area and in other selected areas in the northern Canadian Cordillera. Geological Survey of Canada, Paper 85-1B:205-215.

HAWLE, I. and A. J. C. CORDA

1847 Prodrom einer Monographie der böhmischen Trilobiten. Prague. $176 \mathrm{pp}$.

HEDSTRÖM, $\mathrm{H}$.

1923 Contributions to the fossil fauna of Gotland. Sveriges Geologiska Undersökning 316:3-15.

HELBERT, G. J., P. D. LANE, R. M. OWENS, D. J. SIVETER, and A. T. THOMAS

1982 Lower Silurian trilobites from the Oslo Region. IUGS Subcommission on Silurian stratigraphy, Ficld Meeting, Oslo Region 1982. In Worsley, D., ed., Palaeontological Contributions from the University of Oslo 178:129-148.

HOLLOWAY, D. J.

1980 Middle Silurian trilobites from Arkansas and Oklahoma, U.S.A. Palaeontographica (Abt. A) 170:1-85.

HOLM, G.

1882 De Svenska arterna af Trilobitsläktet Illaenus (Dalman). Kunglige Svenska Vetenskapsakademiens, Bihang till Handlingar 7:1-148.

1886 Revision der ostbaltischen silurischen Trilobiten. Abtheilung 3. Illaeniden. Mémoires de l'Académie impériale des sciences de St.-Pétersbourg $33: 1-173$.

HURST, J. M.

1980 Silurian stratigraphy and facies distribution in Washington Land and western Hall Land, North Greenland. Grønlands Geologiske Undersøgelse, Bulletin 138:1-95.

JACKSON, D. E., A. C. LENZ, and A. E. H. PEDDER

1978 Late Silurian and Early Devonian graptolite, brachiopod and coral faunas from northwestern and arctic Canada. Geological Association of Canada, Special Paper 17:1-159. 
KOBAYASIII, T.

1985 On two Silurian trilobite genera, Prantlia and Latiproetus. Proceedings of the Japan Academy, Series B: Physical and Biological Sciences 61:419 421.

KOBAYASH, T. and T. HAMADA

1974 Silurian trilobites of Japan in comparison with Asian, Pacific and other faunas. Palacontological Society of Japan, Special Paper 18:1-155.

I.AMONT, A.

1948 Scottish dragons. Quarry Managers' Journal 31:531-535.

IANE, P. D.

1972 Ncw trilobites from the Silurian of north-east Greenland, with a note on trilobite faunas in pure limestones. Palaeontology 15:336-364.

1979 Llandovery trilobites from Washington Land, North Greenland. Grønlands Geologiske Undersøgelse, Bulletin 131:1-37.

1984 Silurian trilobites from Hall Land and Nyeboe Land, western Greenland. Grønlands Geologiske Undersøgelse, Rapport 121:53-75.

1988 Silurian trilobites from Peary Land, central North Greenland. Grønlands Geologiske Undersøgelse, Rapport 137:93-117.

LANE, P. D. and R. M. OWENS

1982 Silurian trilobites from Kap Schuchert, Washington Land, western North Greenland. Grønlands Geologiske Undersøgelse, Rapport 108:41-69.

LANE, P. D. and A. T. THOMAS

1983 A review of the trilobite suborder Scutelluina. Special Papers in Palaeontology 30:141-160.

LENZ, A. C

1970 Late Silurian brachiopods of Prongs Creek, northern Yukon. Journal of Paleontology 44:480 500.

1972 Ordovician and Devonian history of northern Yukon and adjacent District of Mackenzie. Bulletin of Canadian Petroleum Geology 20:321-361.

1976 Late Ordovician-Early Silurian glaciation and the Ordovician-Silurian boundary in the northern Canadian Cordillera. Geology 4:313-317.

1977 Upper Silurian and Lower Devonian brachiopods of Royal Creek, Yukon, Canada. Palacontographica (Abt. A) 159:37-138.

1979 Llandoverian graptolite zonation in the northern Canadian Cordillera. Acta Palaeontologica Polonica 24:137-153.

1982 Llandoverian graptolites of the northern Canadian Cordillera: Petalograptus, Cephalograptus, Rhaphidograptus, Dimorphograptus, Retiolitidae, and Monograptidae. Royal Ontario Museum, Life Sciences Contributions 130:1-154.

LENZ, A. C. and A. E. H. PEDDER

1972 Lower and Middle Paleozoic sediments and paleontology of Royal Creek and Peel River, Yukon, and Powell Creek, N.W.T. 24th International Geological Congress, Montreal, Guidebook to Field Excursion A 1:1-43.
L.INDSTRÖM, G.

1885 Förteckning på Gotlands siluriska crustacéer. Kunglige Svenska Vetenskapsakademiens, Öfversigt Handlingar 34:1-89.

LU, Y.-H.

1962 Restudy on Grabau's threc Silurian trilobites from Hupeh. Acta Palaeontologia Sinica 10:158173

LUDVIGSEN, R., S. R. WESTROP, B. R. PRATT, P. A. TUFFNELL, and G. R. YOUNG

1986 Paleoscene \#3. Dual biostratigraphy: zones and biofacies. Gcoscience Canada 13:139-154.

MIKULIC, D. G.

1981 Trilobites in Paleozoic carbonate buildups. Lethaia $14: 45-56$.

MILNE-EDWARDS, $\mathrm{H}$.

1840 Histoire naturelle des crustacés, comprenant l'anatomie, la physiologie et la classification de ces animaux. Paris. $638 \mathrm{pp}$.

MOORE, R. C.

1959 Treatise on invertebrate paleontology. Part 0. Arthropoda 1. Lawrence, Geological Society of America and University of Kansas Press. 560 pp. NORFORD, B. S.

1962 lllustrations of Canadian fossils: Cambrian, Ordovician and Silurian of the western Cordillera. Geological Survey of Canada, Paper 62$14: 1-25$.

1964 Reconnaissance of the Ordovician and Silurian rocks of northern Yukon Territory. Geological Survey of Canada, Paper 63-39:1-139.

1972 Silurian stratigraphic sections at Kap Tyson, Offley $\varnothing$, and Kap Schuchert, northwestern Greenland. Meddelelser om Grønland 195:1-40.

1973 Lower Silurian species of the trilobite Scotoharpes from Canada and northeastern Greenland. Geological Survey of Canada, Bulletin 222:9-33.

1981 The trilobite fauna of the Silurian Attawapiskat Formation, northern Ontario and northern Manitoba. Geological Survey of Canada, Bulletin 327:1-37.

NORFORD, B. S., T. E. BOLTON, M. J. COPELAND, L. M. CUMMING, and G. W. SINCLAIR

1970 Ordovician and Silurian faunas. In Douglas, R. J. W., ed., Geology and economic minerals of Canada. Geological Survey of Canada, Economic Geology Report 1:601-613.

NORRIS, A. W.

1985 Stratigraphy of Devonian outcrop belts in northern Yukon Territory and northwestern District of Mackenzie (Operation Porcupine area). Geological Survey of Canada, Memoir 410:1-81.

OSMÓLSKA, H.

1970 Revision of non-cyrtosymbolinid trilobites from the Tournasian-Namurian of Eurasia. Palaeontologia Polonica 23:1-165.

OWENS, R. M.

1973 British Ordovician and Silurian Proetidae (Trilobita). Palaeontographical Society Monograph. 
London, Palaeontographical Society. 98 pp.

PERRY, D. and B. D. E. CHATTERTON

1977 Silurian (Wenlockian) trilobites from BaillieHamilton Island, Canadian Arctic Archipelago. Canadian Journal of Earth Sciences 14:285-317.

1979 Wenlock trilobites and brachiopods from the Mackenzie Mountains, north-western Canada. Palaeontology 22:569-607.

POULSEN, C.

1934 The Silurian faunas of North Greenland. 1. The fauna of the Cape Schuchert Formation. Meddelelser om Grønland 72:1-46.

PŘIBYL, A.

1946 O několika nových trilobitových rodech z českého siluru a devonu. Príroda 38:1-7.

PŘIBYL, A. and J. VANĚK

1962 Trilobitová fauna českého svrchniho siluru (budňanu a lochkovu) a jeji biostratigrafický význam. Sborník Národního Muzea v Praze 18:25-46.

1978 Studie zu einiger neuen Trilobiten der ProetidaeFamilie. Acta Universiteatis Carolinae-Geolica 1-2:163-182.

QIU, H., Y. LU, Z. ZHU, D. BI, T. LIN. Z. ZHOU, Q. ZHANG, Y. QIAN T. JU, N. HAN, and X. WEI

1983 Trilobita. In Palacontological Atlas of East China. Beijing, Geological Publishing House, pp. 28-254. [In Chinese]

RAASCH, G. O., B. S. NORFORD, and D. W. R. WILSON

1961 The Silurian Aulacopleura Socialis in the Yukon Territory. In Raasch, G. O., ed., Geology of the Arctic. Toronto, University of Toronto Press, vol. 1, pp. 466-480.

RAMSKÖLD, L.

1986 Silurian encrinurid trilobites from Gotland and Dalarna, Sweden. Palacontology 29:527-575.

RAYMOND, P. E.

1916 New and old Silurian trilobites from southeastern Wisconsin, with notes on the genera of the Illaenidae. Harvard Museum of Comparative Zoology, Bulletin 60:1-41.

RICHTER, R, and E. RICHTER

1917 Über die Einteilung der Familie Acidaspidae und über einige ihrer devonischen Vertreter. Zentralblatt für Mineralogie, Geologie und Paläontologie, pp. 462-472.

1955 Scutelluidae n.n. (Tril.). Senckenbergiana lethaca $36: 291-293$.

SALTER, J. W.

1864 A monograph of the British trilobites from the Cambrian, Silurian, and Devonian formations. Palacontographical Society Monograph. London, Palaeontographical Society. 80 pp.

S̊NAJDR, M.

1958 Několik nových rodů trilobitů z čcledě Scutelluidae. Věstnik Ústředního ústavu geologického 33:1-263.

1960 A study of the Family Scutelluidae (Trilobitae).
Rozpravy Ústředního ústavu geologického 26:11221.

1980 Bohemian Silurian and Devonian Proetidac (Trilobita). Rozpravy Ústředního ústavu geologického 45:1-323.

1981 New Silurian and Devonian trilobites (Barrandian, Czechoslovakia). Věstnik Ústředního ústavu geologického 56:301-303.

1985 Bohemian representatives of the subfamily Encrinurinae, Trilobita. Sborník Geologických Věd Paleontologie 27:9-46.

STRUSZ, D. L.

1980 The Encrinuridae and related trilobite families, with a description of Silurian species from southeastern Australia. Palaeontographica (Abt. A) 168:1-68.

TEMPLE, J. T. and R. P. TRIPP

1979 An investigation of the Encrinuridae (Trilobita) by numerical taxonomic methods. Transactions of the Royal Society of Edinburgh 70:223-250.

THOMAS, A. T.

1978 British Wenlock trilobites. Part 1. Palaeontographical Society Monograph. London, Palaeontographical Society. $56 \mathrm{pp}$.

1979 Trilobite associations in the British Wenlock. Geological Society of London, Special Publication 8:447-452.

THOMAS, A. T. and D. J. HOLLOWAY

1988 Classification and phylogeny of the trilobite order Lichida. Philosophical Transactions of the Royal Society of London, Series B 321:179-262.

THOMAS, A. T. and G. M. NARBONNE

1979 Silurian trilobites from arctic Canada. Geological Magazine 116:1-19.

THOMAS, A. T. and R. M. OWENS

1978 A review of the trilobite family Aulacopleuridae. Palaeontology 21:65-81.

TRIPP, R. P., J. T. TEMPLE, and K. C. GASS

1977 The Silurian trilobite Encrinurus variolaris and allied species, with notes on Frammia. Palaeontology 20:847-867.

VOGDES, A. W.

1890 A bibliography of Palaeozoic Crustacea from 1698 to 1889 including a list of North American species and a systematic arrangement of genera. United States Geological Survey, Bulletin 63:1177.

WEBBY, B. D., H. T. MOORS, and R. A. McLEAN

1970 Malongullia and Encrinuraspis, new Ordovician trilobites from New South Wales, Australia. Journal of Paleontology 44:881-887.

WESTROP, S. R.

1983 The life habits of the Ordovician illaenine trilobite Bumastoides. Lethaia 16:15-24.

WHITTINGTON, H. B.

1959 Silicified Middle Ordovician trilobites: Remopleurididac, Trinucleidac, Raphiophoridac, 
Endymioniidae. Harvard Museum of Comparative Zoology, Bulletin 121:371-496.

WU, H.

1977 Comments on new genera and species of SilurianDevonian trilobites in southwest China and their significance. Acta Palaeontologia Sinica 16:95117.
ZENKER, J. C.

1833 Beiträge zur Naturgeschichte der Urwelt. Organische Reste (Petrefecten) aus der Altenburger Braunkohlen-Formation dem Blankenburger Quadersandstein, jenaischen bunten Sandstein und böhmischen Uetergangsgebirge. Jena. 67 pp. 
Plate 1, figs. 1-15.

Paracybantyx asulcatus gen. et sp. nov., locality AA 95, Road River Formation, Prongs Creek, Yukon Territory, Canada.

1-3. Cranidium, dorsal, frontal, and oblique views, ROM 45343, $\times 2$.

4,5. Holotype cranidium, lateral and dorsal views, ROM 45344, $\times 4$.

6. Cranidium, dorsal view, ROM 45376, $\times 3$.

7-9. Cranidium, dorsal, frontal, and oblique views, ROM 45330, $\times 4$.

10,11. Pygidium, lateral and dorsal views, ROM 45342, $\times 2$.

12. Hypostome, latex impression, ventral view, $\mathrm{ROM} 45375, \times 6$.

13,14. Pygidium, lateral and dorsal views, ROM 45360, $\times 2$.

15. Pygidium, lateral view enlarged to show prosopon, ROM $45360, \times 4$. 

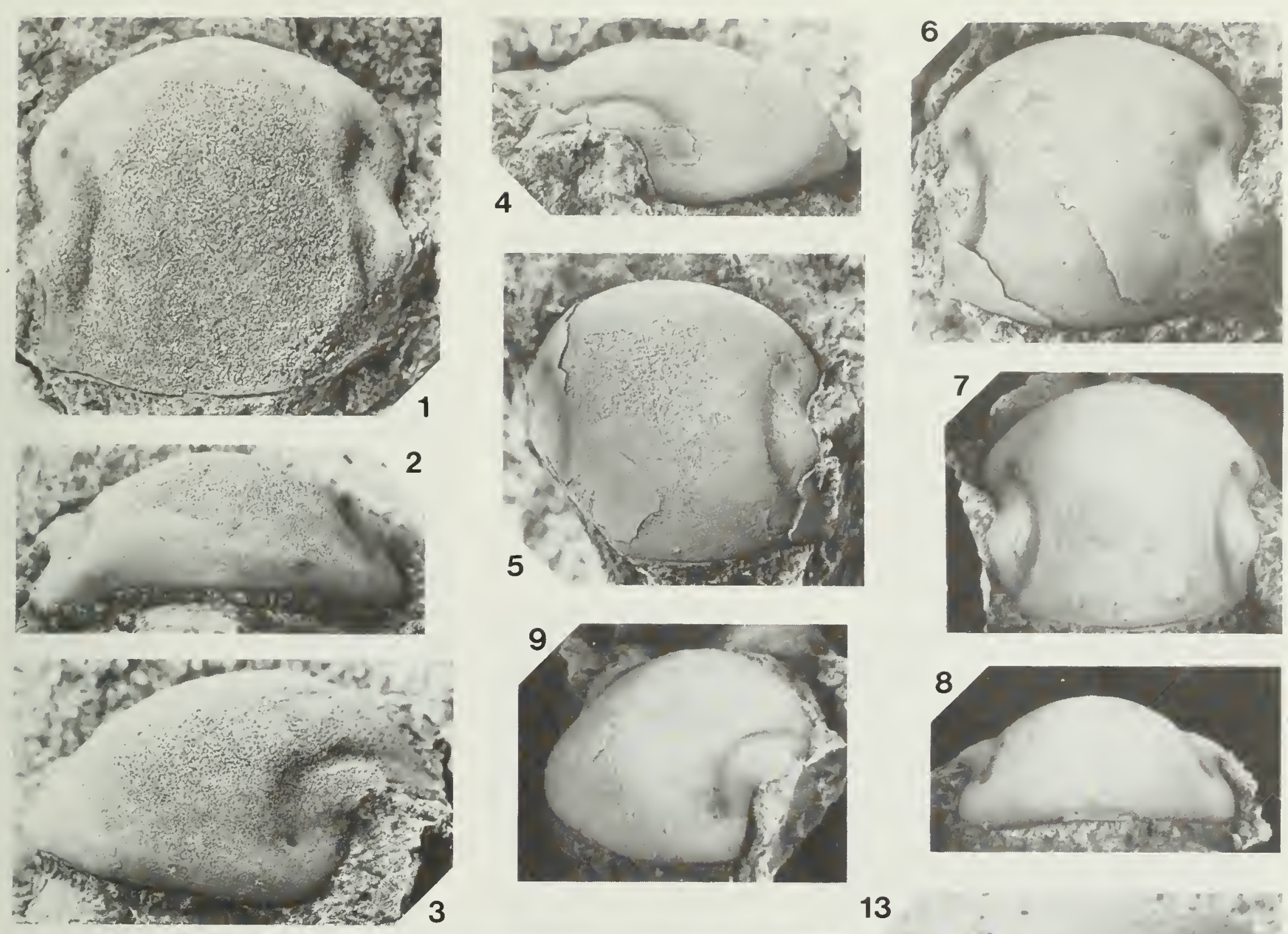

13

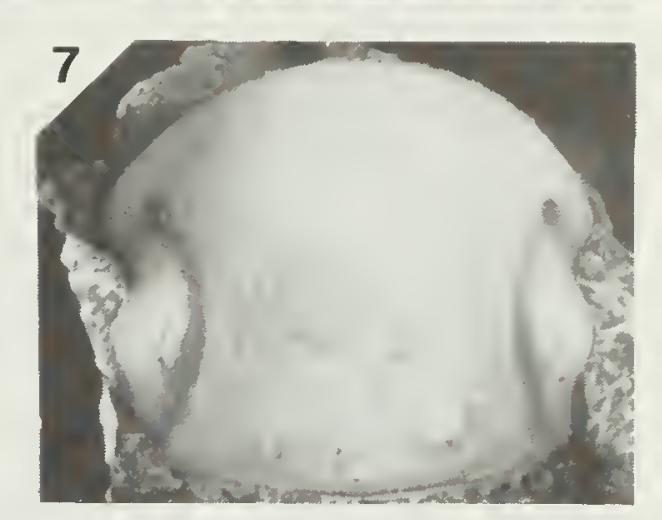

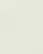

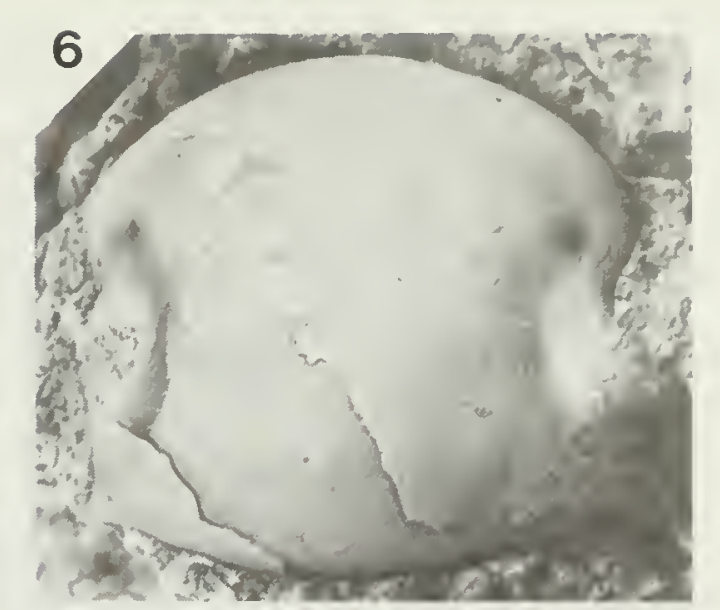

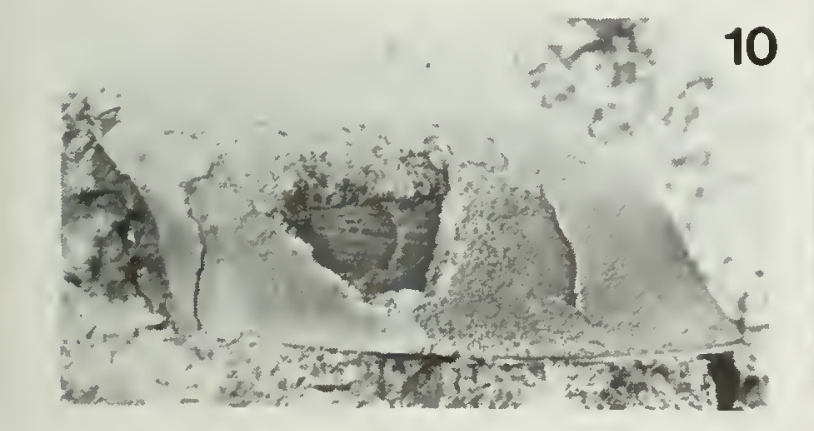
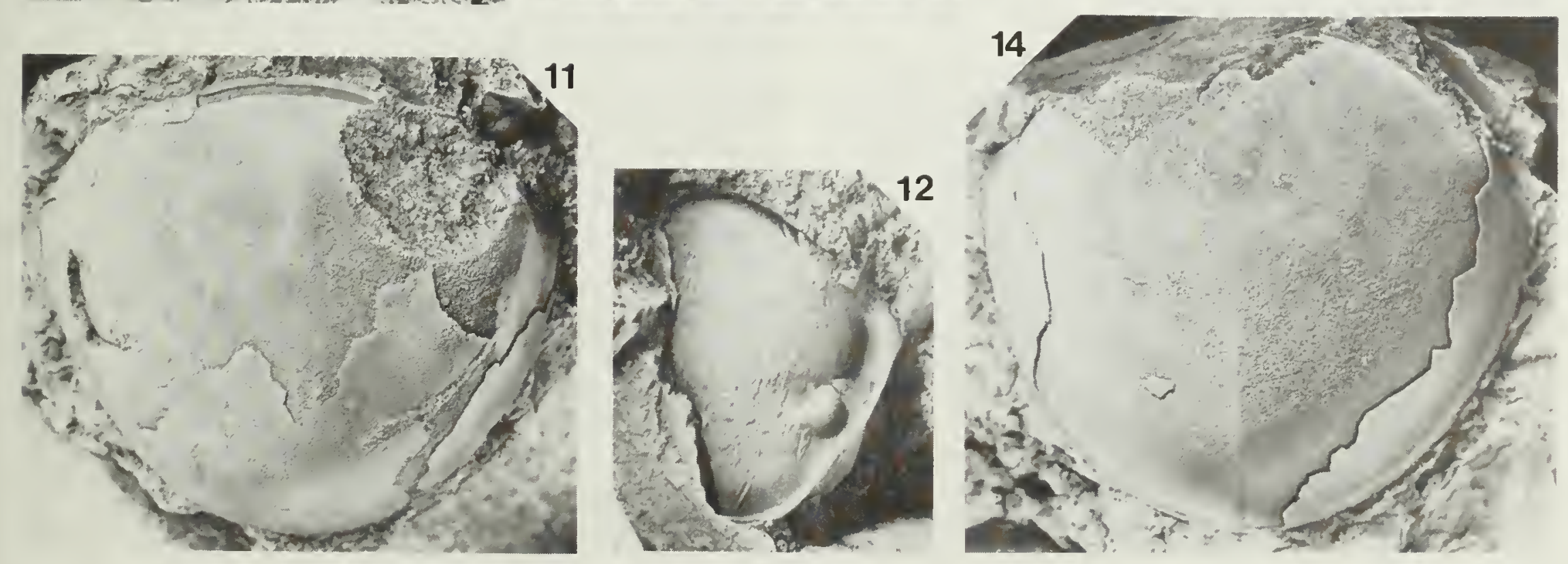
Plate 2, figs. 1-12.

Kosovopeltis borealis (Poulsen), locality AA 2-4.5, Road River Formation, Prongs Creek, Yukon Territory, Canada.

1,2. Complete specimen, dorsal views, $\mathrm{ROM} 42143, \times 4$.

3. Librigena, ventral view, ROM 42144, $\times 3$.

4. Rostral plate, ventral view, ROM 42145, $\times 4$.

5,6. Cranidium, dorsal and oblique views, ROM 42146, $\times 4$.

7. Hypostome, ventral view, ROM 42147, $\times 9$.

8. Hypostome, ventral view, ROM 42148, $\times 9$.

9. Cranidium, dorsal view, ROM 42149, $\times 9$.

10. Pygidium, latex impression, dorsal view, ROM 42150, $\times 9$.

11. Pygidium, dorsal view, ROM 42151, $\times 1.4$.

12. Pygidium, dorsal view, ROM 42152, $\times 1.4$. 

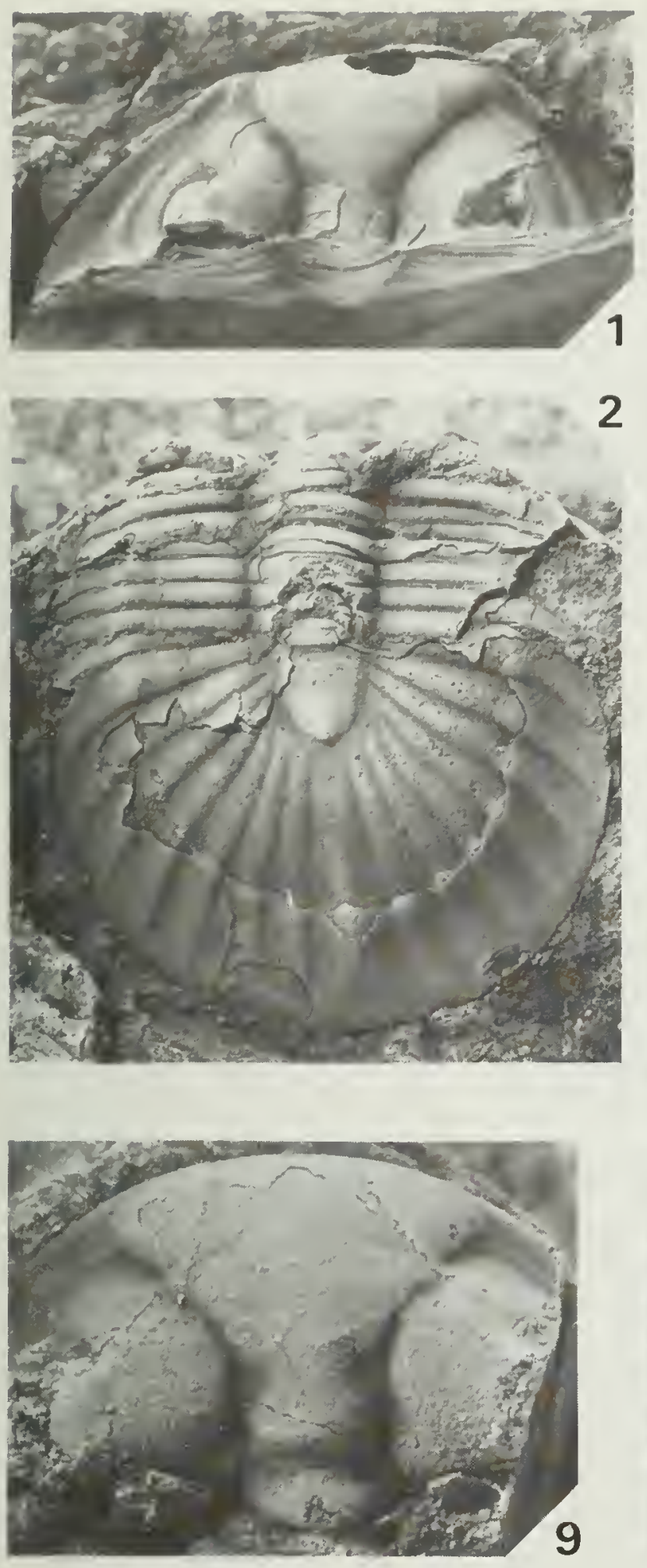
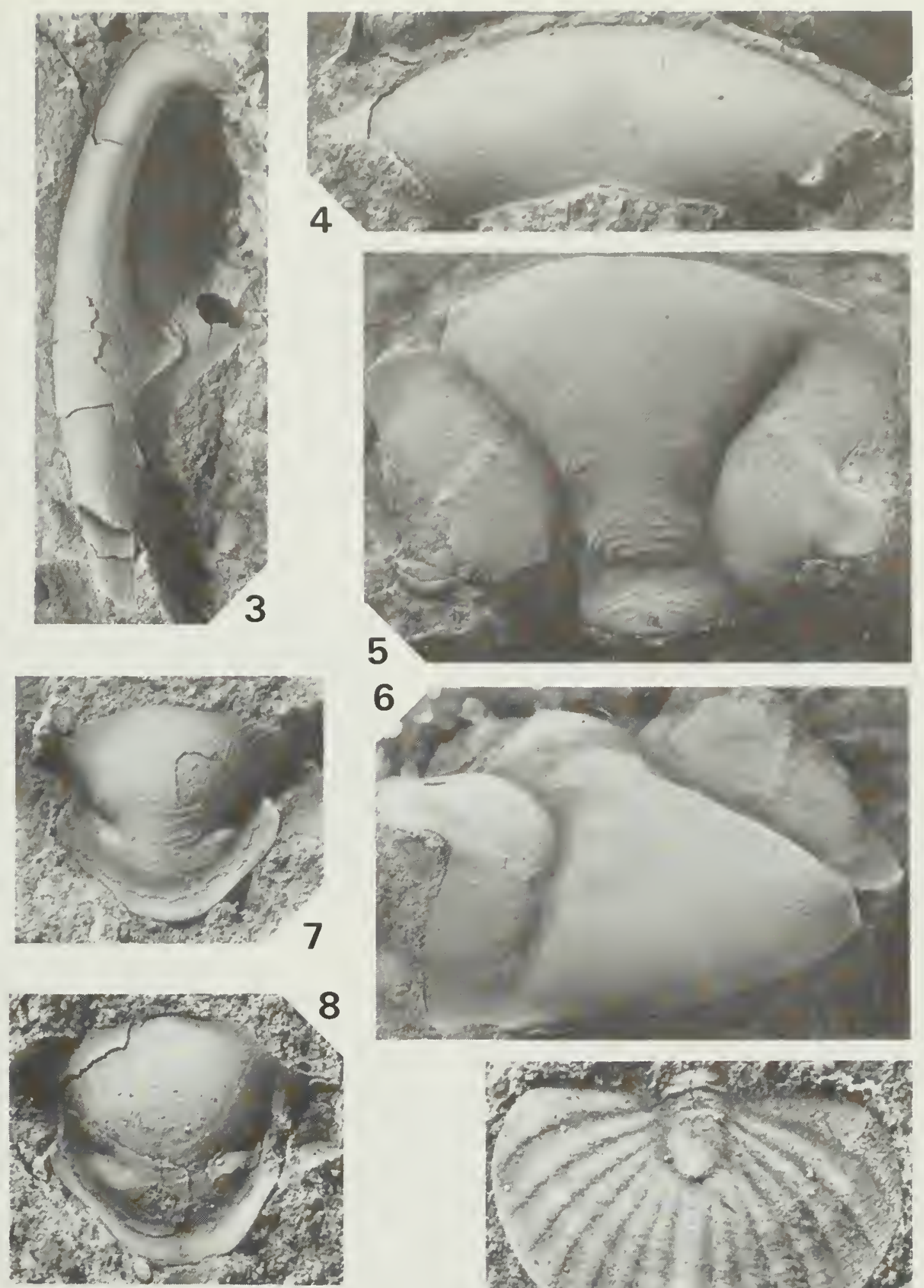

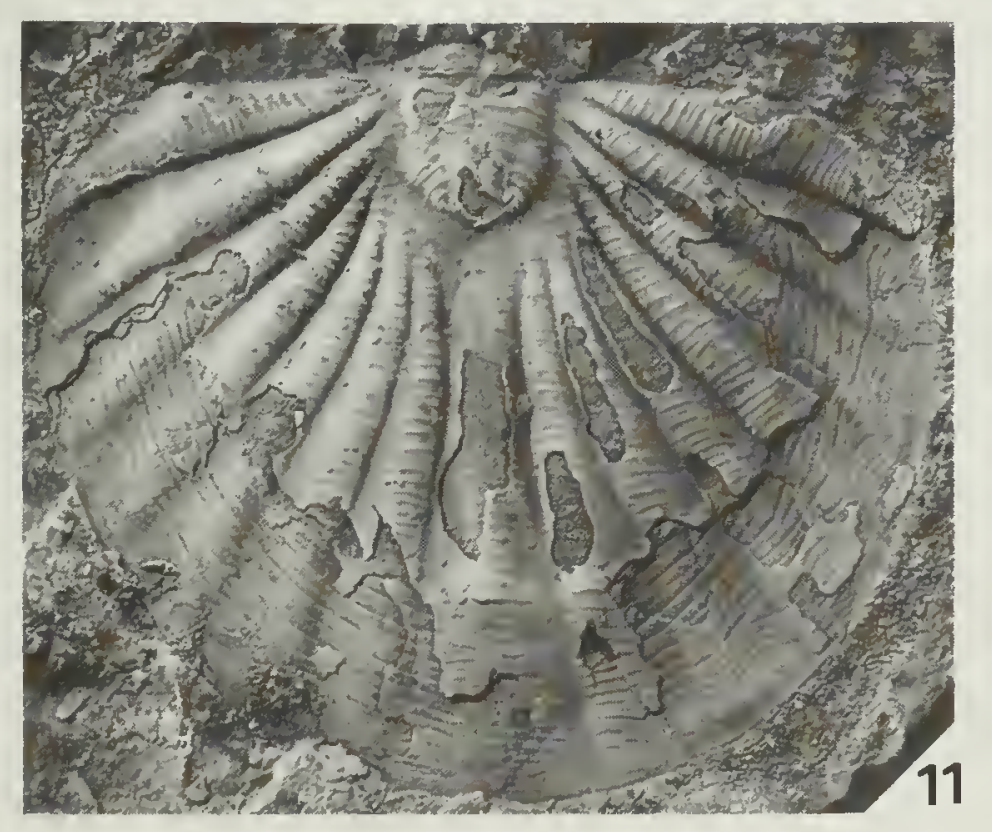

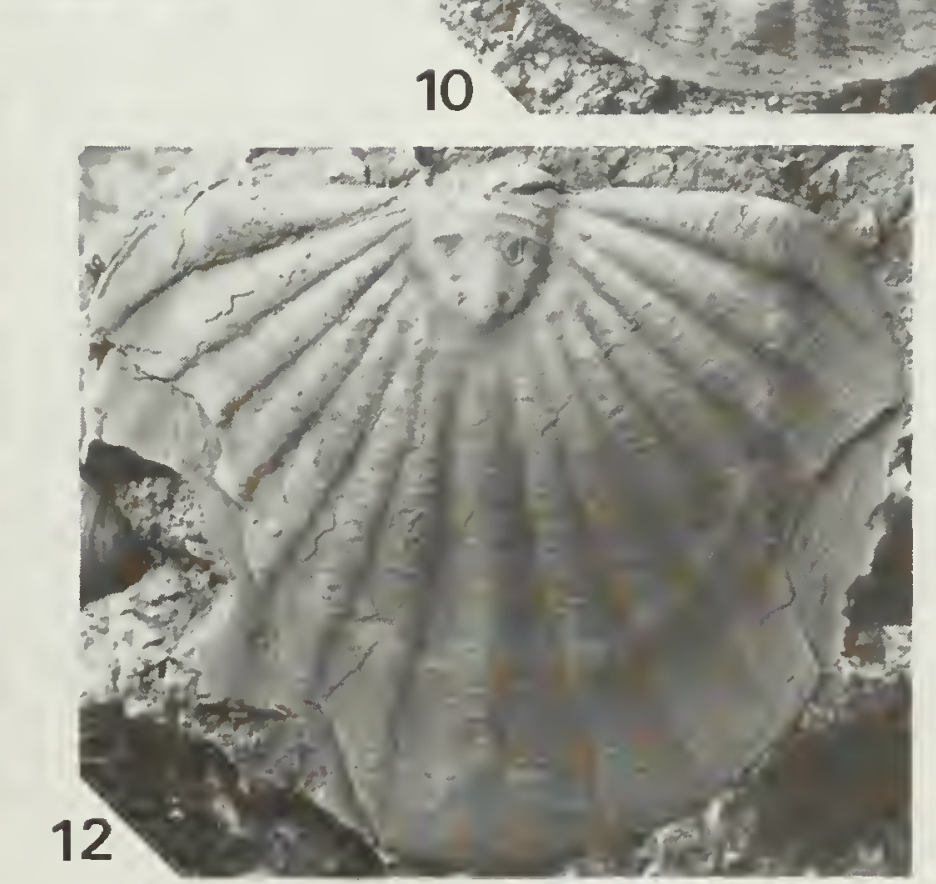


Plate 3, figs. 1-10.

Kosovopeltis borealis (Poulsen), locality AA 2-4.5, Road River Formation, Prongs Creek, Yukon Territory, Canada.

1. Cranidium, latex impression, dorsal view, ROM 42153, $\times 4$.

2. Pygidium, latex impression, dorsal view, ROM 42154, $\times 1.7$.

3-5. Cranidium with rostral plate, dorsal, anterior, and ventral views, ROM 42155, $\times 2$.

6. Librigena, dorsal view, ROM 42156, $\times 3$.

7. Pygidium, latex impression, ventral view, ROM 42157a, $\times 1.7$.

8. Slab crowded with pygidia, ROM $42157, \times 1$.

9. Librigena, dorsal view, ROM 42158, $\times 4$.

10. Cranidium, latex impression, dorsal view, ROM 42159, $\times 4$. 

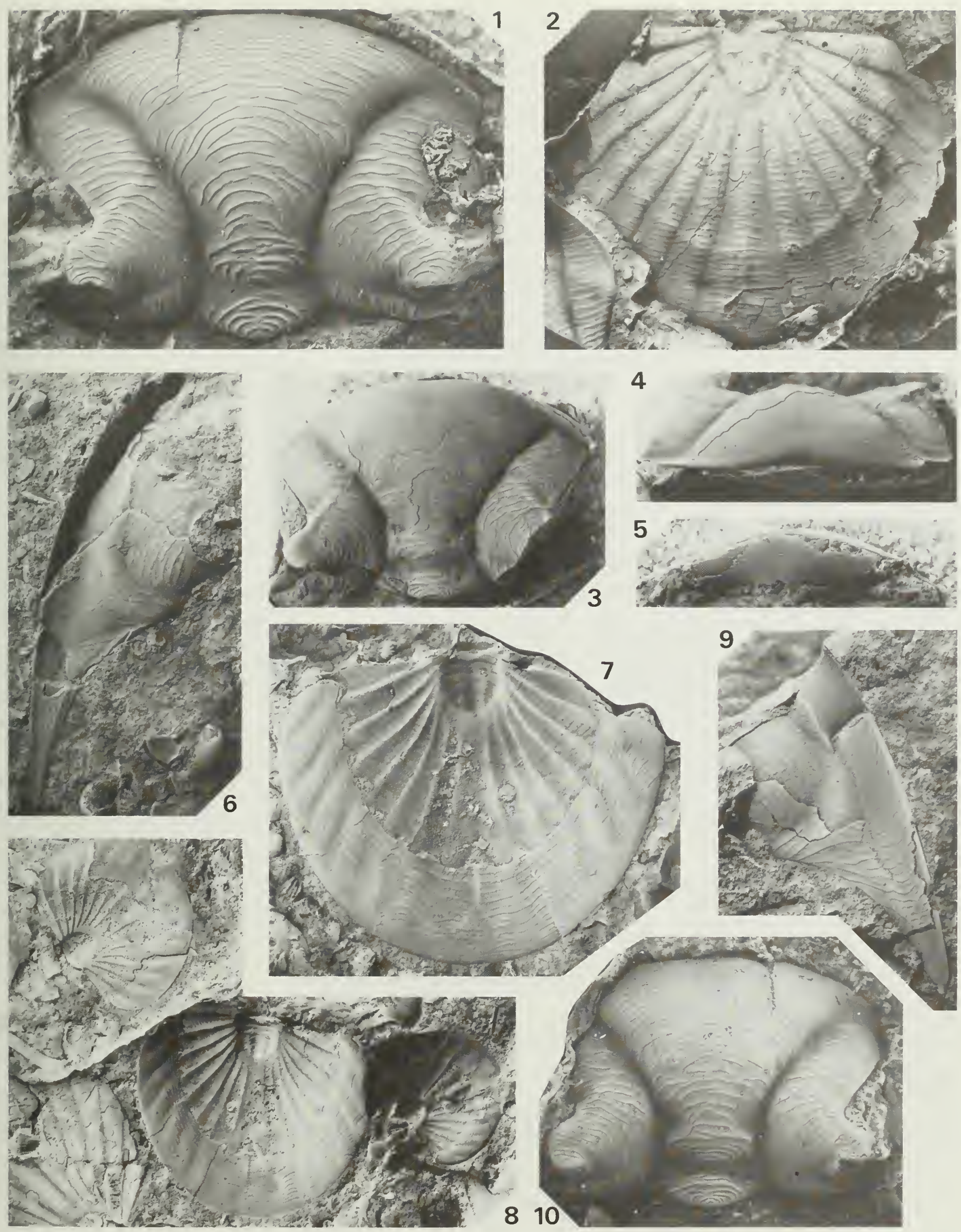
Plate 4, figs. 1-14.

Figs. 1-13. Kosovopeltis borealis (Poulsen), locality AA 2-4.5, Road River Formation, Prongs Creek, Yukon Territory, Canada.

1,2. Protaspis, latex impression, dorsal and oblique views, ROM 42160, $\times 56$.

3,4. Meraspid cranidium, oblique and dorsal views, ROM 42161, $\times 24$.

5. Transitory pygidium with one protothoracic segment attached, dorsal view, ROM 42162, $\times 12$.

6,7. Transitory pygidium with two protothoracic segments attached, latex impression, dorsal and oblique views, ROM 42163, × 12 .

8,9 . Internal mould of lens surface of holaspid eye, ROM 42164, $\times 100$ and $\times 500$.

10,11. Transitory pygidium, latex impression, oblique and dorsal views, $\operatorname{ROM} 42165, \times 50$.

12,13. Smallest transitory pygidium, ROM 42166, $\times 56$ and $\times 92$.

Fig. 14. Otarion (Songkania) socialis (Pouisen), locality AA 2-4.5, Road River Formation, Prongs Creek, Yukon Territory, Canada, hypostome, ventral view, ROM 42204, × 24 . 


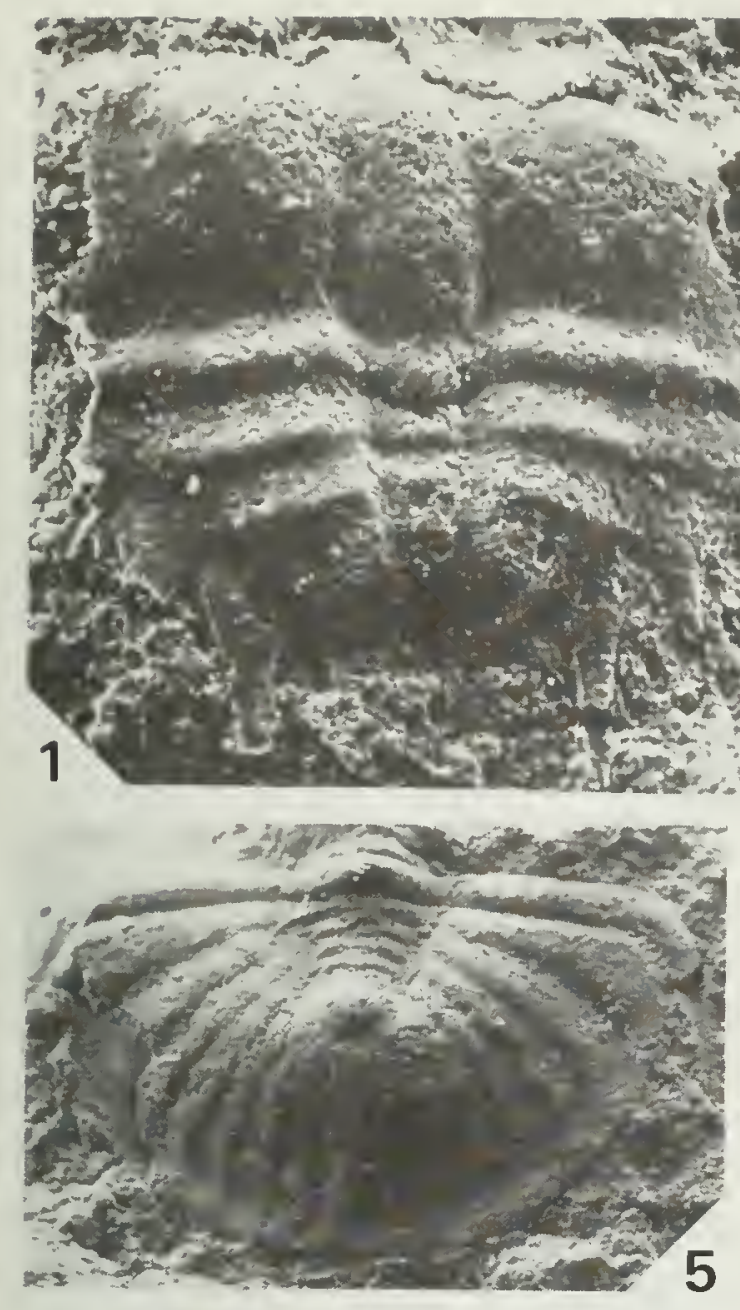

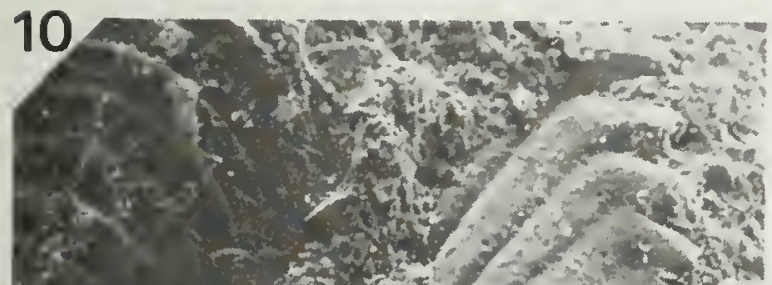
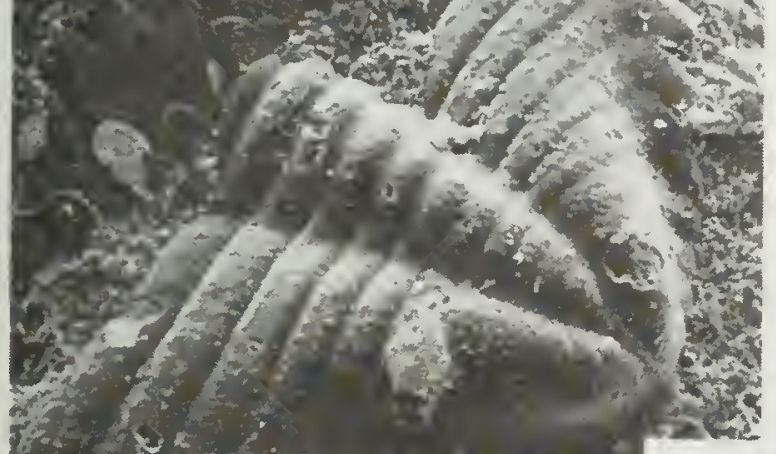
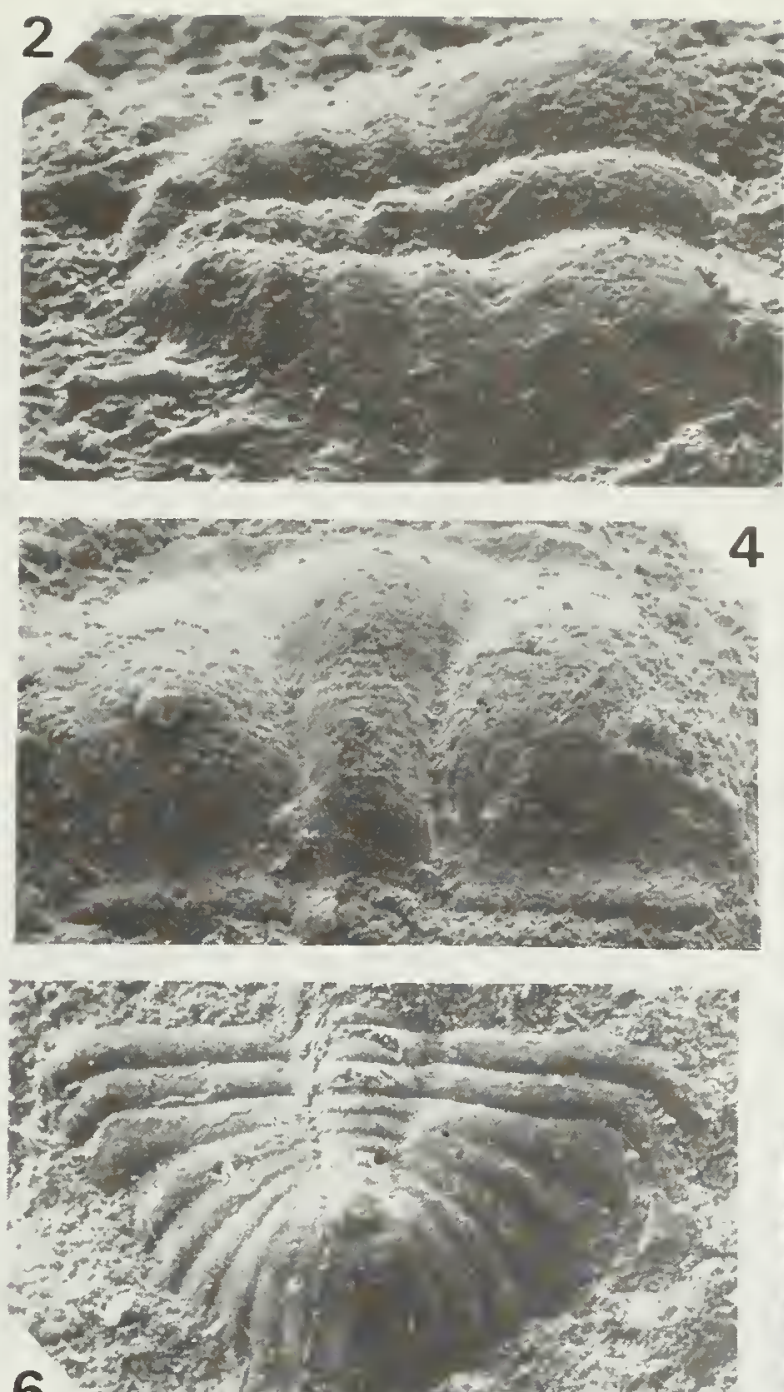

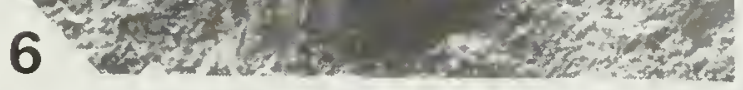

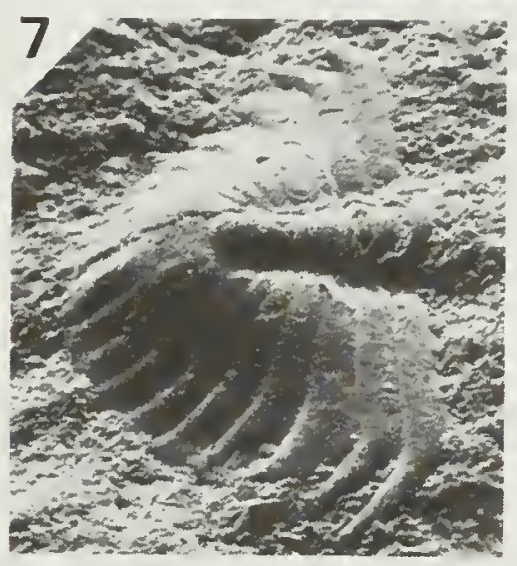

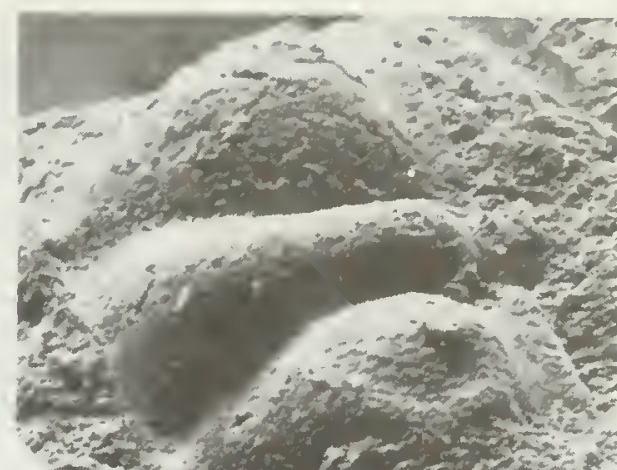

\section{7}

$4+x^{2}+3$

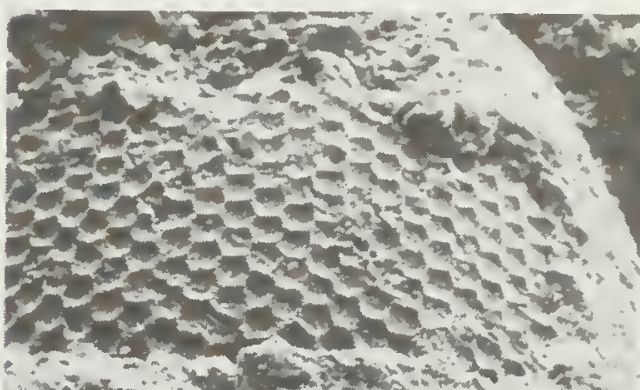

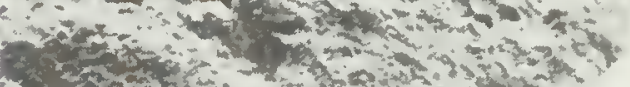

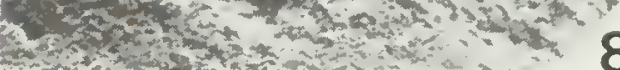

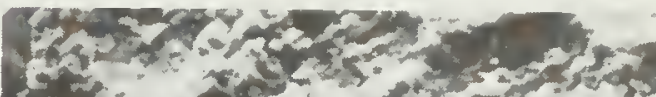

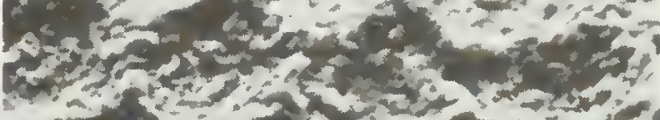
$5+12=0$

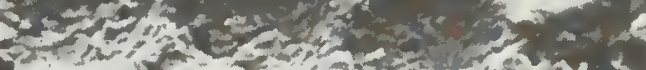

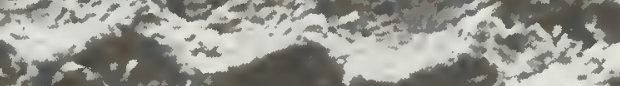

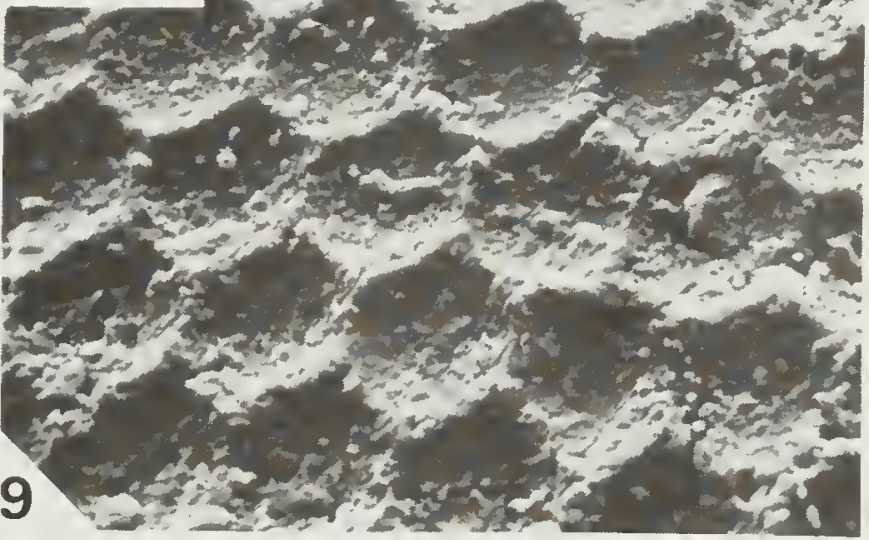

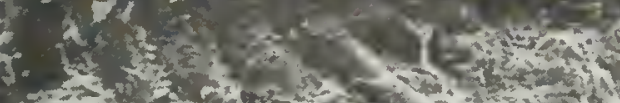

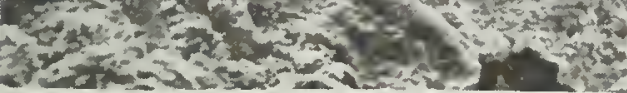

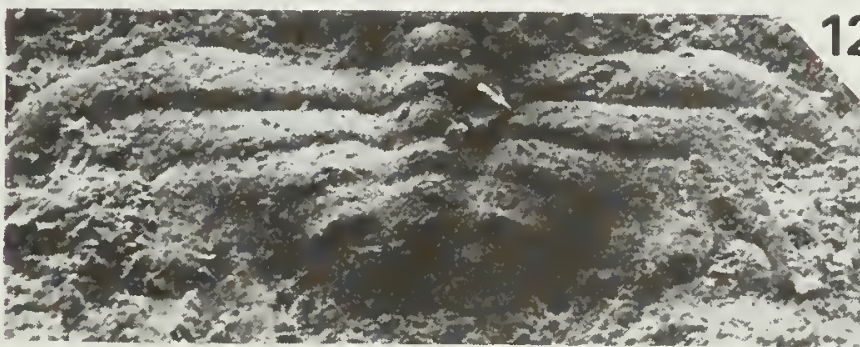

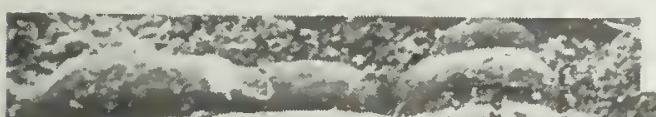

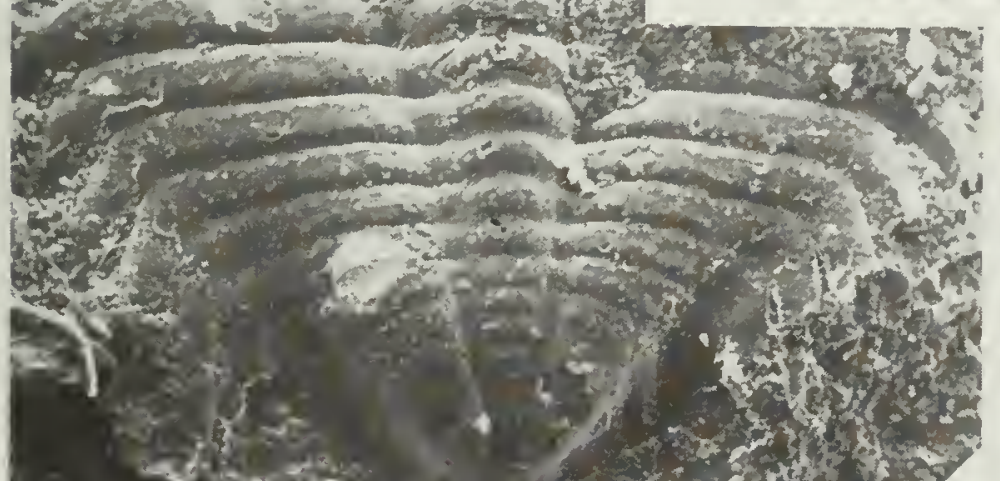

ars

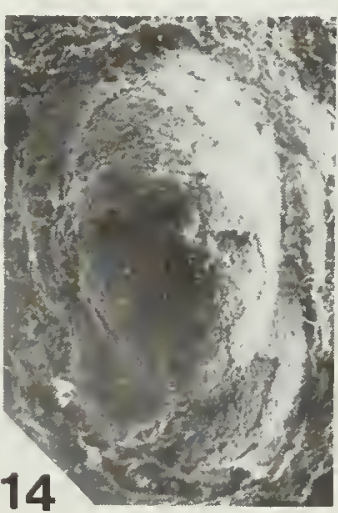

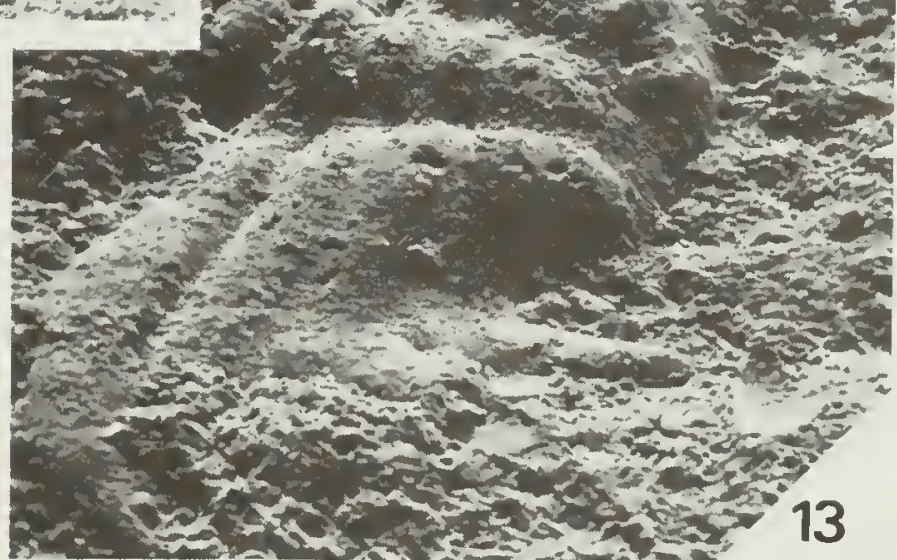


Plate 5, figs. 1-16.

All specimens are from locality BB 131, unnamed carbonates, Illtyd Range, Yukon Territory, Canada.

Figs. 1-11. Stenopareia illtyd sp. nov.

1,2. Cranidium, dorsal and oblique views, ROM 42167, $\times 3$.

3,4. Holotype cranidium, dorsal and anterior views, ROM 42168, $\times 3$.

5,6. Cranidium, dorsal and anterior views, ROM 42169, $\times 3$.

7. Pygidium, dorsal view, ROM 42170, $\times 9$.

8,9. Pygidium, dorsal and lateral views, ROM 42171, $\times 4$.

10,11. Pygidium, dorsal and oblique views, ROM 42172, $\times 5$.

Fig. 12. Indeterminate illaenid, cephalon, dorsal view, ROM 42173, × 3 .

Figs. 13,14. Indeterminate bumastine, cranidium, dorsal and anterior views, ROM 42174, $\times 9$.

Figs. 15,16. Cheinums sp., cranidium, lateral and dorsal views, ROM 42175, $\times 5$. 

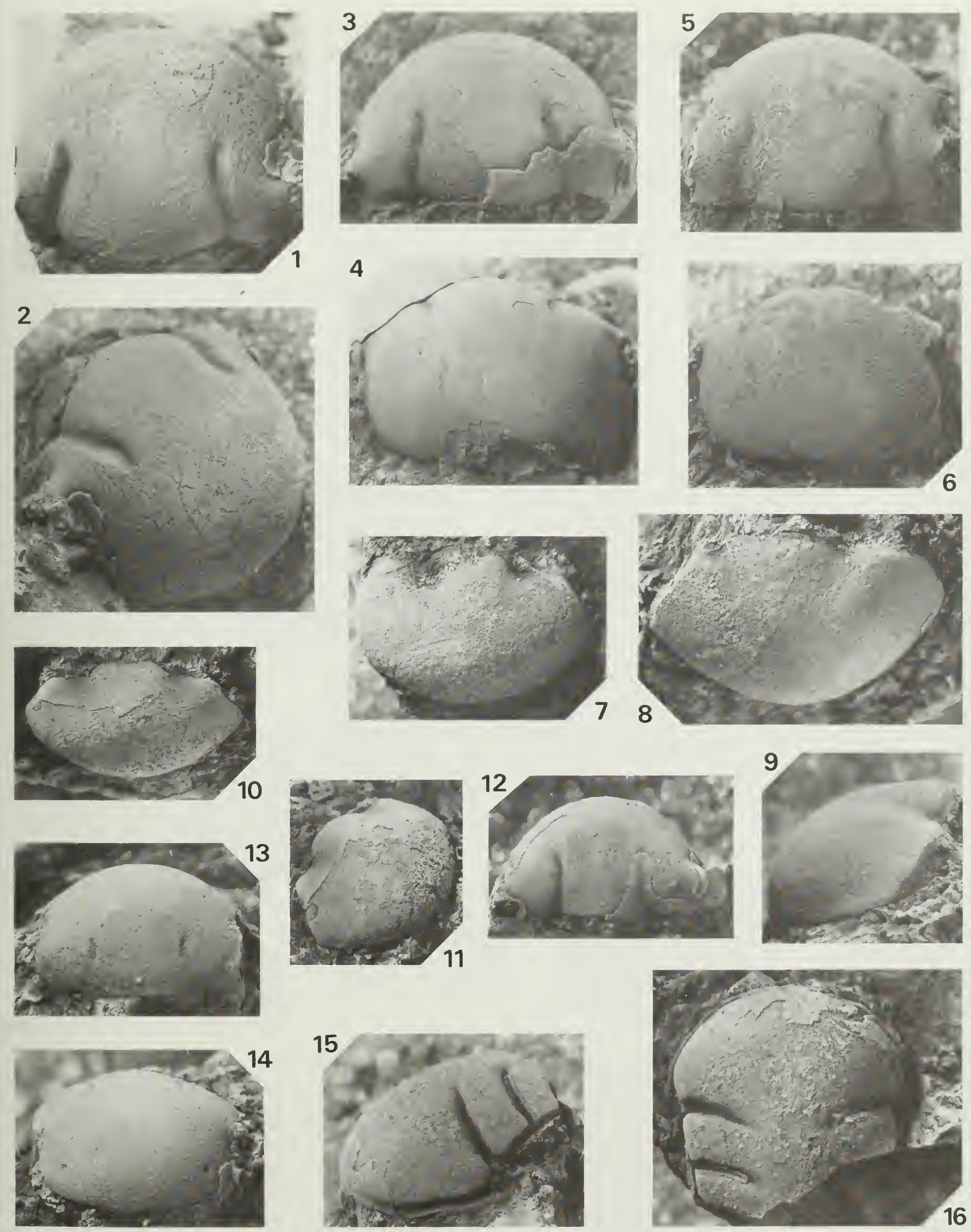
Plate 6, figs. 1-24.

Figs. 1-14. Hedstroemia kutchini sp. nov., locality AA 95, Road River Formation, Prongs Creek, Yukon Territory, Canada.

1,2. Cranidium, dorsal and oblique views, ROM 45371, $\times 5$.

3,4. Holotype cranidium, dorsal and oblique views, ROM 45347, $\times 6$.

5. Cranidium, dorsal view, ROM 45348, $\times 6$.

6,7. Pygidium, dorsal and lateral views, ROM 45334, $\times 4$.

8. Pygidium, dorsal view, ROM 45335, $\times 4$.

9,10. Pygidium, dorsal and lateral views, ROM 45328a, $\times 4$.

11. Librigena, dorsal view, ROM 45372, $\times 6$.

12. Librigena, latex impression, dorsal view, ROM 45358, $\times 5$.

13. Hypostome, ventral view, $\mathrm{ROM} 45329, \times 8$.

14. Hypostome, ventral view, ROM $45370, \times 8$.

Fig. 15. Indeterminate proetid A, locality AA 95, Road River Formation, Prongs Creek, Yukon Territory, Canada, hypostome, ventral view, ROM 45338b, $\times 8$.

Figs. 16-24. Hedstroemia sourdoughi sp. nov., locality AA 95, Road River Formation, Prongs Creek, Yukon Territory, Canada.

16. Pygidium, dorsal view, $\mathrm{ROM} 45333, \times 4$.

17-19. Pygidium, posterior, lateral, and dorsal views, ROM 45331, $\times 6$.

20. Pygidium, dorsal view, ROM 45323, $\times 5$.

21. Cranidium, latex impression, dorsal view, $\mathrm{ROM} 45357, \times 4$.

22,23 . Holotype cranidium, dorsal and oblique views, ROM 45332, $\times 4$.

24. Cranidium, dorsal view, ROM 45326, $\times 6$. 

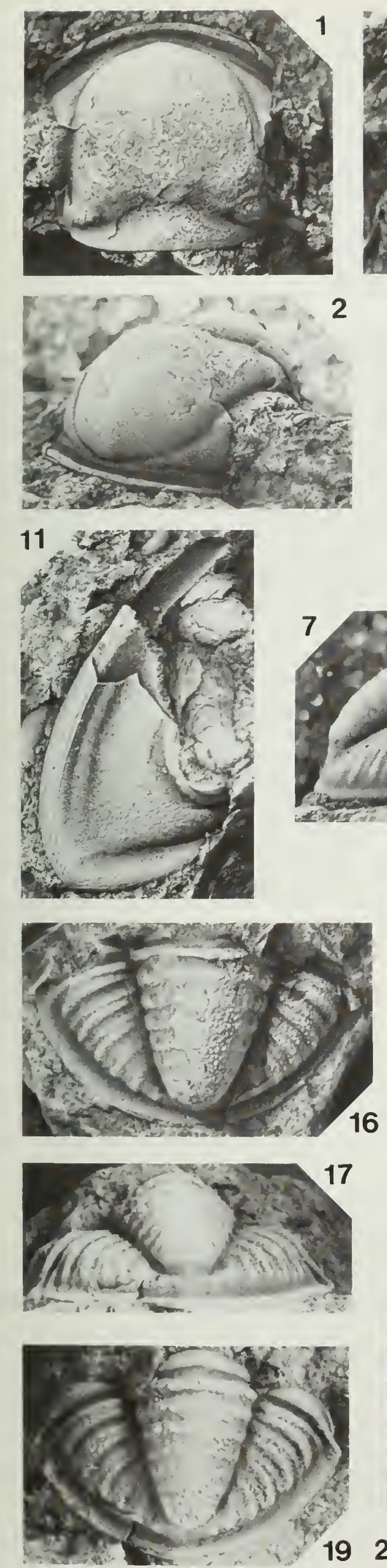
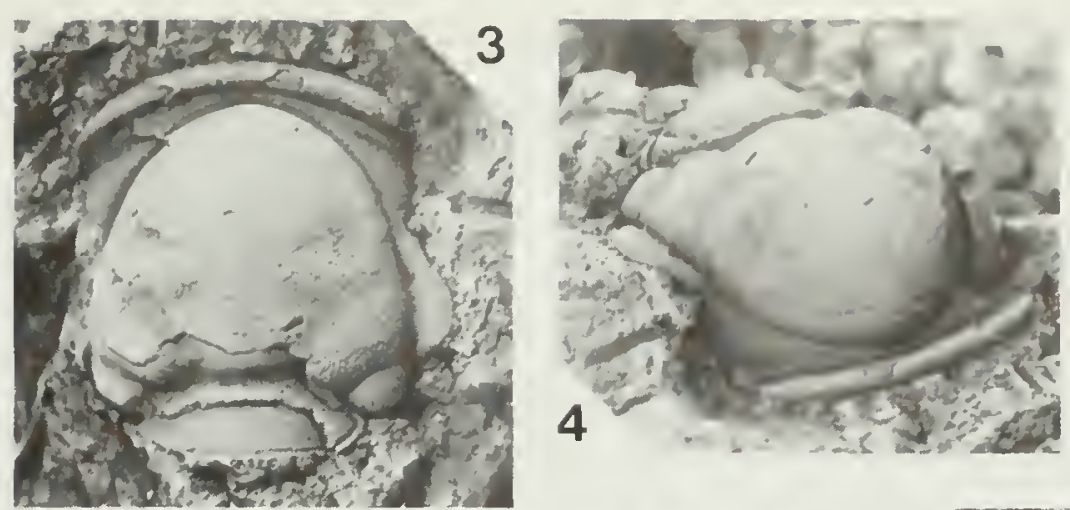
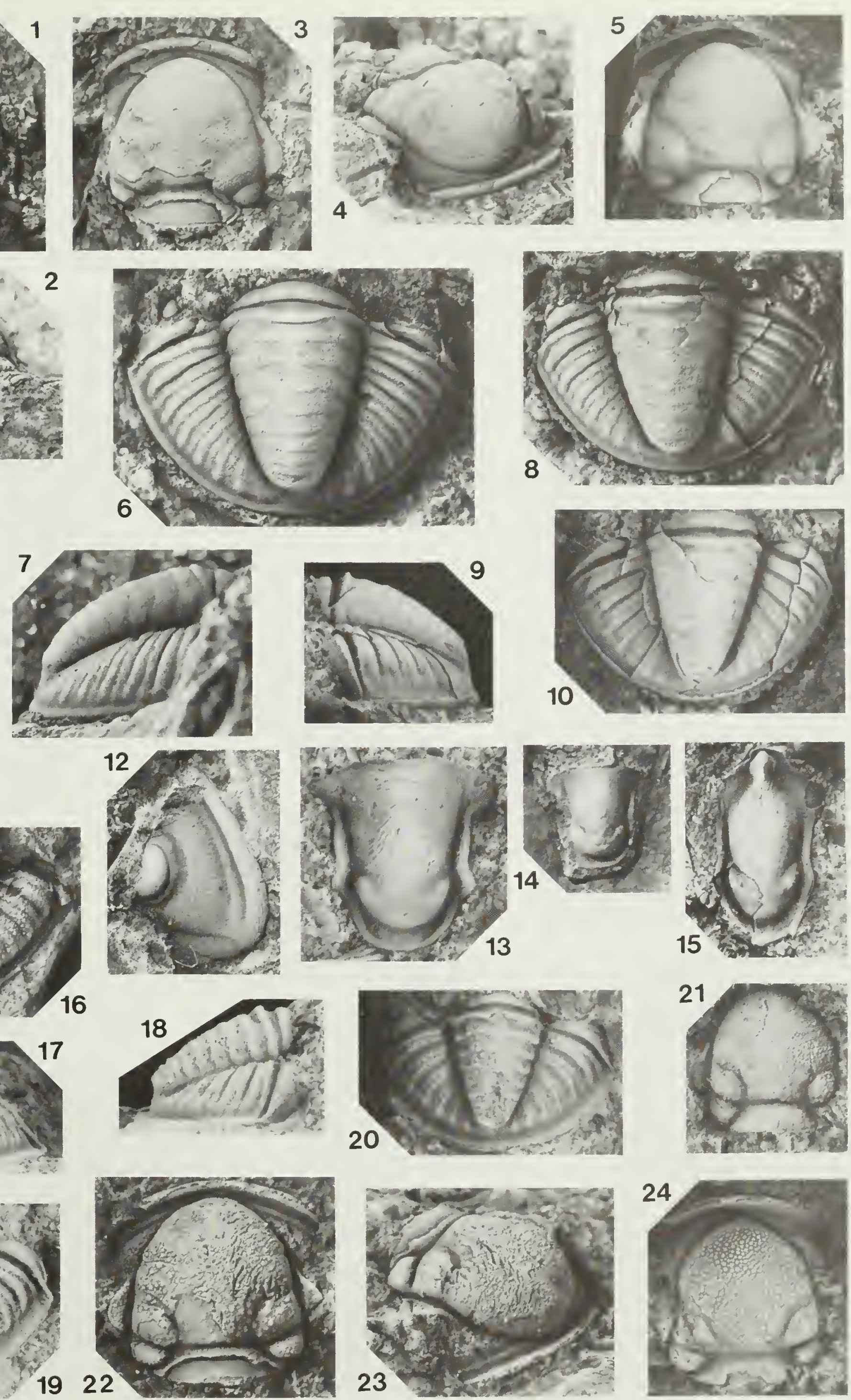
Plate 7, figs. 1-20.

Figs. 1-15. Prantlia vagrans sp. nov., locality AA 95, Road River Formation, Prongs Creek, Yukon Territory, Canada.

1. Cranidium, dorsal view, $\operatorname{ROM} 45339, \times 4$.

2. Cranidium, dorsal view, ROM $45340, \times 4$.

3. Cranidium, latex impression, dorsal view, ROM $45353, \times 6$.

4. Cranidium, dorsal view, ROM 45365, $\times 6$.

5. Librigena, showing narrow doublure, ventral view, ROM 45327, $\times 5$.

6,7. Holotype pygidium, dorsal and oblique views, ROM 45363, $\times 6$.

8. Pygidium, dorsal view, ROM $45337, \times 4$.

9. Pygidium, dorsal view, ROM 45336a, $\times 4$.

10. Meraspid cranidium, latex impression, ROM 45351, $\times 8$.

11. Pygidium, showing narrow doublure, ventral view, ROM 45364, $\times 4$.

12. Pygidium, dorsal view, ROM $45328 \mathrm{~b}, \times 4$.

13. Pygidium, dorsal view, ROM 45341, $\times 5$.

14. Librigena, oblique view, ROM $45338 \mathrm{a}, \times 5$.

15. Librigena, latex impression, oblique view, ROM 45355, $\times 4$.

Figs. 16-20. Indeterminate lichid, locality AA 95, Road River Formation, Prongs Creek, Yukon Territory, Canada.

16. Pygidium, dorsal view, ROM $45361, \times 2$.

17. Pygidium, dorsal view, ROM $45366 \mathrm{~b}, \times 2$.

18. Cranidium, dorsal view, ROM $45349, \times 5$.

19. Cranidium, dorsal view, ROM $47356, \times 5$.

20. Hypostome, latex impression, ventral view, ROM $45354, \times 5$. 

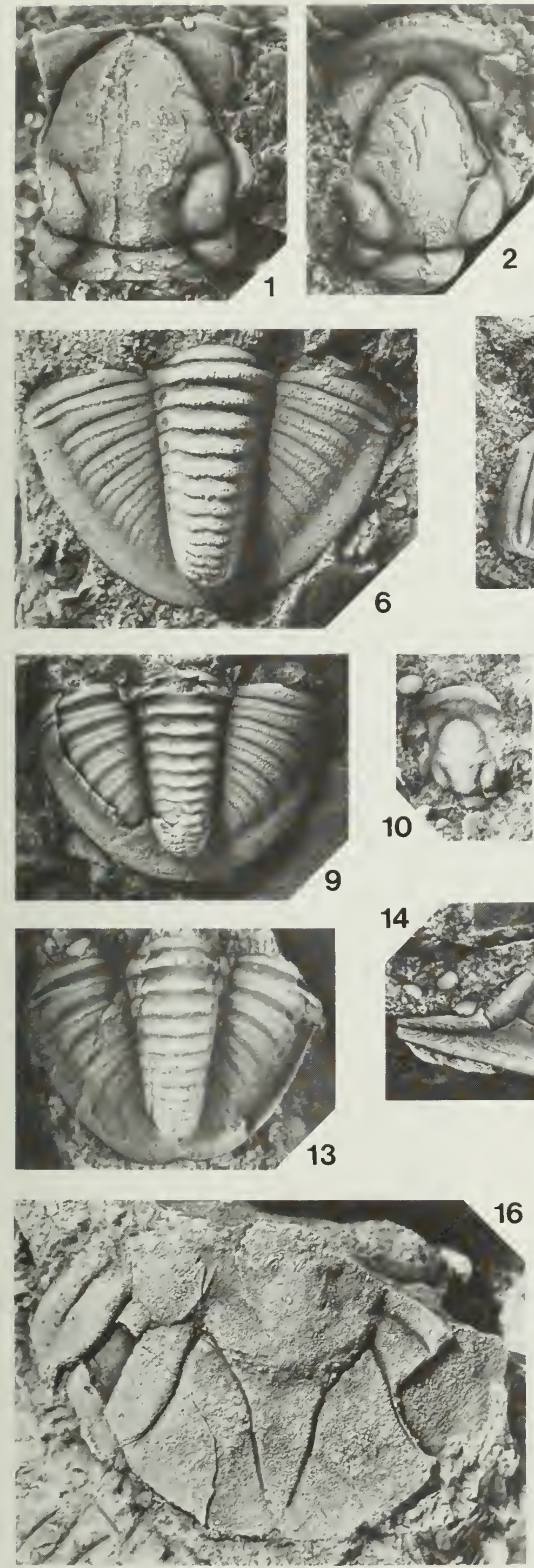
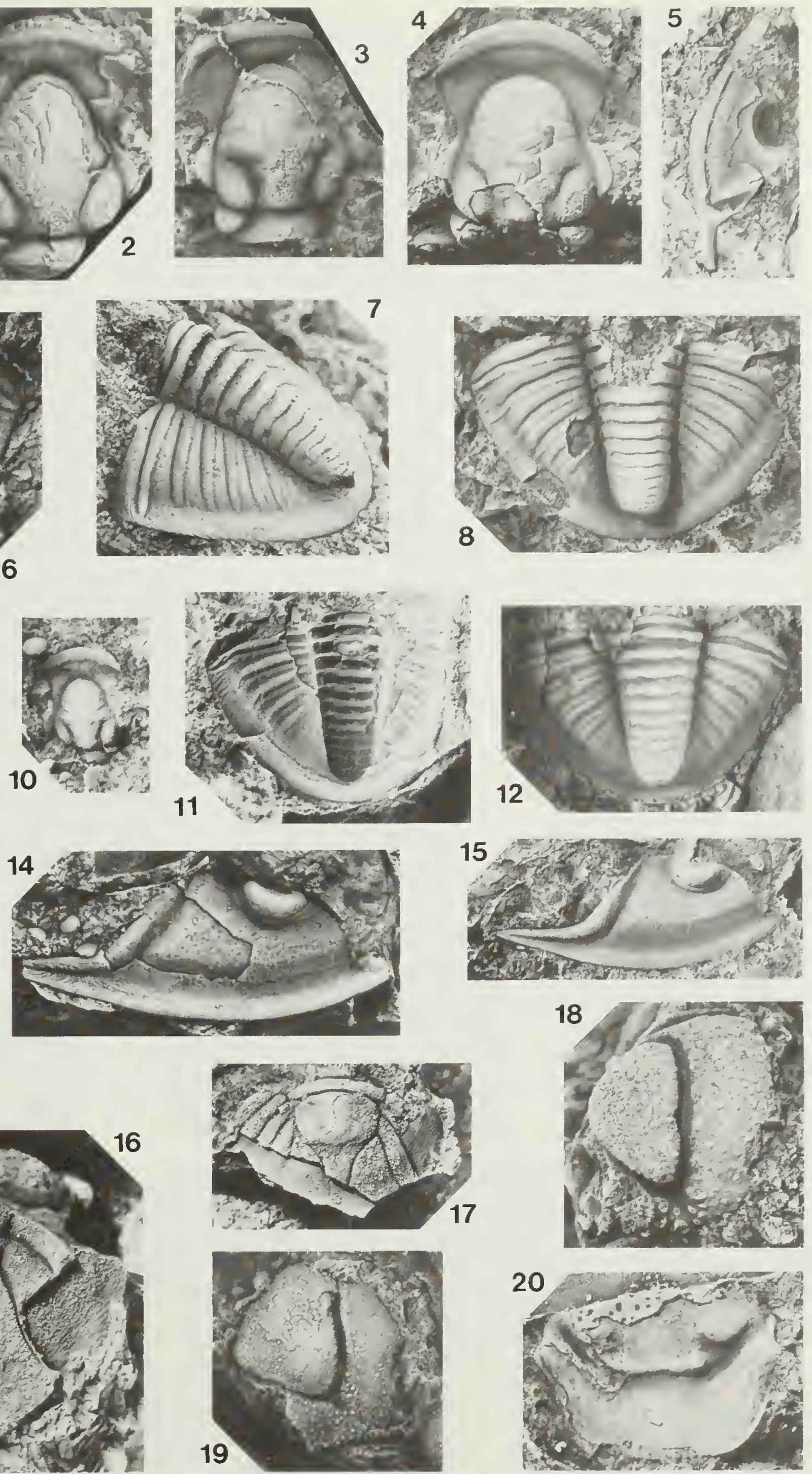
Plate 8, figs. 1-12.

Otarion (Songkania) socialis (Poulsen), locality AA 2-4.5, Road River Formation, Prongs Creek, Yukon Territory, Canada.

1,2. Complete specimen, dorsal and oblique views, $\mathrm{ROM} 42176, \times 7.5$.

3,4. Cranidium, dorsal and anterior views, ROM 42177, $\times 9$.

5. Complete specimen lacking axial spine on sixth segment, dorsal view, ROM $42178, \times 7.5$.

6,7. Complete specimen with axial spine on sixth segment, dorsal and oblique views, ROM 42179, $\times 6$.

8. Cephalon and thorax with axial spine on sixth segment, oblique view, ROM $42180, \times 5$.

9. Librigena, oblique view, ROM 42181, $\times 9$.

10,11. Complete specimen, dorsal and oblique views, ROM 42182, × 7.5.

12. Librigena, oblique view, $\operatorname{ROM} 42183, \times 9$. 


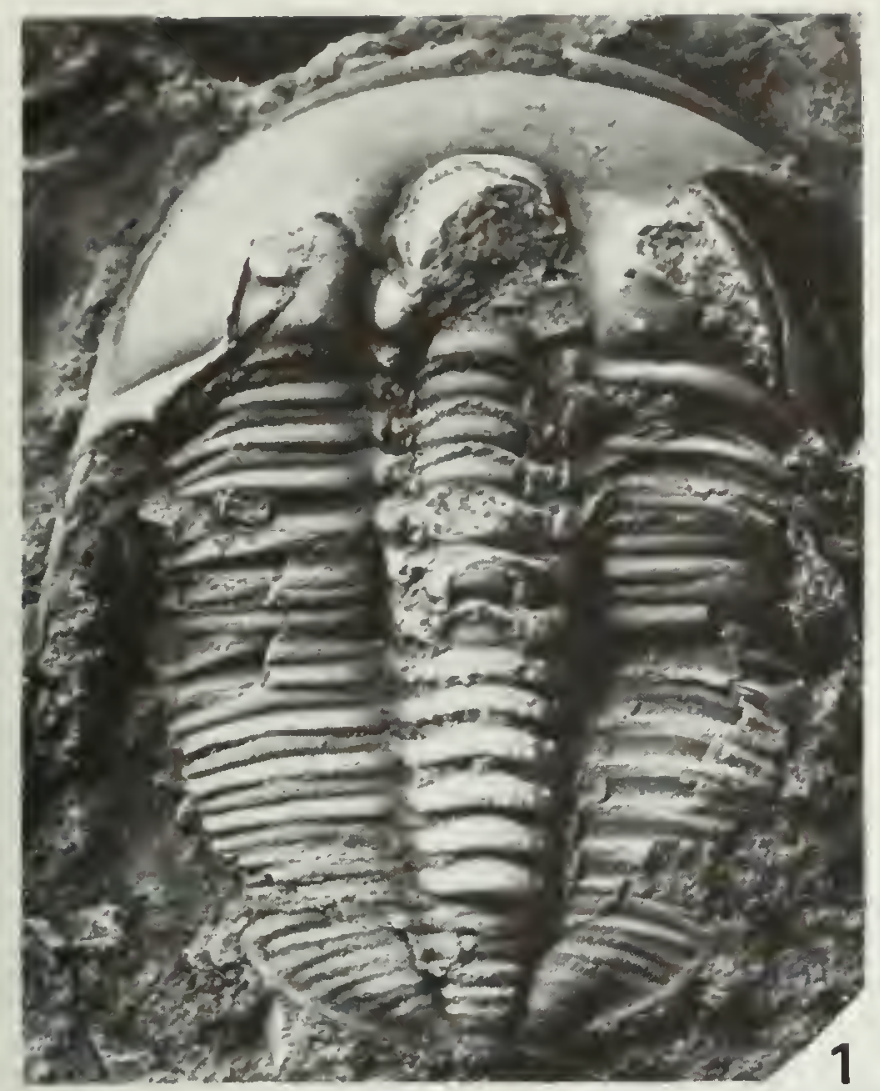

\section{2}

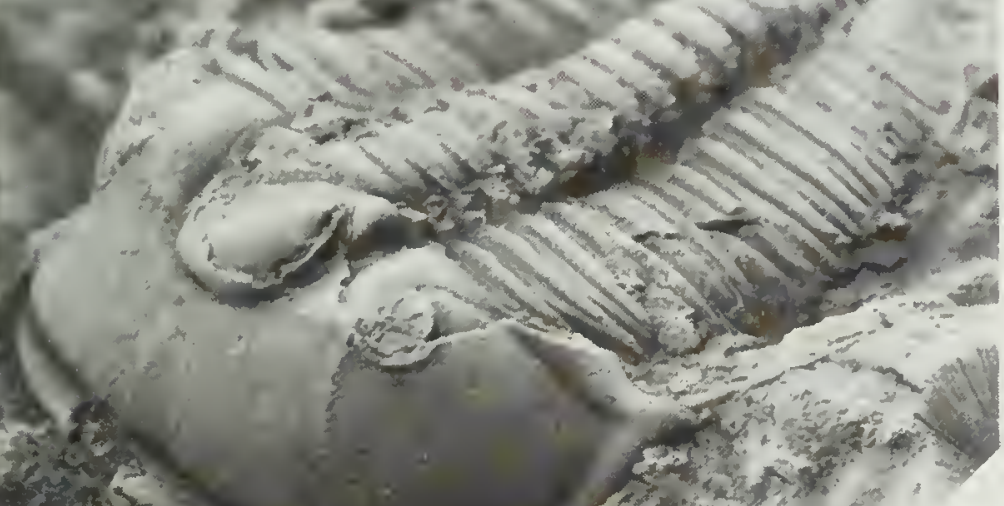

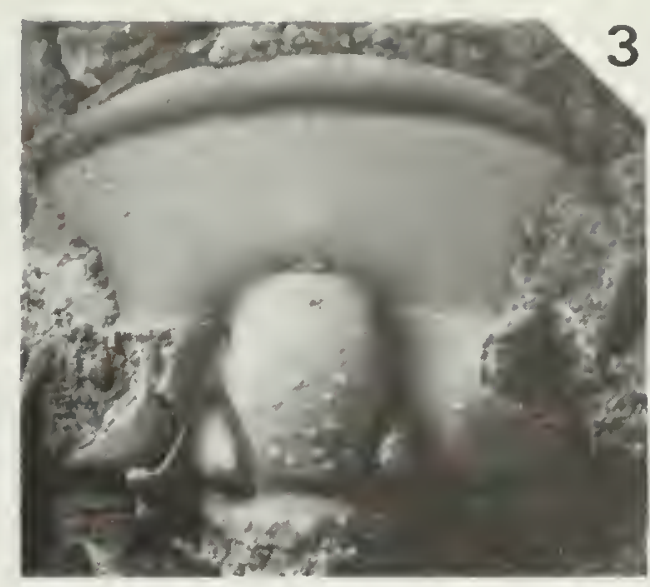

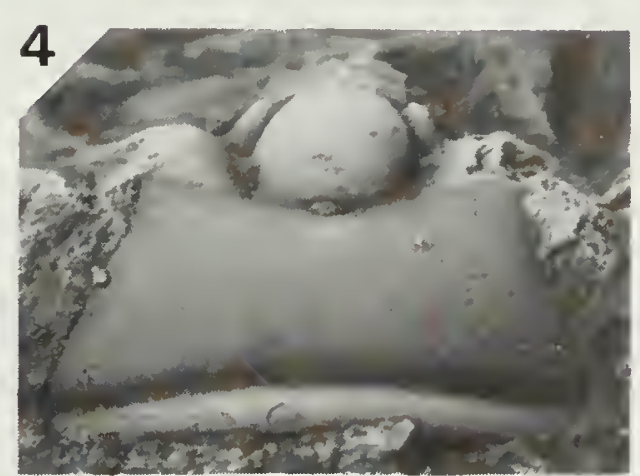

5
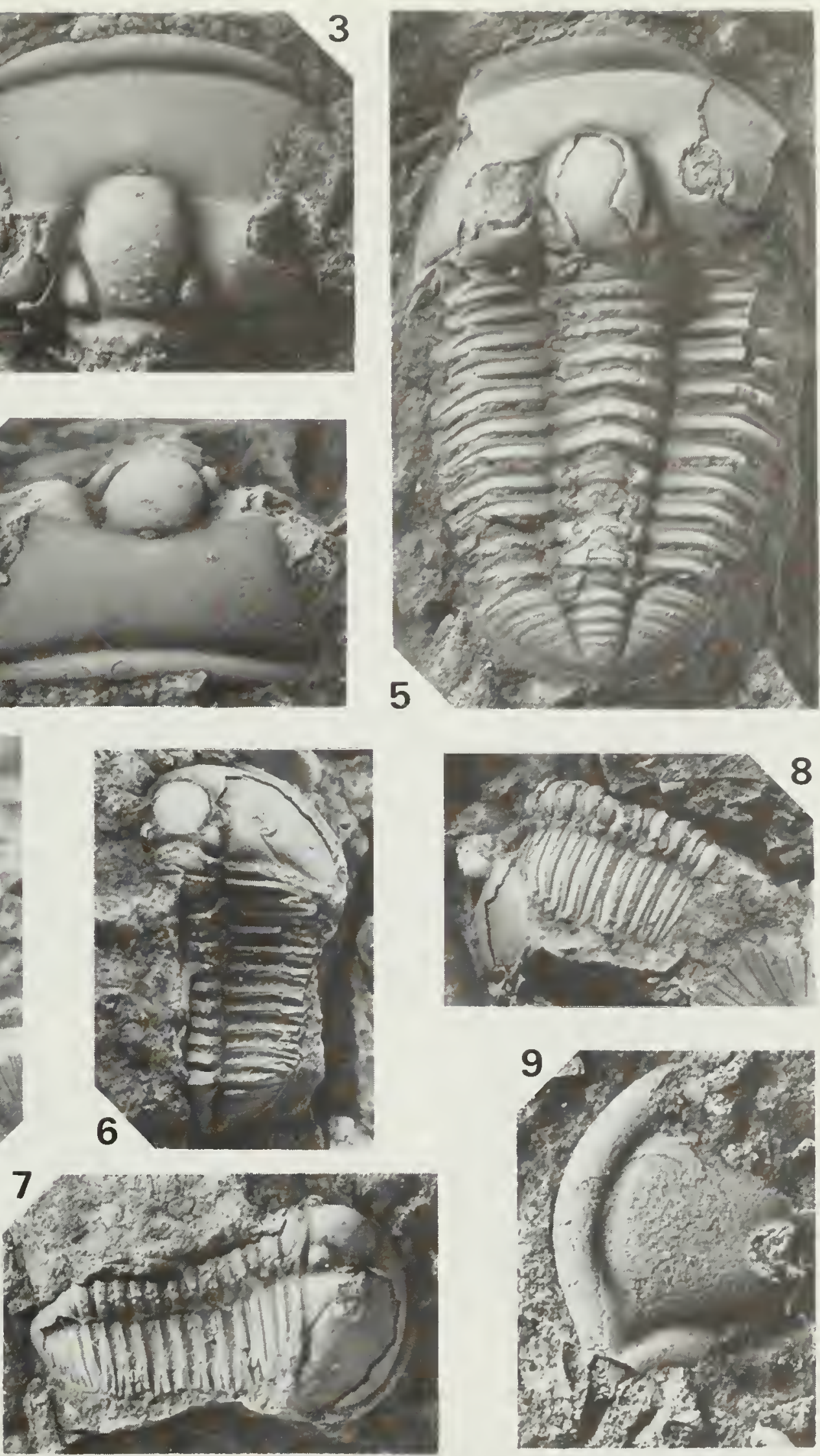

11
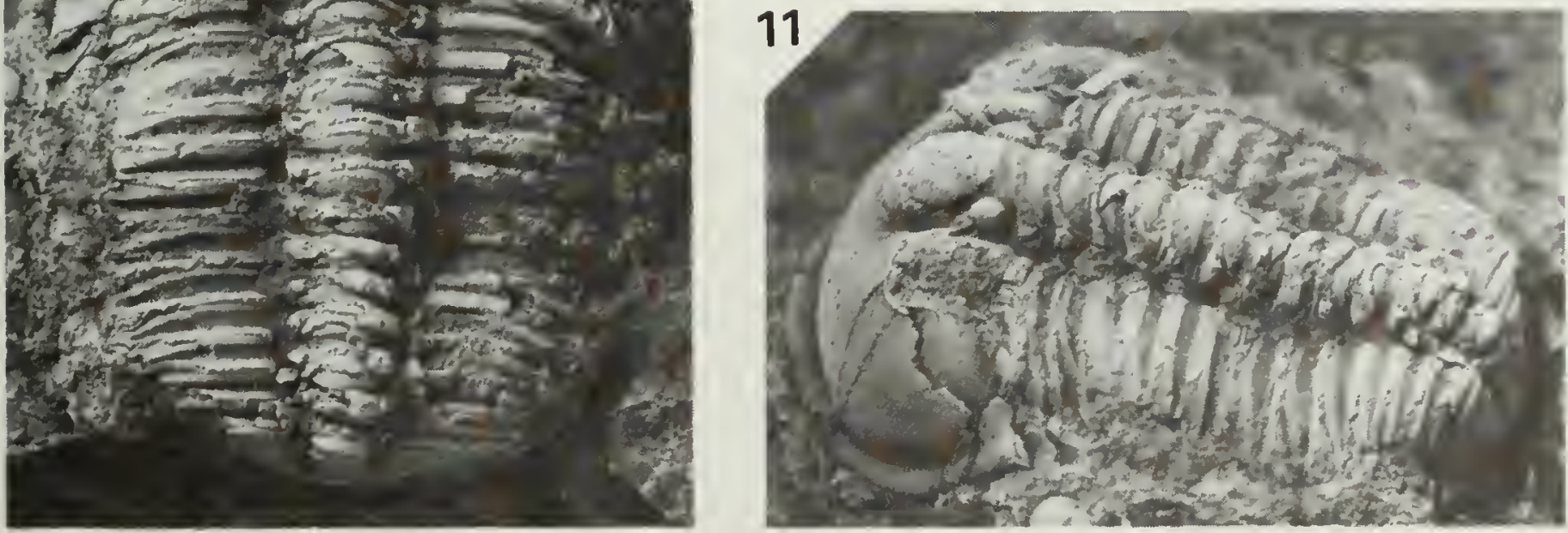
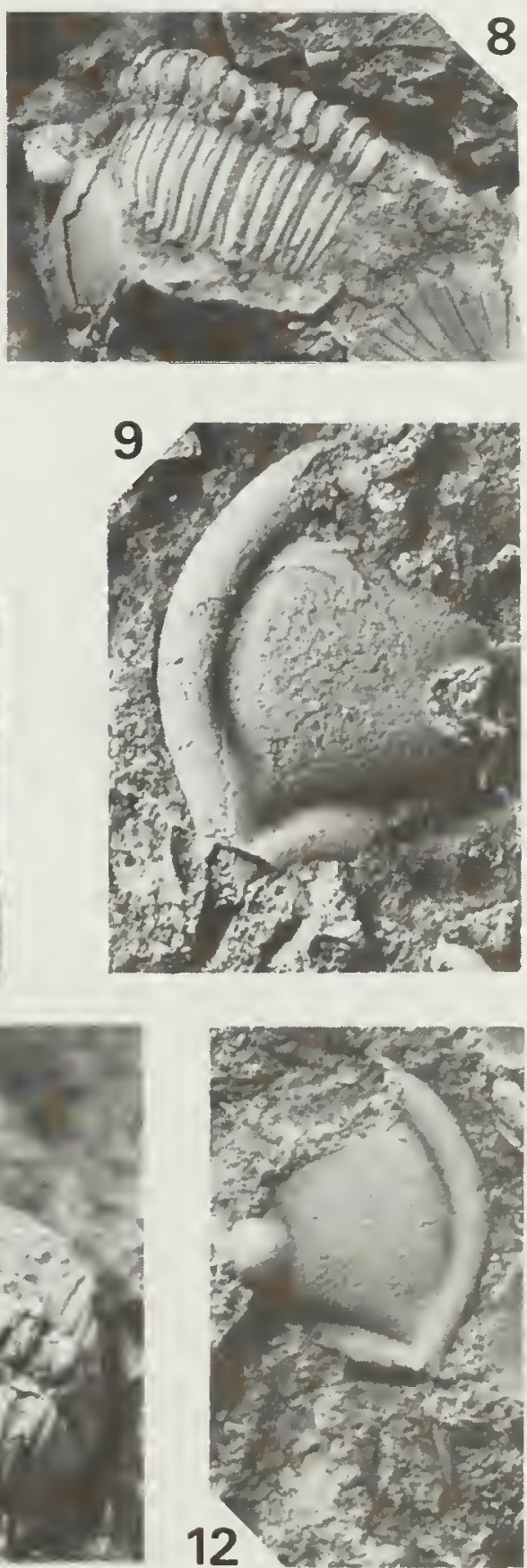
Plate 9, figs. 1-11.

All specimens are from locality BB 131, unnamed carbonates, Illtyd Range, Yukon Territory, Canada.

Figs. 1-3. Scotoharpes raaschi Norford, 1973.

1,3. Cephalon, dorsal and oblique views, ROM 42184, $\times 5$.

2. Cephalon, latex impression, dorsal view, ROM 42185, $\times 5$.

Figs. 4,5. Indeterminate proctid B.

4. Hypostome, ventral view, ROM 42186, $\times 5$.

5. Cranidium, dorsal view, ROM 42187, $\times 5$.

Fig. 6. Encrinuraspis sp., pygidium, dorsal view, ROM 42188, × 9 .

Fig. 7. Indeterminate calymenid, pygidium, dorsal view, ROM 42189, $\times 4$.

Figs. 8-11. Kosovopeltis? spp.

8. Pygidium, dorsal view, ROM 42190, $\times 5$.

9. Cranidium, dorsal view, ROM 42191, $\times 9$.

10. Pygidium, dorsal view, ROM 42192, $\times 4$.

11. Pygidium, dorsal view, ROM 42193, $\times 4$. 

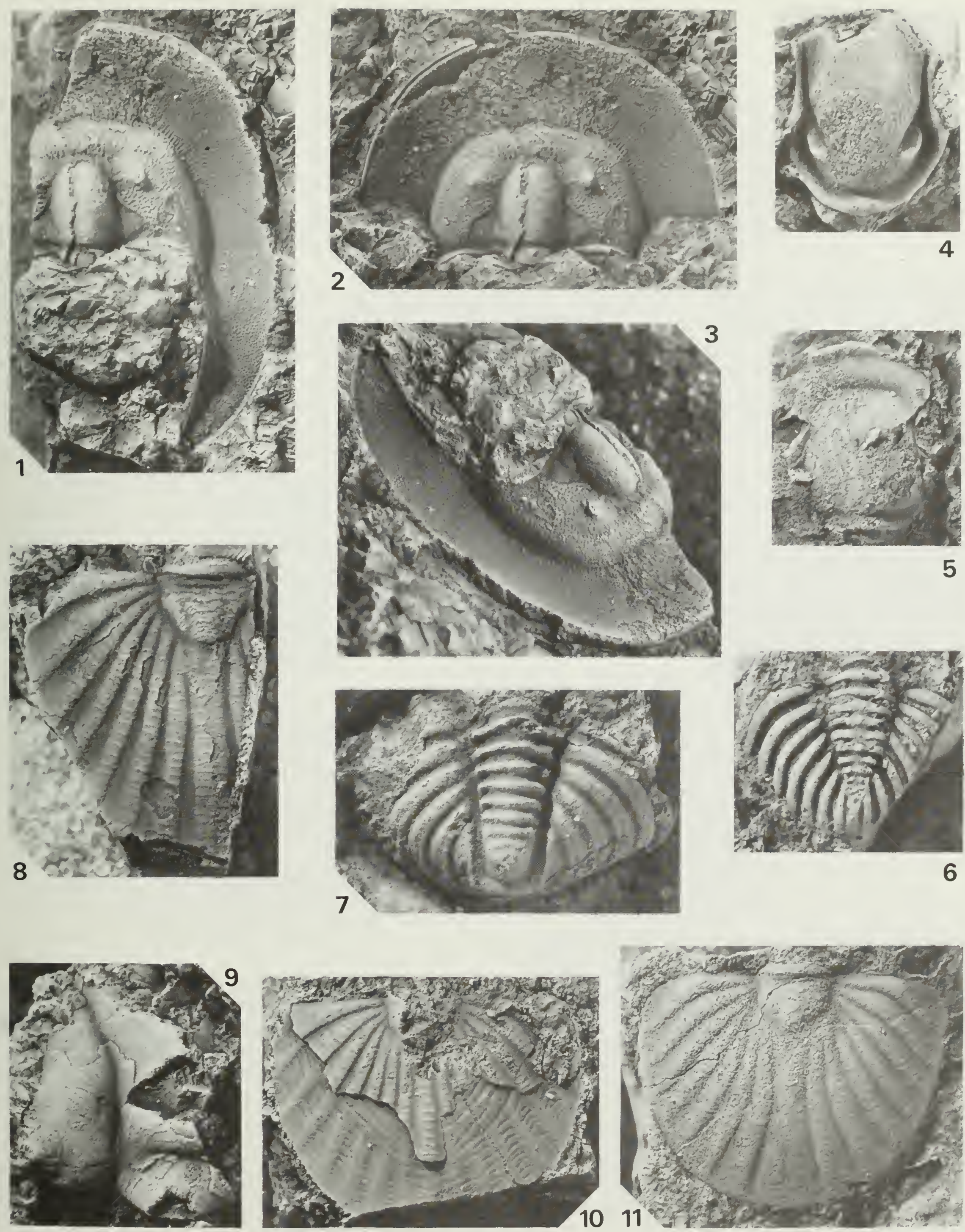
Plate 10, figs. 1-12.

Figs. 1-8. Cromus princeps (Poulsen), locality AA 2-4.5, Road River Formation, Prongs Creek, Yukon Territory, Canada.

1,2. Cranidium, oblique and dorsal views, ROM 42194, $\times 4$.

3. Hypostome, ventral view, ROM 42195, $\times 9$.

4. Librigena, oblique view, ROM 42196, $\times 5$.

5. Pygidium (deformed), dorsal view, ROM 42197, $\times 9$.

6. Cranidium, dorsal view, ROM 42198, $\times 9$.

7. Pygidium, dorsal view, ROM 42199, $\times 4$.

8. Pygidium, dorsal view, ROM 42200, $\times 4$.

Fig. 9. Indeterminate odontopleurine, locality BB 131, unnamed carbonates, Illtyd Range, Yukon Territory, Canada, cranidium, dorsal view, ROM 42201, $\times 9$.

Figs. 10-12. Dicranopeltis sp., locality BB 131, unnamed carbonates, Illtyd Range, Yukon Territory, Canada.

10,11. Cranidium, dorsal and oblique views, latex impression, ROM 42202, $\times 9$.

12. Pygidium, dorsal view, ROM 42203, $\times 9$. 

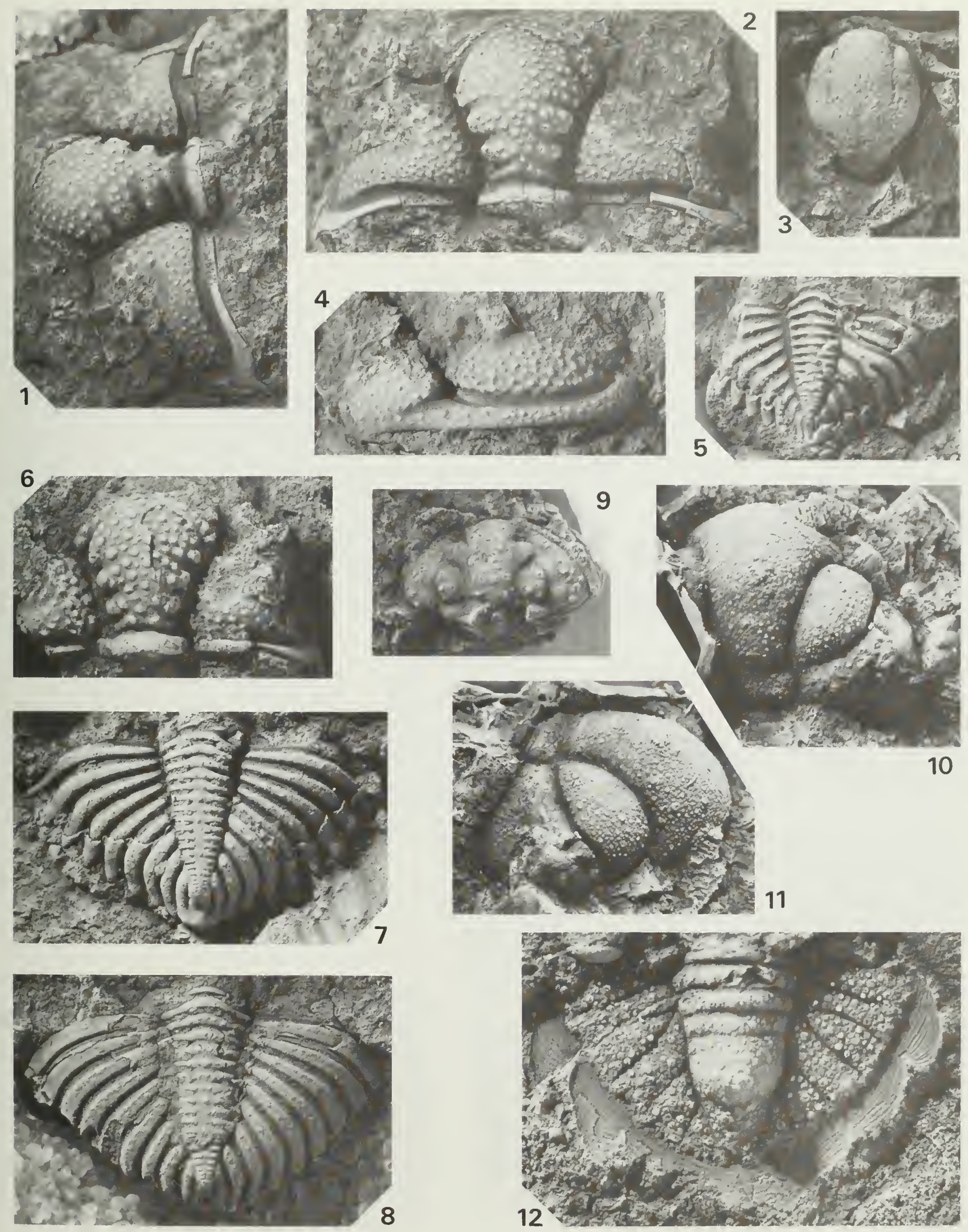
Plate 11, figs. 1-18.

Figs. 1-5. Paracybantyx asulcatus gen. et sp. nov., locality AA 95, Road River Formation, Prongs Creek, Yukon Territory, Canada.

1. Pygidium, dorsal view, $\mathrm{ROM} 45345, \times 2$.

2. Librigena, ventral view showing pit in doublure, $\mathrm{ROM} 45366 \mathrm{a}, \times 4$.

3. Librigena, latex impression, oblique view showing doublure, ROM 45352, $\times 4$.

4. Pygidial doublure, latex impression, ventral view, $\mathrm{ROM} 45374, \times 4$.

5. Pygidium, dorsal view, ROM $45369, \times 6$.

Figs. 6,7. Indeterminate scutelluine, locality AA 95, Road River Formation, Prongs Creek, Yukon Territory, Canada, cranidium, dorsal view, ROM 45359, $\times 4$ and $\times 8$.

Figs. 8-10, 12-18. Balizoma aff. B. obtusus (Angelin), locality AA 95, Road River Formation, Prongs Creek, Yukon Territory, Canada.

8. Pygidium, dorsal view, ROM 45325, $\times 6$.

9,10. Pygidium, latex impression, oblique and dorsal views, ROM 45350, $\times 4$.

12. Cranidium, dorsal view, ROM $45336 \mathrm{~b}, \times 4$.

13,14. Pygidium, dorsal and lateral views, ROM 45324, $\times 4$.

15,16. Pygidium, posterior and dorsal views, ROM 45367, $\times 4$.

17,18. Hypostome, oblique and ventral views, ROM 45362, $\times 6$.

Fig. 11. Indeterminate encrinurine, locality AA 95, Road River Formation, Prongs Creek, Yukon Territory, Canada, cranidium, dorsal view, ROM 45373, × 3 . 

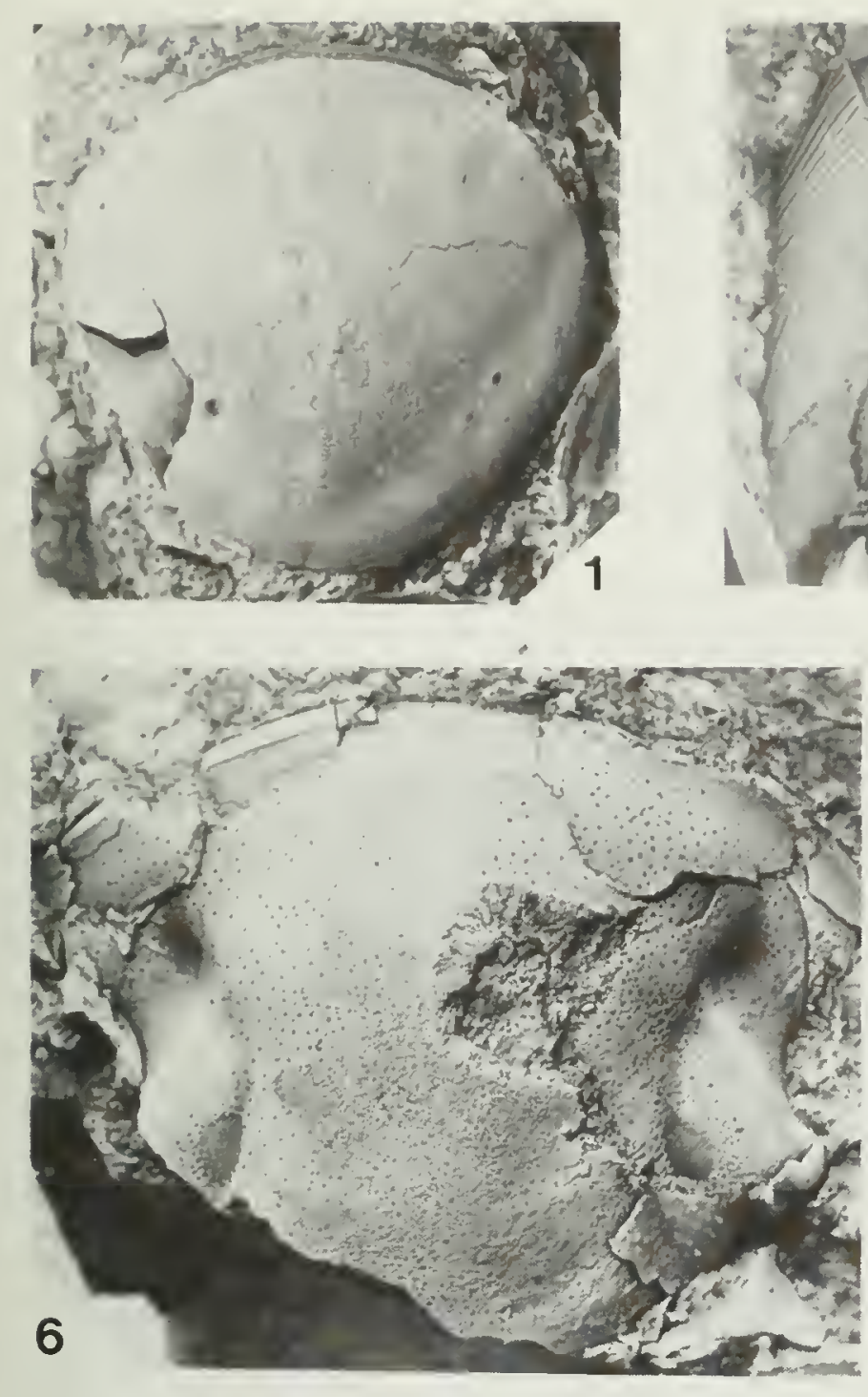
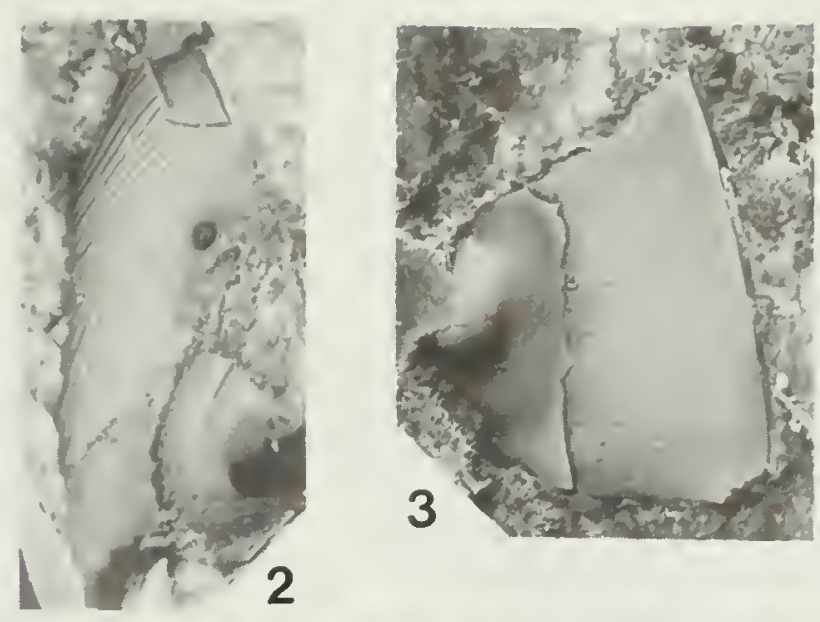
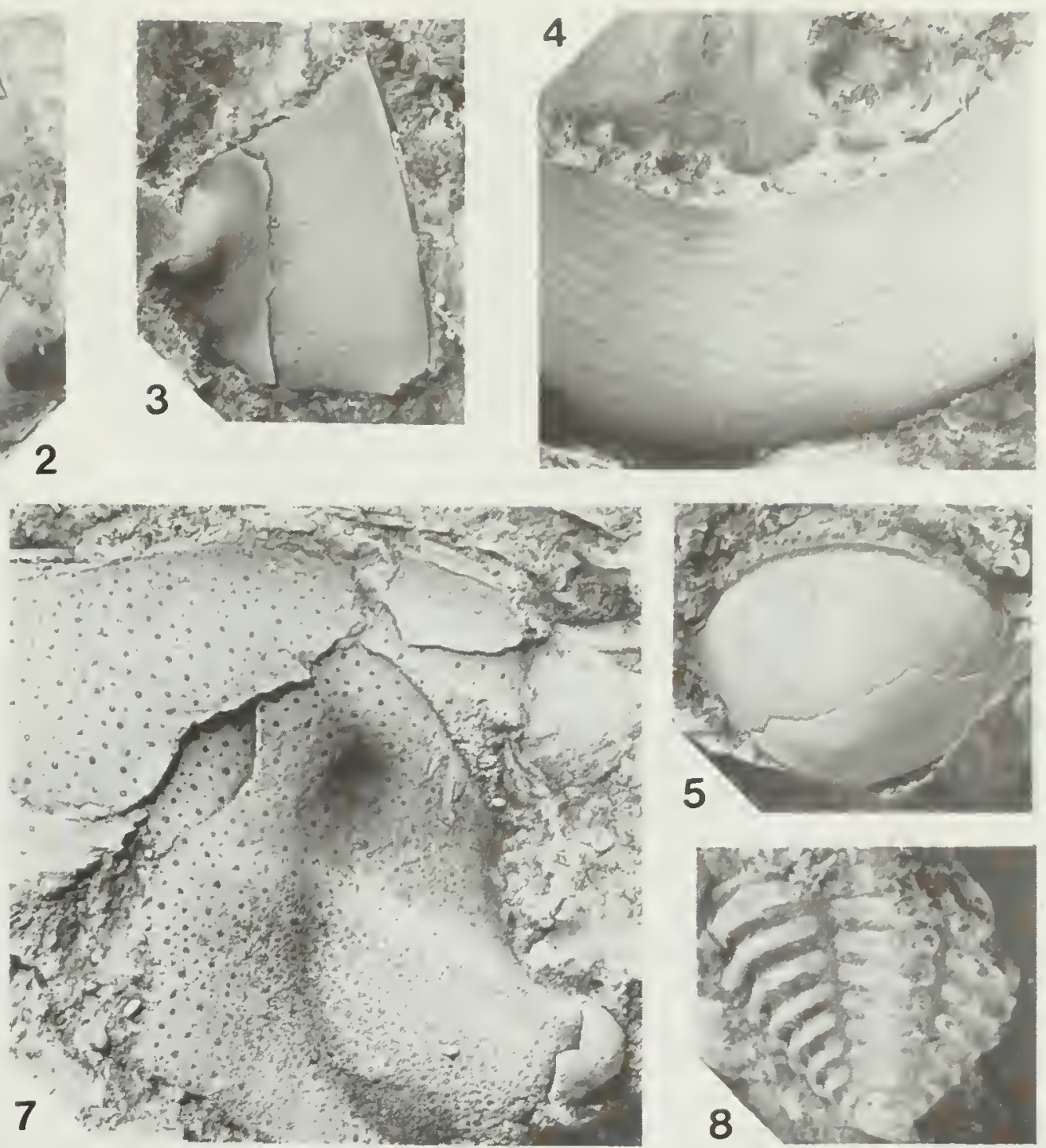

11

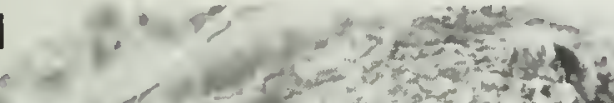
2. F. 5.

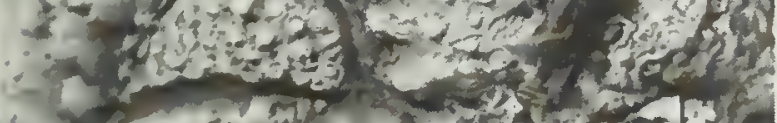

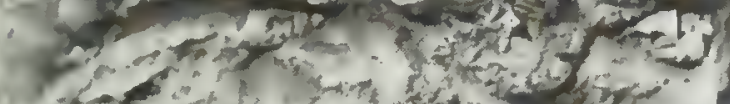
$25,2+3$

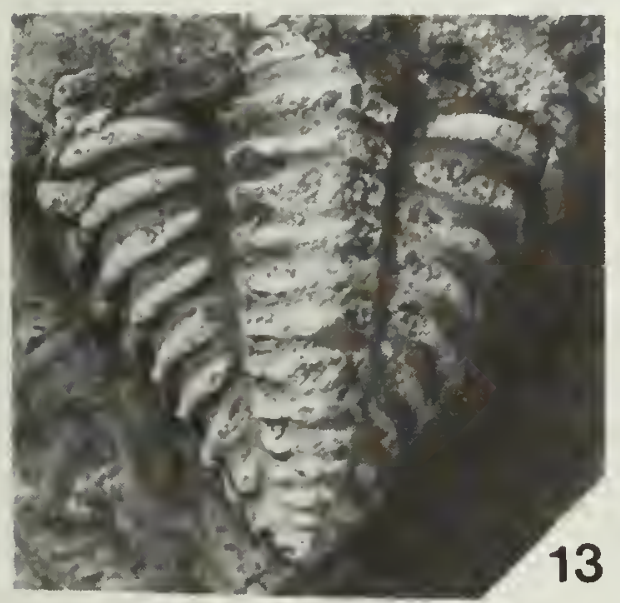

12
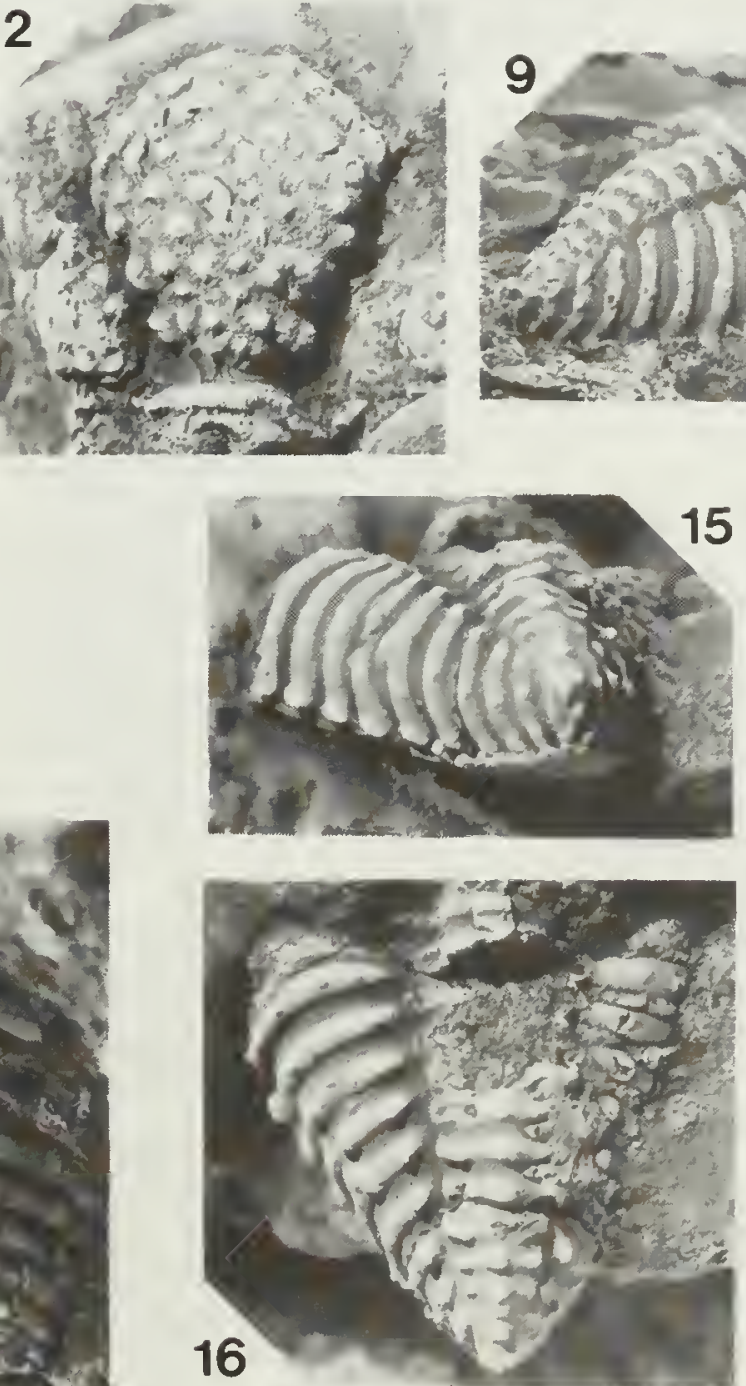
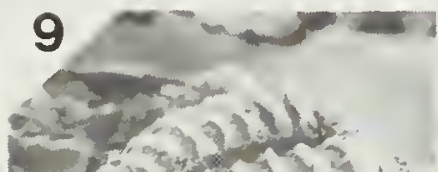

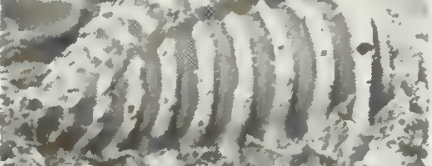

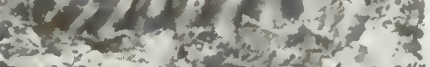
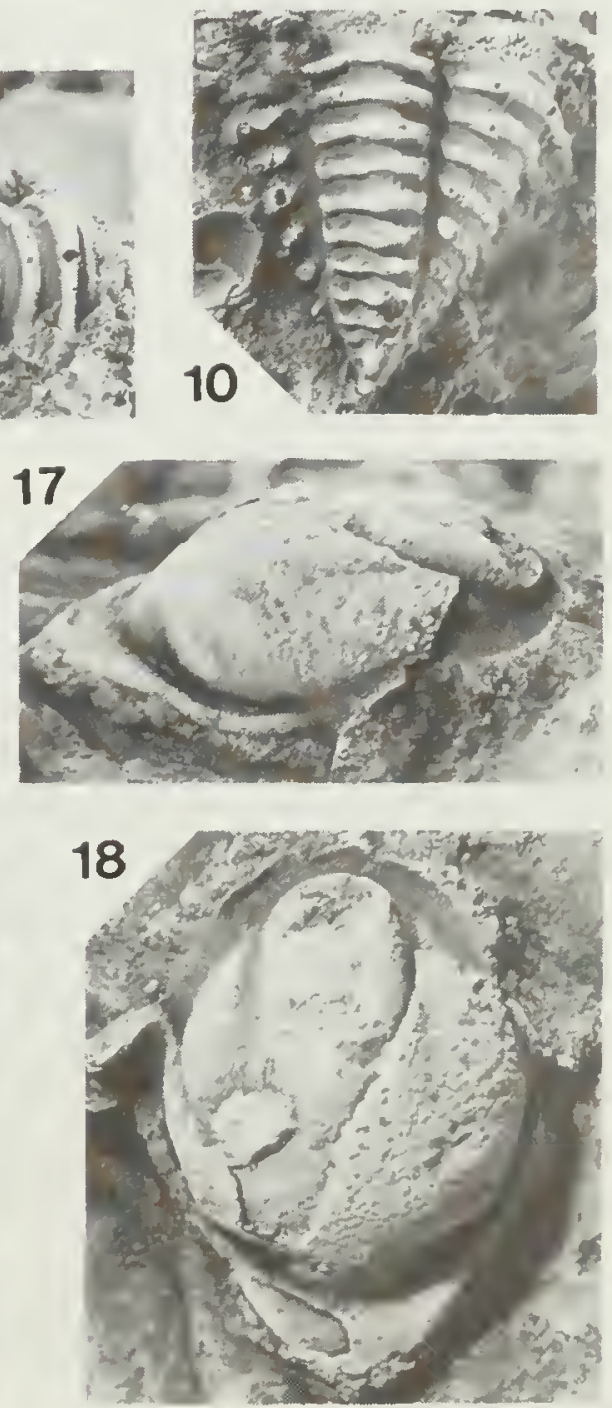
Plate 12, figs. 1-16.

Figs. 1-13. Leonaspis semiglabra (Poulsen), locality AA 2-4.5, Road River Formation, Prongs Creek, Yukon Territory, Canada.

1. Cranidium, latex impression, dorsal view, $\mathrm{ROM} 42205, \times 9$.

2. Hypostome, ventral view, ROM 42206, $\times 9$.

3. Pygidium, dorsal view, ROM 42207, $\times 9$.

4. Cranidium, latex impression, dorsal view, ROM 42208, $\times 9$.

5. Cranidium, latex impression, dorsal view, GSC 15399, $\times 9$.

6. Cranidium, latex impression, dorsal view, GSC 15398, $\times 9$.

7. Cranidium, latex impression, dorsal view, ROM 42209, $\times 9$.

8. Pygidium, dorsal view, GSC $15700, \times 9$.

9. Pygidium, dorsal view, GSC $15701, \times 9$.

10. Pygidium, dorsal view, ROM $42210, \times 9$.

11. Librigena, oblique view, ROM 42211, $\times 9$.

12. Pygidium, dorsal view, ROM 42212, $\times 9$.

13. Incomplete specimen, dorsal view, ROM 42213, $\times 6$.

Figs. 14-16. Otarion (Songkania) socialis (Poulsen), locality AA 2-4.5, Road River Formation, Prongs Creek, Yukon Territory, Canada.

14. Cranidium, dorsal view, GSC $15392, \times 9$.

15. Pygidium, dorsal view, ROM 42214, $\times 9$.

16. Pygidium, dorsal view, GSC $15393, \times 9$. 


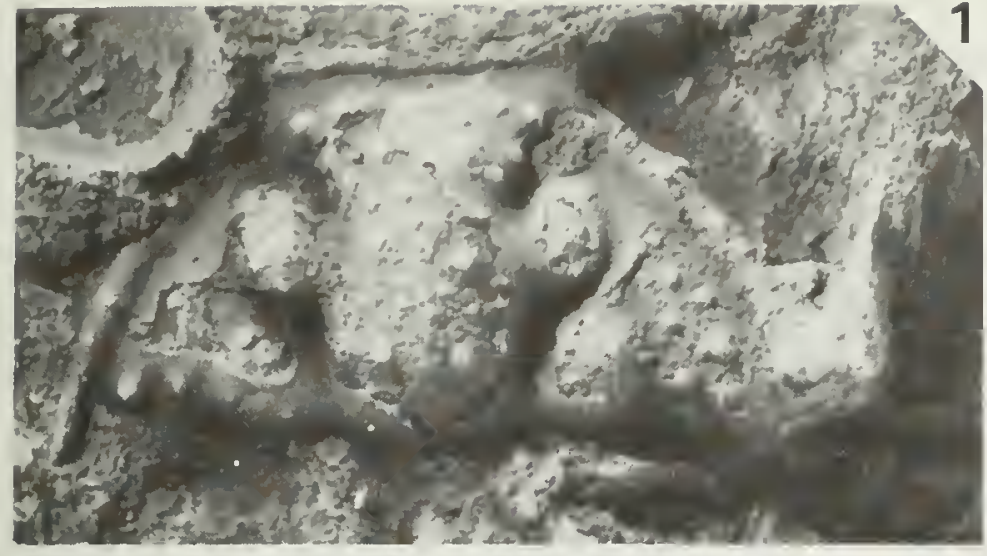

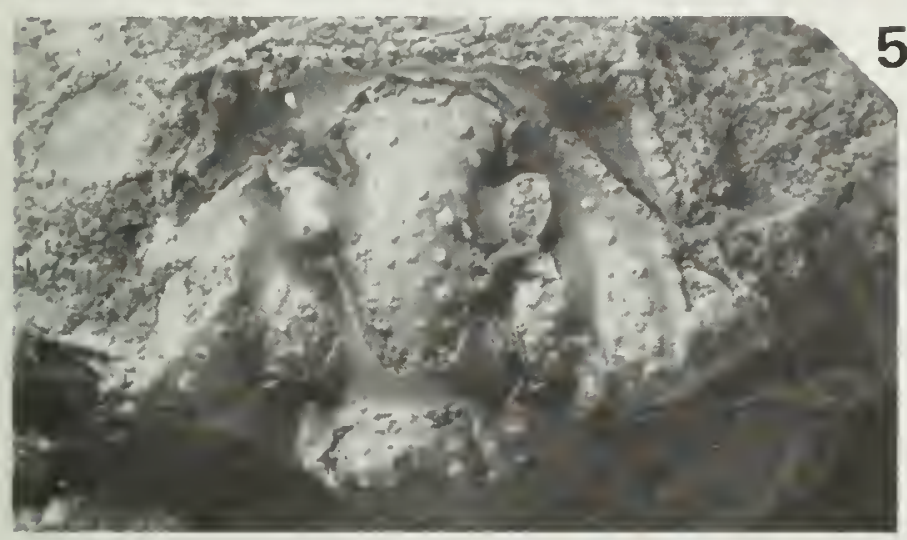
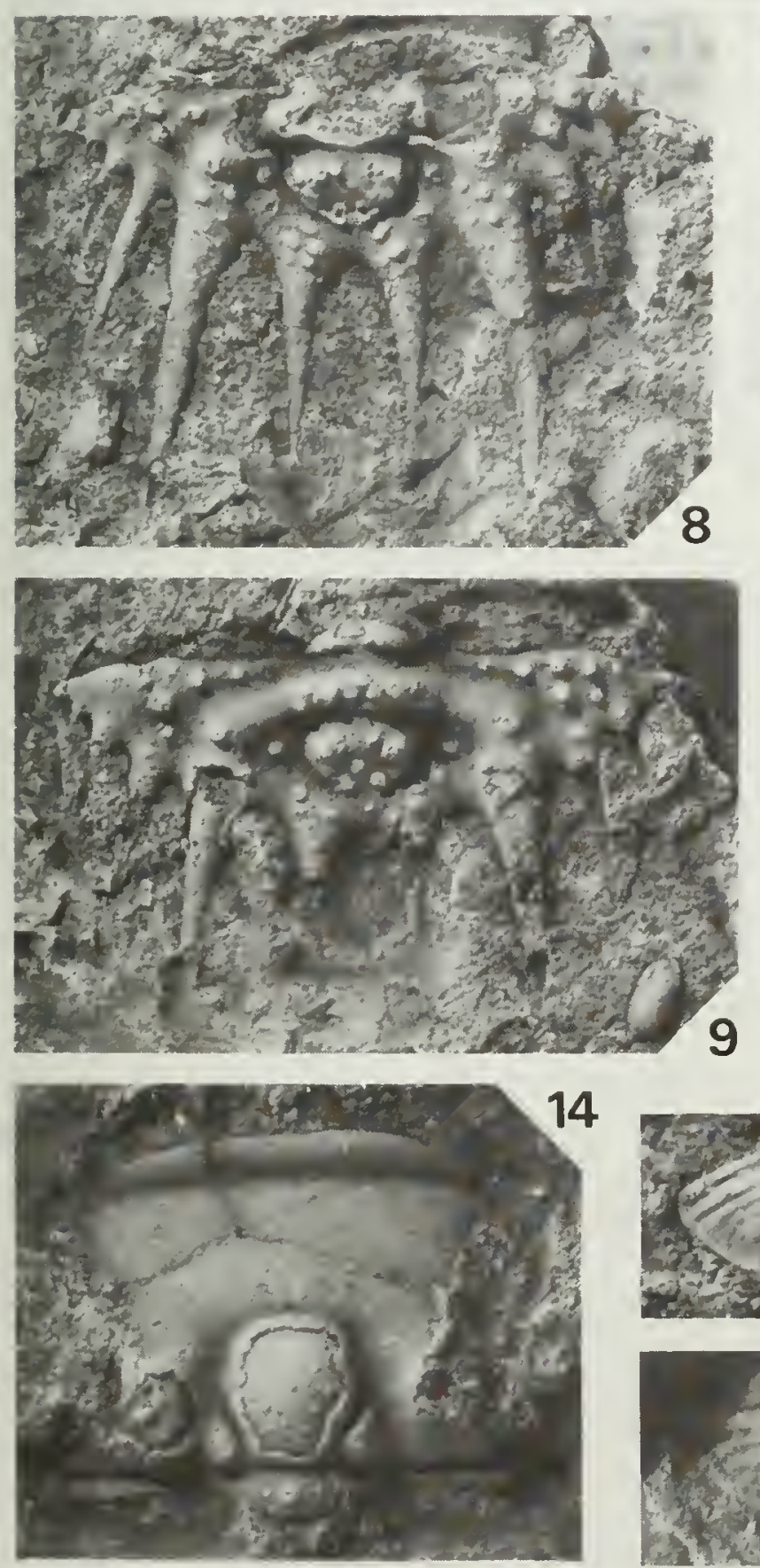

14
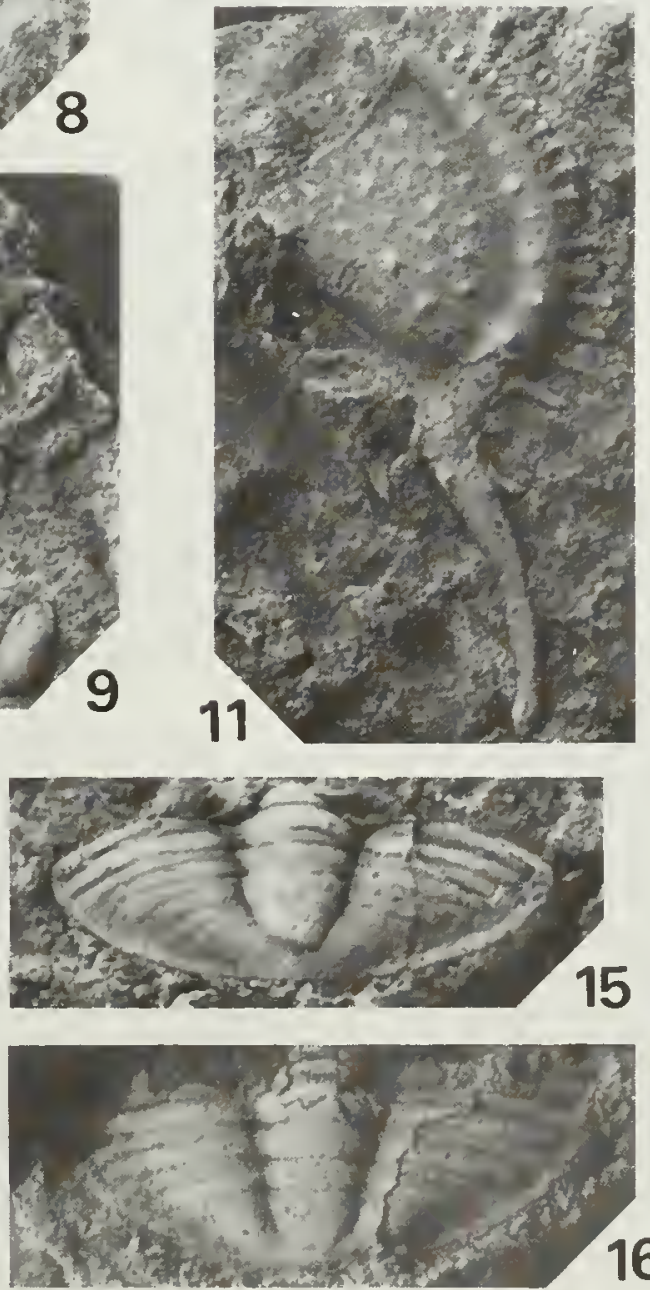
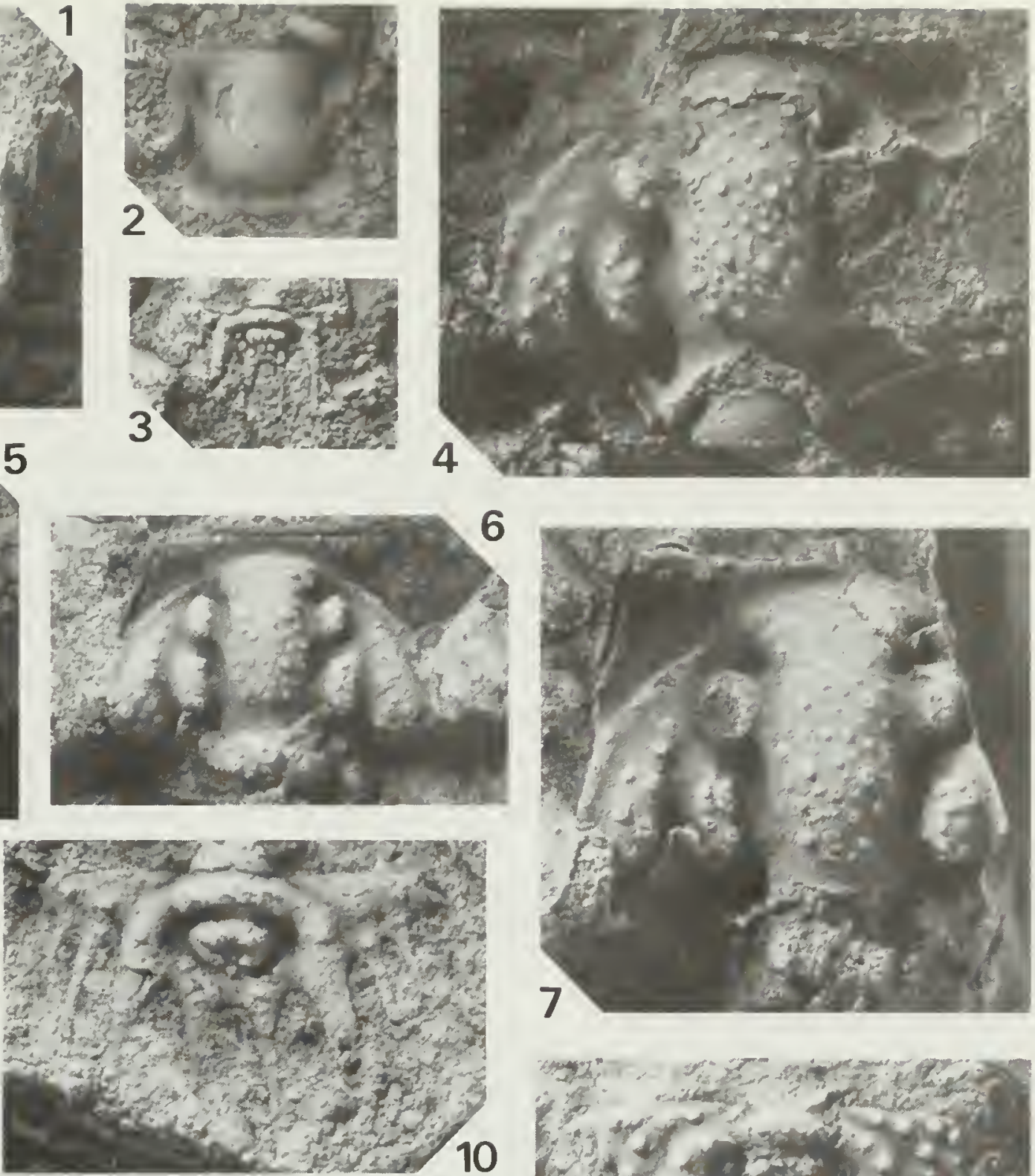

10

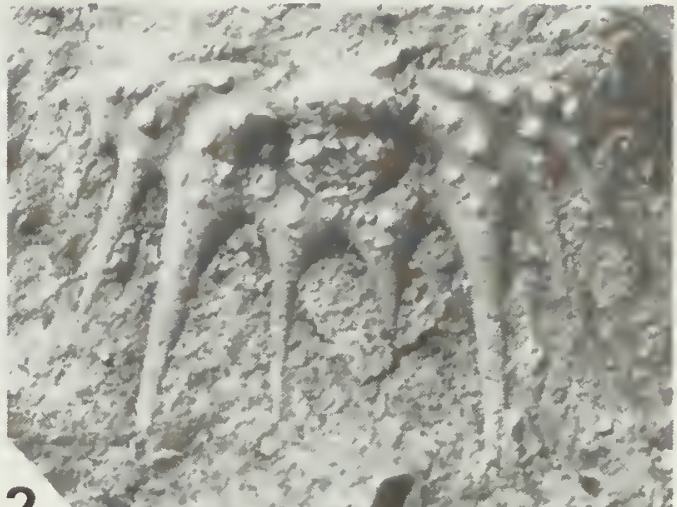

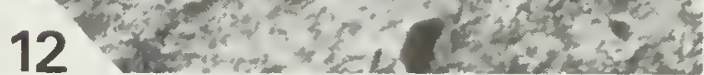

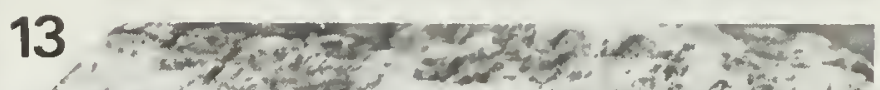
rin

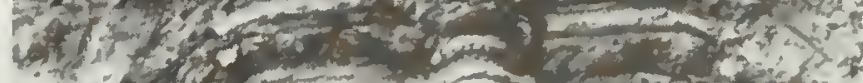

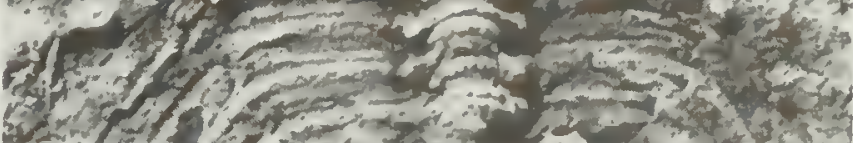

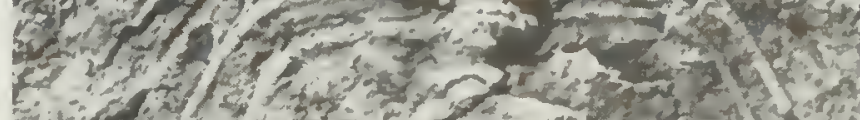

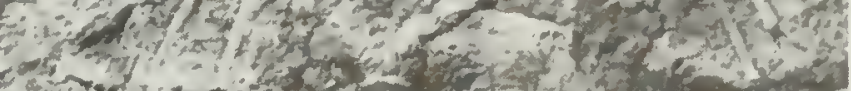

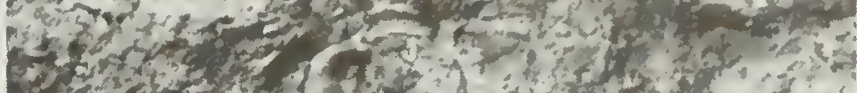

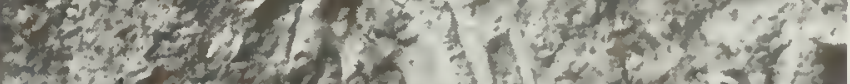


Plate 13, figs. 1-14.

Figs. 1,2. Kosovopeltis borealis (Poulsen), Cape Schuchert Formation of Poulsen (1934), Kap Schuchert, North Greenland.

1. Holotype cranidium, dorsal view, MMH $3267, \times 3$.

2. Cranidium, dorsal view, MMH 3268, $\times 3$.

Figs. 3-6. Otarion (Songkania) socialis (Poulsen), Cape Schuchert Formation, Kap Schuchert, North Greenland.

3,4. Holotype cranidium, dorsal and anterior views, MMH 3251, $\times 9$. Note caecae crossing preglabellar field abaxially.

5. Librigena, oblique view, MMH 3252, $\times 6$.

6. Pygidium, dorsal view, MMH 3253, $\times 9$.

Figs. 7-12. Cromus princeps (Poulsen), Cape Schuchert Formation, Kap Schuchert, North Greenland.

7. Pygidium, dorsal view, MMH 3278, $\times 3$.

8. Pygidium, dorsal view, MMH 3279, $\times 3$.

9. Pygidium, dorsal view, MMH 3280, $\times 3$.

10,11. Holotype cranidium, dorsal and oblique views, MMH 3276, $\times 4$.

12. Librigena, oblique view, MMH 3277, $\times 3$.

Figs. 13,14. Leonaspis semiglabra (Poulsen), Cape Schuchert Formation, Kap Schuchert, North Greenland.

13. Holotype cranidium, dorsal view, MMH 3261, $\times 9$.

14. Librigena, oblique view, attributed to L. groenlandica by Poulsen, MMH 3258, $\times 9$. 

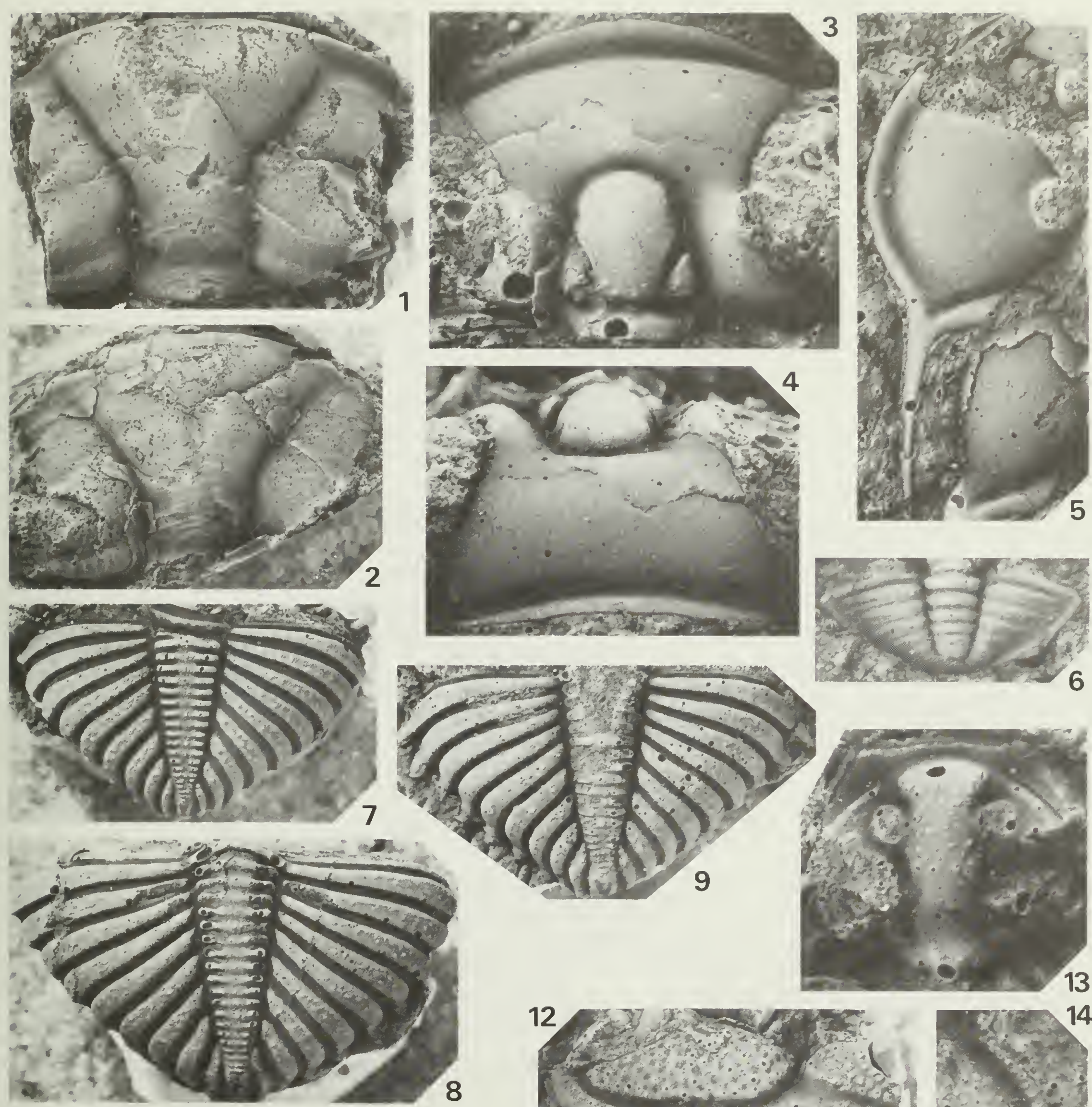

10

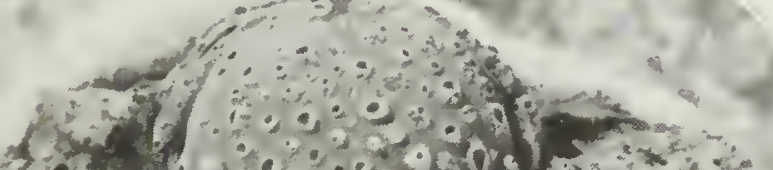

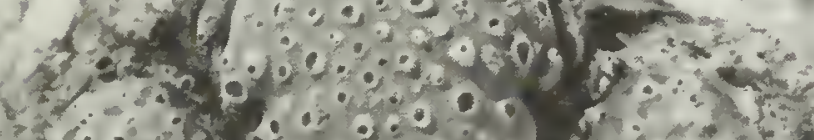
$10\{\therefore 300000$ \& 01

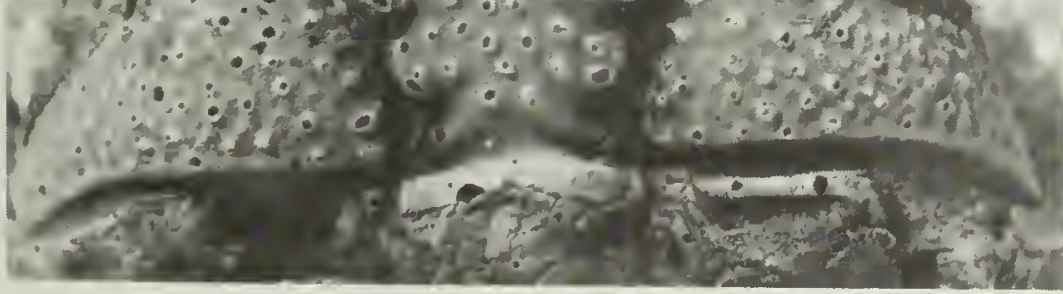

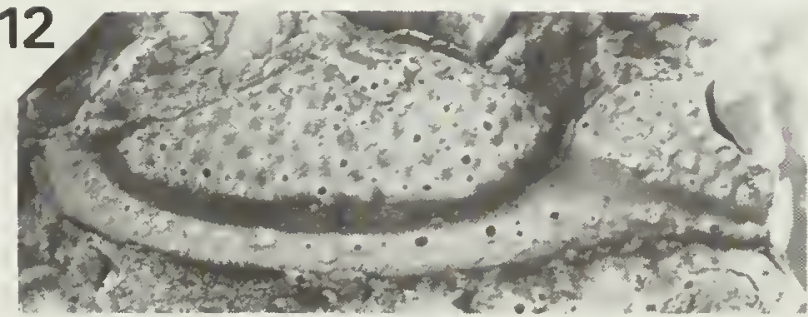
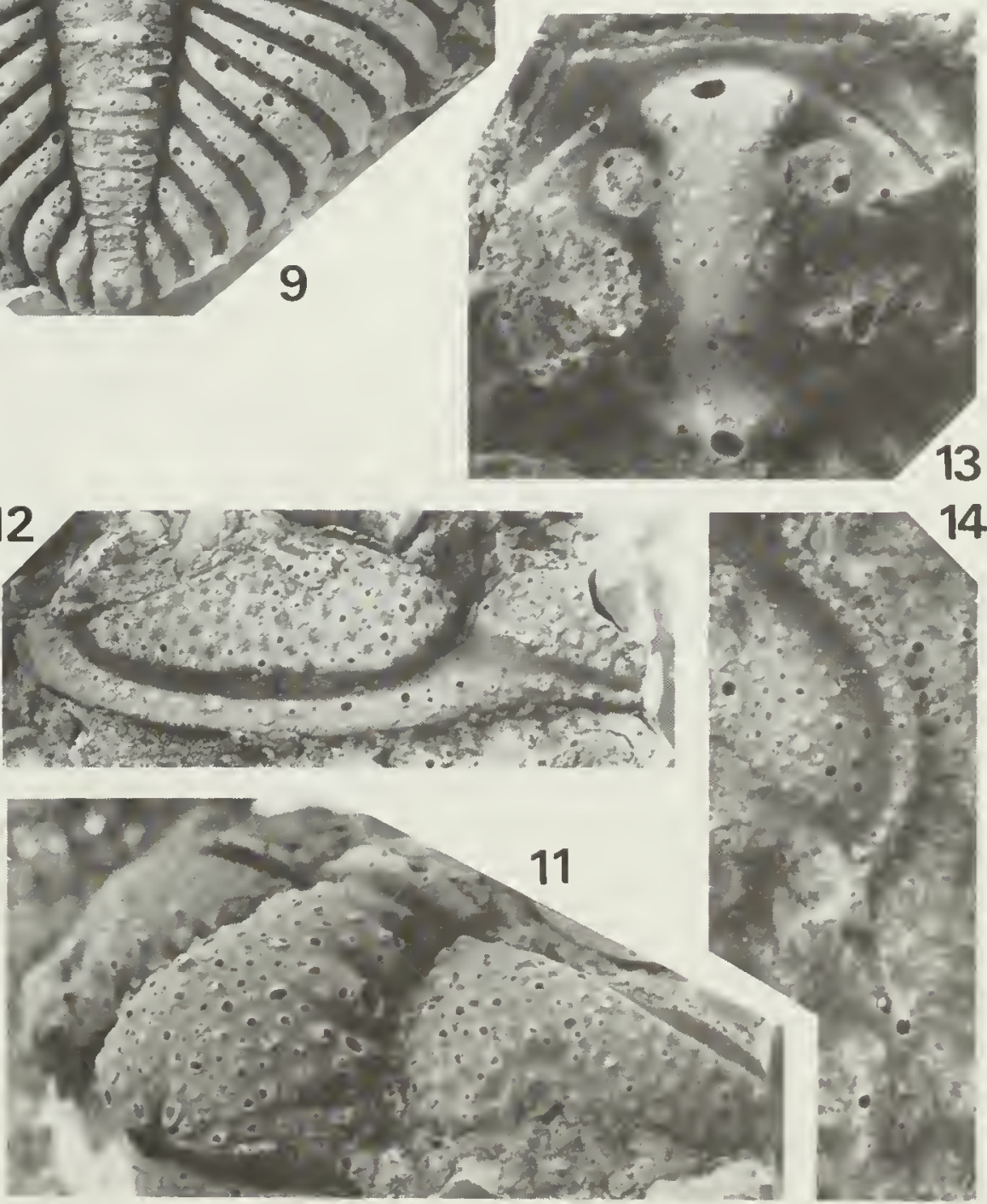

Life Sciences Contributions are a numbered series of scientific publications of varied subject matter published by the Royal Ontario Museum. Most recent contributions include:

145 An Annotated Checklist of the Fishes of the Chagos Archipelago, Central Indian Ocean Richard Winterbottom, Alan R. Emery, and Erling Holm 1989, 226 pp., ill., \$48.50, ISBN 0-88854-329-8

146 Stipatocrinus, a New and Unusual Camerate Crinoid from the Lower Silurian of Western New York James D. Eckert and Carlton E. Brett 1987, 17 pp., ill., \$6.00, ISBN 0-88854-336-0

147 Biostratigraphy and Palaeontology of the Scollard Formation, Late Cretaceous and Paleocene of Alberta Loris S. Russell 1987, 23 pp., ill., \$7.00, ISBN 0-88854-338-7

148 Shallow-Water Hydroids of Bermuda: The Athecatae Dale R. Calder 1988, 107 pp., ill., \$24.50, ISBN 0-88854-339-5

149 Occurrence of the Cladid Inadunate Crinoid Thalamocrinus in the Silurian (Wenlockian) of New York and Ontario George C. McIntosh and Carlton E. Brett 1988, 17 pp., ill., \$7.75, ISBN 0-88854-342-5

150 Late Cretaceous-Early Tertiary Dinoflagellates and Acritarchs from the Kashi Area, Tarim Basin, Xinjiang Province, China Mao Shaozhi and Geoffrey Norris 1988, 93 pp., ill., \$23.00, ISBN 0-88854-334-4

151 The Structure of the Call Note System of the Warbling Vireo Daryl Howes-Jones and Jon C. Barlow 1988, 36 pp., ill., \$10.25, ISBN 0-88854-343-3

152 The Type Species of the Ordovician Trilobite Genus Isotelus: I. gigas Dekay, 1824

David M. Rudkin and Ronald P. Tripp

1989, 19 pp., ill., \$10.25, ISBN 0-88854-345-X

The Royal Ontario Museum also publishes Life Sciences Miscellaneous Publications and Life Sciences Occasional Papers.

A complete catalogue of publications in print is available from:

Publication Services

Royal Ontario Museum

100 Queen's Park

Toronto, Ontario

Canada M5S 2C6

(416) $586-5581$

Fax (416) 586-5863

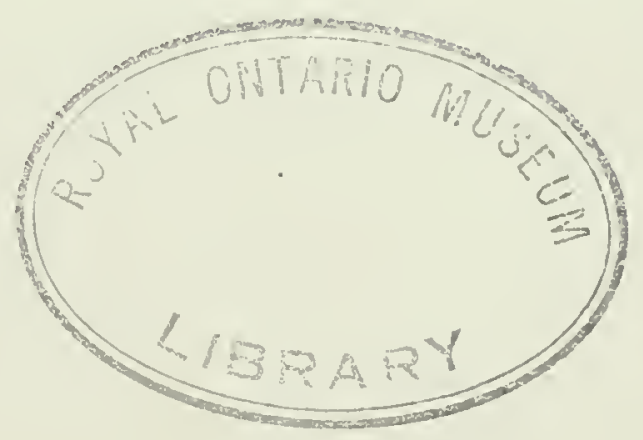




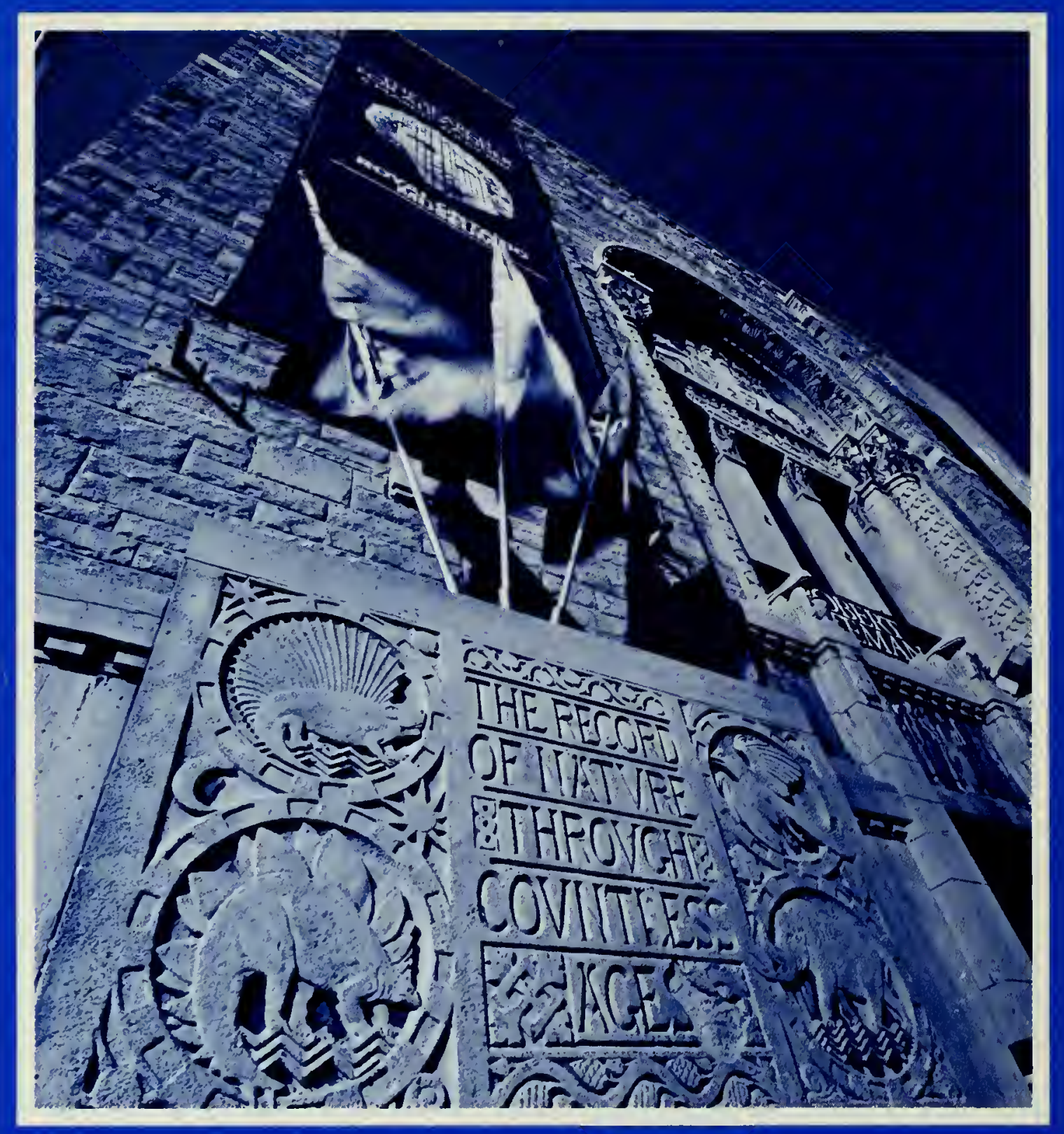

ISBN 0-88854-349-2

ISSN 0384-8159 